\title{
Sprouts and Microgreens: Trends, Opportunities, and Horizons for Novel Research
}

\author{
Angelica Galieni ${ }^{1}$, Beatrice Falcinelli ${ }^{2}$, Fabio Stagnari ${ }^{3}$, Alessandro Datti ${ }^{2, *}$ \\ and Paolo Benincasa 2 (D) \\ 1 Council for Agricultural Research and Economics, Research Centre for Vegetable and Ornamental Crops, \\ Via Salaria 1, 63030 Monsampolo del Tronto (AP), Italy; angelica.galieni@crea.gov.it \\ 2 Department of Agricultural, Food, and Environmental Sciences, University of Perugia, Borgo XX Giugno 74, \\ 06121 Perugia, Italy; beatricefalcinelli90@gmail.com (B.F.); paolo.benincasa@unipg.it (P.B.) \\ 3 Faculty of Bioscience and Technologies for Food, Agriculture and Environment, University of Teramo, \\ Campus Universitario di Coste Sant'Agostino, via R. Balzarini 1, 64100 Teramo, Italy; fstagnari@unite.it \\ * Correspondence: alessandro.datti@unipg.it
}

Received: 27 August 2020; Accepted: 15 September 2020; Published: 19 September 2020

\begin{abstract}
Sprouts and microgreens have attracted tremendous interest across multiple disciplines in recent years. Here, we critically review the most recent advances to underscore research prospects and niches, and related challenges, not yet addressed or fully pursued. In particular, we report a number of themes that merit special attention as a result of their relevance to plant science, nutrition, health, and zootechnics: (1) species not yet or inadequately investigated, such as wild plants, and fruit tree strains; (2) abiotic and biotic factors, and biostimulants, for elicitation strategies and metabolic engineering; (3) sanitization and processing technologies to obtain high-quality products; (4) digestive fate and impact of bioactive elements, antinutrients, and allergens on human nutrition; (5) experimental challenges to researching health benefits; (6) the opportunity to generate natural product libraries for drug discovery; and (7) sprouts in animal feeding to improve both animal health and the nutritional value of animal products for the human diet. The convergence of different themes involving interdisciplinary competencies advocate fascinating research pursuits, for example, the elicitation of metabolic variants to generate natural product collections for identification and selection of bioactive chemicals with a role as nutraceuticals, key constituents of functional foods, or interactive partners of specific drugs.
\end{abstract}

Keywords: plant; elicitation; post-harvest; food safety; human nutrition; functional foods; nutraceuticals; drug; human health; animal feeding

\section{Introduction}

In recent years, microscale vegetables have become increasingly popular for homemade food preparations and have been the subject of progressively higher interest by the ready-to-eat market and the dietary supplements industry. While this trend is true for a vast variety of young plants and their constituents [1-3], this review is centered on sprouted seeds and microgreens, namely, shoots with fully expanded cotyledons, including grasses (i.e., shoots of Poaceae) [4]. 
Sprouts and microgreens can be produced quickly, easily, and cost-effectively due to simple requirements for equipment and supplies, and a rapid developmental process varying from a few days (sprouts) to approximately two weeks (microgreens). This, in turn, suggests a unique opportunity for industrial scalability coupled with the prospect for consumers to independently access food with proven or purported nutritional benefits $[5,6]$. Compared to seeds or mature plants, both sprouts and microgreens are known to contain low amounts of antinutrients, while being rich in amino acids, fatty acids, and simple sugars as a result of enzymatic breakdown of large macromolecules, and bioactive compounds, namely, a cohort of secondary metabolites, also known as phytochemicals [4,7-10].

Most phytochemicals are low-molecular-weight and anti-microbial compounds synthesized de novo (i.e., phytoalexins) or from existing precursors (i.e., phytoanticipins) [11,12]. Among phytoanticipins, glucosinolates are commonly found in Brassicaceae sprouts, and among phytoalexins, terpenoids and phenolic compounds are widespread in sprouts of most plant species. Their high concentration in seedlings contributes to increased vigor and tolerance to any stress potentially occurring in early stages of development Table 1.

Table 1. Main functions recognized to the principal phytochemical classes and subclasses.

\begin{tabular}{|c|c|c|c|}
\hline Class & & Function in Plants & References \\
\hline \multirow{4}{*}{ Polyphenols } & Flavonoids & $\begin{array}{l}\text { Pigments (i.e., anthocyanins, flavanols, and flavones); } \\
\text { UV protection (i.e., flavones and flavonols); } \\
\text { scavenger of } \mathrm{H}_{2} \mathrm{O}_{2} \text {, superoxide, hydroxyl radical, singlet oxygen, } \\
\text { peroxyl radical; } \\
\text { feeding and wounding deterrents (i.e., hydrolyzable tannins); } \\
\text { insecticidal and antimicrobial action (i.e., isoflavones). }\end{array}$ & [13-15] \\
\hline & Phenolic acids & $\begin{array}{l}\text { Plant-microbe symbiosis; } \\
\text { allelopathic effect (caffeic and ferulic acid); } \\
\text { feeding deterrents as astringent compounds (i.e., condensed tannins); } \\
\text { resistance to pathogen attack; } \\
\text { components of cell-wall; } \\
\text { attract pollinators and seed dispersers; } \\
\text { signaling molecules (i.e., salicylic acid). }\end{array}$ & {$[14,15]$} \\
\hline & Stilbenes & $\begin{array}{l}\text { Defensive response to pathogens or stress conditions; } \\
\text { protective agents from viral and microbial attack, injuries, diseases, UV } \\
\text { exposure, aluminum, etc. }\end{array}$ & {$[15,16]$} \\
\hline & Lignans & $\begin{array}{l}\text { Building blocks for the fiber lignin; } \\
\text { plant defense diseases and pests. }\end{array}$ & {$[15,17]$} \\
\hline \multirow{3}{*}{ Terpenoids } & Overall & $\begin{array}{l}\text { Plant growth regulators; } \\
\text { defense against herbivores and pathogens; } \\
\text { attracting pollinators influence the growth and the development of } \\
\text { neighbor plant. }\end{array}$ & {$[13,18]$} \\
\hline & Carotenoids & $\begin{array}{l}\text { Pigments; } \\
\text { protection against photooxidation; } \\
\text { light-harvesting pigments. }\end{array}$ & {$[13,14]$} \\
\hline & Tocotrienols and tocopherols & $\begin{array}{l}\text { Singlet oxygen scavengers in photosystem ii; } \\
\text { signaling molecules; } \\
\text { maintain the integrity of long-chain polyunsaturated fatty acids in } \\
\text { the cell membranes. }\end{array}$ & [19] \\
\hline$N$-containing metabolites & Glucosinolates & $\begin{array}{l}\text { Herbivore toxins and feeding repellents; } \\
\text { insects deterrents and pathogens growth inhibitors (isothiocyanates). }\end{array}$ & {$[12-14,20]$} \\
\hline
\end{tabular}

Notably, a large array of phytochemicals exhibit antioxidant properties, and, in many instances, the presence of phytochemicals in the diet has been shown to provide beneficial effects to human health; Table 2. 
Table 2. Phytochemicals and health benefits.

\begin{tabular}{|c|c|c|c|}
\hline Chemical Class & Subclass & Health Benefits & References \\
\hline \multirow{4}{*}{ Polyphenols } & Flavonoids & $\begin{array}{l}\text { Antioxidants: long-lived radical anions scavengers; } \\
\text { anti-lipoperoxidant, -tumoral, -platelet, ischemic, -allergic, } \\
\text {-inflammatory activities. }\end{array}$ & [21] \\
\hline & Phenolic acids & $\begin{array}{l}\text { Radical scavengers; } \\
\text { singlet oxygen quenching; } \\
\text { block biosynthesis of leukotrienes involved in immunoregulation } \\
\text { disease, asthma and allergic reaction (caffeic acid). }\end{array}$ & [21] \\
\hline & Stilbenes & $\begin{array}{l}\text { Anti-oxidative, -carcinogenic, -tumor properties; retard cardiovascular } \\
\text { disease and cancer; } \\
\text { prevent lipid oxidation and the formation of toxic oxidation products. }\end{array}$ & [21] \\
\hline & $\begin{array}{l}\text { Phytoestrogens (i.e., isoflavones, } \\
\text { lignans, coumestans) }\end{array}$ & $\begin{array}{l}\text { Prevent menopausal symptoms (hot-flashes, vasomotor symptoms, } \\
\text { vaginal atrophy); } \\
\text { anti-aging effect on the skin; } \\
\text { enhance bone formation and increase bone mineral density; } \\
\text { beneficial effects on endothelial cells, vascular smooth muscle; } \\
\text { reduce levels of low-density lipoprotein (LDL) cholesterol; } \\
\text { anti-mutagenic, -proliferative, -angiogenic, pro-apoptotic and general } \\
\text { anti-cancer effects. }\end{array}$ & [22] \\
\hline \multirow{3}{*}{ Terpenoids } & Carotenoids & $\begin{array}{l}\text { Chemical quenchers of }{ }^{1} \mathrm{O}_{2} \\
\text { reduce the risk of prostate cancer and age-related macular degeneration; } \\
\text { stimulate the immune system in inflammatory diseases or human } \\
\text { immunodeficiency disease. }\end{array}$ & [23] \\
\hline & Tocotrienols and tocopherols & $\begin{array}{l}\text { Retard cancer lesions and tumors; } \\
\text { tackle free radical reactions; } \\
\text { scavengers of lipid peroxyl radicals; } \\
\text { singlet oxygen quenchers. }\end{array}$ & [23] \\
\hline & Phytosterols & $\begin{array}{l}\text { Reduce cholesterol levels; } \\
\text { attenuate inflammatory processes; } \\
\text { induce apoptosis when added to cultured human prostate, breast, } \\
\text { and colon cancer cells. }\end{array}$ & [24] \\
\hline$N$-containing metabolites & Glucosinolates & $\begin{array}{l}\text { Protect against Helicobacter pylori infections, light-induced damage of } \\
\text { retina brain ischemia/reperfusion, traumatic brain injury, intracerebral } \\
\text { hemorrhage, and contusion spinal cord injury (sulforaphane); } \\
\text { decrease infarct size, brain (or spinal cord) edema, and cortical } \\
\text { apoptosis (sulforaphane); } \\
\text { restoration of skin integrity; } \\
\text { inhibit growth of human tumor cells. }\end{array}$ & [25] \\
\hline
\end{tabular}

In the last decade, the scientific literature on sprouts has dramatically increased and has been widely reviewed $[1-4,23,26]$. Nonetheless, there are aspects that have been scarcely or never explored. These gaps in knowledge offer perspectives for multidisciplinary studies involving collaboration across competencies in plant biology, food science and technology, human and animal nutrition, pharmacology, and medicine. This review is aimed at identifying intriguing areas of investigation that merit special attention.

\section{Plant Species Scarcely Studied for Sprouting: Limits and Opportunities}

Plant species in the Poaceae, Brassicaceae, and Fabaceae families are most exploited for sprouting purposes and therefore most reported by the scientific literature. For these species, research has provided a lot of information on the nutritional traits of sprouts and microgreens [3,4,27].

Other cultivated species are used for sprouting, being appreciated for several peculiar traits: vivid colors (i.e., red for red basil; green for spinach), intense smells (i.e., aromatic herbs), pleasant textures (i.e., regular for Asteraceae; juicy for sunflower and beet; crunchy for celery), and variable tastes (i.e., regular for Asteraceae; slightly sour for beet; bitter for Cucurbitaceae) [3,5]. In this regard, the definition and quantification of organoleptic traits represent a subject still unexplored, even for the species commonly used for sprouting, borrowing the methodology and technology used for vegetables and fruits, such as the gas chromatography-olfactometry. A first preliminary work on this has been carried out by Bianchi et al. [28] to analyze taste quality traits and volatile profile in sprouts and wheatgrass of Triticum spp. Another recent study compared 12 microgreens in terms of sensory attributes and visual appearance, by means of a consumer test [29]. Other grains, such as amaranth, quinoa, and buckwheat have been also studied in detail and appreciated as gluten free [30]. Several other cultivated species have been studied occasionally, for example hemp, whose sprouts are destined to become very popular [31]. 
This section, however, is focused on opportunities and research challenges offered by species underexplored for sprouting like voluntary species, wild relatives, ancestors, and neglected/local accessions of cultivated species, and fruit tree species. All of these would be very interesting for sprouting because they are supposed to have a higher phytochemical content compared to cultivated species [32-34].

Research should identify and quantify phytochemicals of these species but also investigate germination performances (\% germination, mean germination time, time to reach a minimum germination threshold) and related methods for improvements. In fact, these species may show dormancy or unpredictable germination, which is a key impediment for sprouting.

\subsection{Voluntary Species, Wild Relatives, Ancestors, Neglected/Local Accessions of Cultivated Species}

None of these species, unlike cultivated species, were subject to breeding programs aimed at increasing yield and fruit size to the detriment of adaptability. They are characterized by high rusticity and tolerance to extreme environmental conditions that can cope with the negative effects of climate change, thereby representing potential contribution to world food security [35]. Their resilience (adaptability) is often due to biochemical mechanisms involving higher contents of secondary metabolites [36]. This also contributes to the high seedling vigor and fast vegetative growth, which warrants competitive adaptability in early growth stages [37]. For these reasons, sprouts from these species are expected to have a very high nutritional value. Some wild species were proposed and studied for micro-scale vegetables production (Table 3) and many other might be considered for sprouting: Galium aparine L. [38], Convolvulus arvensis L. [39], Solanum nigrum L. [40], and Papaver rhoeas L. [41]. An example of sprouts from ancestors of modern species is offered by einkorn, whose sprouts were found to be richer in phenolic substances than those of soft and durum wheat [42].

Table 3. Micro-scale vegetables from voluntary species, wild relatives, and ancient species.

\begin{tabular}{|c|c|c|c|c|}
\hline Family & Species & $\begin{array}{l}\text { Days after Sowing } \\
\text { (DAS) }\end{array}$ & Secondary Metabolites & References \\
\hline \multirow{12}{*}{ Amaranthaceae } & Amaranthus caudatus-amaranth & 10 & PAs, total PC, FC & [43] \\
\hline & Amaranthus cruentus-amaranth & $4,6,7$ & Total PC, AA & {$[44]$} \\
\hline & \multirow{2}{*}{ Amaranthus hypochondriacus-amaranth } & 2 & AA & [45] \\
\hline & & N.S. & Carotenoids & {$[46]$} \\
\hline & \multirow{3}{*}{ Chenopodium album-pigweed } & $48 \mathrm{~h}$ & AA, total PC & [47] \\
\hline & & $48 \mathrm{~h}$ & Total PC & {$[48]$} \\
\hline & & $48 \mathrm{~h}$ & Tocopherols & [49] \\
\hline & \multirow{4}{*}{ Chenopodium quinoa-quinoa } & $4,6,7$ & Total PC, AA & {$[44]$} \\
\hline & & $82 \mathrm{~h}$ & Total PC, AA, single phenolics & {$[50]$} \\
\hline & & 4 & Total PC, AA & [51] \\
\hline & & 5 & Total PC & [52] \\
\hline & Chenopodium berlandieri-huauzontle & $12,24,36,48,72 \mathrm{~h}$ & N.R. & {$[53]$} \\
\hline \multirow{3}{*}{ Apiaceae } & Anethum graveolens-dill & $8-12$ & Total PC, FC, AA & [54] \\
\hline & \multirow{2}{*}{ Coriandrum sativum L.-coriander } & N.S. & Carotenoids, total PC, single phenolics & [55] \\
\hline & & 20 & AA, carotenoids, total PC, single phenolics & [56] \\
\hline \multirow{2}{*}{ Asteraceae } & Artemisia dracunculus-tarragon & $1,3,5,7$ & N/A & [57] \\
\hline & Taraxacum officinale-common dandelion & 16 & Anthocyanins and carotenoids & [58] \\
\hline Boraginaceae & Phacelia tanacetifolia-phacelia & 7 & $\begin{array}{l}\text { Total PC, AA, free and bound } \\
\text { PAs and flavonoids }\end{array}$ & [59] \\
\hline \multirow{3}{*}{ Brassicaceae } & Cichorium intybus-chicory & 12 & $\begin{array}{l}\text { Total PC, tocopherols, anthocyanins, } \\
\text { carotenoids }\end{array}$ & {$[60]$} \\
\hline & \multirow{2}{*}{ Diplotaxis tenuifolia-wild rocket } & 4,7 & Total and single GLS & [61] \\
\hline & & 7,21 & Anthocyanins, phenolics, AA, resveratrol & {$[62]$} \\
\hline Convolvulaceae & Ipomea aquatica-water convolvulus & $8-12$ & Total PC, FC, AA & [54] \\
\hline Malvaceae & Corchorus olitorius L.-jute & 22 & AA, carotenoids, total PC, single phenolics & [56] \\
\hline
\end{tabular}


Table 3. Cont.

\begin{tabular}{|c|c|c|c|c|}
\hline Family & Species & $\begin{array}{l}\text { Days After } \\
\text { Sowing (DAS) }\end{array}$ & Secondary Metabolites & References \\
\hline \multirow{10}{*}{ Poaceae } & Coix lacryma-jobi-adlay seed & $12,24,36,48,60 \mathrm{~h}$ & Free, bound total PC, flavonoid, PAs and AA & [63] \\
\hline & Phalaris canariensis-canary seed & $24,48,72,96,120 \mathrm{~h}$ & Free, bound total PC, PAs and AA & [64] \\
\hline & Triticum aestivum spp. spelta-spelt & 5 and 12 & Total PC, free and bound PAs, AA & [42] \\
\hline & \multirow{3}{*}{$\begin{array}{l}\text { Triticum monococcum ssp. } \\
\text { monococcum-einkorn }\end{array}$} & 5 and 12 & Total PC, free and bound PAs, AA & [42] \\
\hline & & $\begin{array}{l}5 \text { and } 13 \\
5 \text { and } 12\end{array}$ & $\begin{array}{l}\text { Total PC, FC, AA } \\
\text { Total PC, free and bound PAs, AA }\end{array}$ & $\begin{array}{l}{[65]} \\
{[66]}\end{array}$ \\
\hline & & 5 and 9 & Total PC, free and bound PAs, AA & [67] \\
\hline & \multirow{3}{*}{ Triticum turgidum spp. dicoccum-emmer } & 5 and 12 & Total PC, free and bound PAs, AA & [42] \\
\hline & & 5 and 13 & Total PC, FC, AA & {$[45]$} \\
\hline & & 5 and 12 & Total PC, free and bound PAs, AA & [65] \\
\hline & Zizania latifolia-wild rice & & Free, bound and total phenolics & [68] \\
\hline Lamiaceae & Salvia hispanica-chia & 7 & Total PC, AA, free and bound PAs and FC & [59] \\
\hline Leguminosae & Vigna umbellata-rice bean & $6,12,18,24 \mathrm{~h}$ & Total PC, single PAs, single flavonoids and AA & [69] \\
\hline Onagraceae & Oenothera biennis-evening primrose & 7 & $\begin{array}{l}\text { Total PC, AA, free and bound } \\
\text { PAs and flavonoids }\end{array}$ & [59] \\
\hline \multirow{3}{*}{ Portulacaceae } & \multirow[b]{2}{*}{ Portulaca oleracea-common purslane } & $1-6$ & N/A & [70] \\
\hline & & 3 & $\begin{array}{l}\text { Free, bound soluble conjugated total PC, } \\
\text { PAs and flavonoids }\end{array}$ & [71] \\
\hline & Portulaca grandiflora-moss-rose purslane & $1-6$ & N/A & [70] \\
\hline
\end{tabular}

AA = antioxidant activity; FC = flavonoid content; GLS = glucosinolates; N/A = not available; N.R. = not reported;

N.S. = not specified; PAs $=$ phenolic acids; $\mathrm{PC}=$ phenolic content.

Of course, all of these species, especially the wild ones, will be effectively suitable for sprouting only after solving limitations related to low grain yield and seed dispersal at ripening, and seed dormancy [37]. Since many wild species can be considered weeds in agro-ecosystems, these studies might also provide information for weed science and management.

\subsection{Fruit Tree Species}

Seeds of fruit tree species often represent an important by-product of juice/jam food industries, as well as a relevant source of phytochemicals [72]. This is the case of limonoids in Citrus species [73], and of secoiridoids in Olea species [74]. In the last decade, many utilizations were proposed to add value to these agricultural by-products, including the possibility to use them for nutritional purposes [72,75]. The direct consumption of seeds is not possible in many cases, since they are coriaceous, and/or bitter and astringent. Several processing methods have been proposed for extracting phytochemicals from these kinds of seeds, while sprouting is a relatively new option, which would help producing high value food while reducing wastes. To date it has been studied only for grapeseed [76,77], pomegranate [78], olive [79], and Citrus species [80]. In most cases, the increase in phytochemical content and antioxidant activity observed in sprouts in relation to seeds were found to be dramatic (e.g., 30-fold for polyphenols and 90-fold for antioxidant activity in pomegranate), and much higher than in herbaceous species, thus advocating further research. However, among these species, only pomegranate showed acceptable germination rate and time, and a suitable consistency and taste to be actually used for the production of edible sprouts. In the other cases, authors realized that sprouts might better be used for extraction of food additives, cosmetics, and pharmaceuticals.

By analogy with fruit tree species, also fruit-shrub species such as blackberries, raspberries, and blueberries, can be postulated as excellent sources of sprouts, but limitations related to seed dormancy and low germination performances appear hard to overcome. However, considering the large amount of seed wastes obtained from processing, even low germination percentages could be suitable for sprouting purposes. 


\section{Delving into Elicitors}

As previously recalled, phytochemicals have several functions in plants, including protection against abiotic and biotic stressing agents, which may threaten seedling health. Thus, any stressing condition during germination can work as an elicitor, i.e., it may stimulate secondary metabolisms and increase the phytochemical content of sprouts.

Elicitation in sprouts has been recently reviewed by Liu et al. [81]. This section is merely intended at mentioning some underexplored elicitation strategies (Table 4) while prospecting new alternatives.

Among abiotic elicitors, salts applied during sprouting represent a generally available and cheap technique to induce plant defense. Recently, a large body of literature has become available about $\mathrm{NaCl}$ and Se elicitation in sprouting [81,82], but even for these salts there are still questions that need to be addressed. First, the effect of salts may change with the genotype tolerance; thus, evidences in the literature for any species, often obtained with one genotype or a few, should be validated over a greater number of genotypes. Moreover, when studying the effect of an elicitor for sprouting purposes, a much larger variety of doses should be included. In this regard, while a higher level of stress increases the production of phytochemicals, on the other hand it delays and depresses sprout growth. Thus, the elicitor application should be finely tuned to find out the dose that can maximize the "phytochemical yield" as defined by Falcinelli et al. [65], i.e., the product between the sprout biomass and its phytochemical concentration.

Priming of seeds with salts (halo priming) has been little explored with regard to sprouting. Evidence by Hassini et al. [83,84] on cabbage and broccoli seeds primed with $\mathrm{KCl}$ encourage this option. More in general, not only halo priming, but any applicable priming techniques appear to be a compelling area of investigation $[85,86]$.

Se biofortification of sprouts and microgreens represent an intriguing research subject, because it combines the increase of this health promoting micronutrient in sprout tissue with its elicitation effect on secondary metabolites, resulting in an overall improvement of sprout nutritional value. However, this subject is not further discussed here, since it has been thoroughly reviewed in a recent work by D'Amato et al. [82].

Another research subject still unexplored is the effect on the nutritional value of sprouts following the application of elicitation agents to the mother plant. For example, a few studies dealt with the effects of Se in seeds obtained by mother plants subject to Se fertilization [87,88]. In this regard, a challenging matter is represented by possible epigenetic effects that might impact the nutritional value of the corresponding sprouts. Here, a key concept is that different environmental conditions in plants might enhance or suppress the expression of genes associated with phenotypic traits that, eventually, are transferred to the next generations [89]. For example, Marconi et al. [90] found that salinity applied to rapeseed induced genome-wide changes in DNA methylation status, and that these changes accounted for $16.8 \%$ of the total site-specific methylation differences in the rapeseed genome, as detected by methylation-sensitive amplified polymorphism (MSAP) analysis. Preliminary results from a follow-up experiment on the rapeseed sprouts obtained from seeds harvested from salt stressed plants have demonstrated that these sprouts have greater phenolic content and antioxidant activity (Benincasa, unpublished results). It should be pointed out that studies on elicitors would most likely be facilitated by a multidisciplinary approach including investigations on the physiology of seed germination and related genetic implications. These studies, altogether, could lead to breeding protocols towards a higher phytochemical content with beneficial implications on plant adaptation and, more downstream, human health. 
Elicitation should also be investigated in relation to hormesis [91], i.e., the stimulatory effect caused by a toxic compound when applied at very low doses. The beneficial response to hormetins (i.e., the factors inducing hormesis) likely involves an increase of phytochemical content, which has not yet investigated in detail.

Among physical elicitation factors, several have been recently proposed (Table 4). For example, wounding injuries to cotyledons were applied alone or combined with other treatments in soybean sprouts by Aisyah et al. [92]. Ultrasonication has been applied in the sprouting of legumes [93-95], while audible sounds (in the range $20-20,000 \mathrm{~Hz}$ ) were used in the sprouting of mung bean [96].

Nanomaterials (1-100 nm) represent another intriguing subject for sprouting. The effect of nano-silver (NAg) was studied in radish sprouts [97], and that of nano-selenium (NSe) in broccoli sprouts [98]. High levels (600 and $800 \mathrm{ppm}$ ) of $\mathrm{CO}_{2}$, previously shown to induce plant defenses [99], was applied in the sprouting of pea with positive effects on nutritional traits [100]. Magnetic fields were applied to mung bean sprouts by Chen et al. [101] and electromagnetic waves, obtained by simply using a microwave oven, were applied to buckwheat seeds by Wang et al. [102]. Besides their application as elicitors, microwaves, as well as gamma and UV radiation, may also be utilized to reduce seed contamination and related sanitary problems $[93,103]$. The effect of the light spectrum, light intensity, and photoperiod light in the production of micro-scale has been widely studied, as recently reviewed by Alrifai et al. [104]. However, the effect of light spectra on sprouts has been found to be genotype-specific and should be further investigated, considering that the study primarily dealt with red and blue light, whereas the effect of intermediate wavelengths, especially on phytochemical content, has not yet clarified $[105,106]$. Finally, based on the futuristic view of a human presence in the Space, sprouts and microgreens can be considered as ideal candidates for astronauts' diet [107]. To this purpose, Nakajima et al. [108] explored the effect of microgravity by applying clinorotation to the sprouting of mung bean.

When dealing with literature about elicitation in sprouts, a recurrent issue is that data from separate studies are often not comparable, due to differences in the process of sprout development. Moreover, growth stage is often described based on the number of days from the start of incubation, but this does not help in case of genotypes or germination conditions implying different germination times and growth rates. For example, in works on rapeseed and wheat sprouted under salinity, the authors compared treatments in sprouts displaying the same growth stage, therefore sampling after different number of days from the start of incubation, given that treatments with high salinity levels had caused delayed germination and growth [65,66,109].

With regard to biotic factors, fungal inoculation represents a new approach in sprouting. There are several work on this topic [92,110-115], showing evidence about the increase of phytochemical content [112,116]; however, little is known about the metabolic pathways impacted by fungal-plant interactions.

The application of yeasts on sprouts is very intriguing, in light of probiotic benefits that may occur together with the elicitation effects [117-119].

The effect of bacteria inclusion in the substrate or the seeds was studied for buckwheat sprouts and microgreens by Briatia et al. [120], while Eissa et al. [100] reported the effect of Azotobacter chroococcum, Bacillus megaterium, Pseudomonas fluorescens, and their combination on growth performances and nutritional traits of pea sprouts.

Based on the effects shown by fungi and bacteria, one may also wonder whether virus infections play a role in determining the phytochemical content of sprouts. However, to our knowledge, no scientific evidence has ever been shown in this regard. 
Another form of biotic elicitation method concerns the application of biostimulants. These include (1) humic and fulvic acids, (2) animal and vegetal protein hydrolysates, (3) macroalgae seaweeds extracts, (4) silicon, (5) microorganisms (arbuscular mycorrhizal fungi; $\mathrm{N}$-fixing bacteria like Rhizobium, Azotobacter, and Azospirillum) [121]. By definition, biostimulants are mainly employed to enhance plant growth, abiotic stress tolerance and/or quality traits of crops [122], rather than improving the nutritional value of plants for humans. Nonetheless, Witkowicz et al. [123] found that the application of different biostimulants had a significant effect on the nutritional traits of buckwheat sprouts. This influential study, as a result, uncovers new research opportunities, considering the number of key parameters involved (e.g., type, amount, and combination of biostimulants to any plant species) and, within each parameter, the variety of available options.

Elicitation as a consequence of insect attacks is another compelling, and unexplored, area of research. It is well known that plants respond to insects by releasing a wide range of chemical compounds, including volatile entities that convey molecular signals to alert neighboring plants $[18,124]$. Such volatile chemicals cause phenotypic changes and, therefore, carry a potential role as elicitation factors.

It is worth noting that elicitation can be effectively achieved by implementing combinatorial strategies, as shown by Benincasa et al. [87], when high levels of endogenous Se combined with salinity stress were found to synergistically increase the phytochemical content of maize sprouts. However, to date, elicitors have been generally investigated alone and not in combination, thereby precluding observations about possible additive and synergistic effects that could result from versatile and flexible application of variable conditions and parameters (e.g., type, dose, and application method of abiotic and/or biotic factors). 
Table 4. Biotic and abiotic elicitation strategies to raise phytochemical content and corresponding bioactivities in micro-scale vegetables.

\begin{tabular}{|c|c|c|c|c|c|}
\hline Elicitor & Application & Plant & Days after Sowing (DAS) & Phytochemicals/Bioactivities & Reference \\
\hline \multicolumn{6}{|c|}{ Abiotic elicitation-Priming } \\
\hline & Seeds soaked with $30 \mathrm{~mL}$ of $50 \mathrm{mM} \mathrm{KCl}$ & $\begin{array}{l}\text { Brassica oleracea var. } \\
\text { capitata-cabbage }\end{array}$ & 10 & $\downarrow$ total and single GLS & [83] \\
\hline & Seeds soaked with $50 \mathrm{mM} \mathrm{KCl}$ & Brassica oleracea var. italica-broccoli & 10 & $\begin{array}{l}\text { ₹total and single GLS and AA; } \\
\uparrow \text { flavonoids and TP }\end{array}$ & [84] \\
\hline & $\begin{array}{l}\text { 100\% imbibition and aeration of the seeds for } 24 \mathrm{~h} \text {, } \\
\text { with MeJA and JA }(250 \mu \mathrm{M}) \text { and MET }(10 \mathrm{mM})\end{array}$ & $\begin{array}{l}\text { Brassica oleracea var. italica-broccoli } \\
\text { Raphanus sativus-radish }\end{array}$ & 8 & $\begin{array}{l}\begin{array}{l}\text { total GLS with MeJA and JA priming different } \\
\text { effect on single GLS }\end{array} \\
\text {. }\end{array}$ & [85] \\
\hline \multicolumn{6}{|l|}{ Physical factors } \\
\hline Wounding & $\begin{array}{l}\text { Soaked soybeans were wounded prior to germination } \\
\text { stage by cutting the cotyledon individually }\end{array}$ & Glycine max-soybean & 10 & $\uparrow$ glyceollin content (i.e., isoflavones) & [92] \\
\hline \multirow[t]{3}{*}{ Ultrasound } & $\begin{array}{l}\text { Seeds treated with ultrasound at } 360 \text { and } 180 \mathrm{~W} \text { for } 30 \text {, } \\
40 \text {, and } 60 \mathrm{~min} \text { in the ultrasonic bath }\end{array}$ & Phaseolus vulgaris-common bean & $1-4$ & $\uparrow$ PAs, flavonoids, anthocyanins, and AA & [93] \\
\hline & $\begin{array}{l}\text { Seeds treated with ultrasound at } 100,200, \text { and } 300 \mathrm{~W} \\
\text { for } 30 \text { min in the ultrasonic bath }\end{array}$ & Glycine max-soybean & 5 & $\begin{array}{l}\uparrow \text { daidzein and genistein (i.e., isoflavones); } \\
\downarrow \text { daidzein and genistein (i.e., isoflavones) }\end{array}$ & [95] \\
\hline & $\begin{array}{l}\text { Seeds subjected to ultrasound at three frequencies }(28 \text {, } \\
45 \text { and } 100 \mathrm{kHz} \text { ) for } 15,20 \text {, and } 30 \mathrm{~min} \text {. }\end{array}$ & Arachis hypogaea-peanut & $1,2,3,4,5$ & Generally, $\uparrow$ resveratrol content (i.e., stilbenes) & [94] \\
\hline Nanoparticles & $\begin{array}{l}\text { Seeds sprinkled every day with NSePs }(0,10,50 \\
\text { and } 100 \text { ppm); NSePs prepared by chemical reduction } \\
\text { of } \mathrm{NaHSO}_{3} \text { solution with freshly prepared } 0.25 \% \\
\text { glucose solution }(4: 1)\end{array}$ & Brassica oleracea-broccoli & 9 & 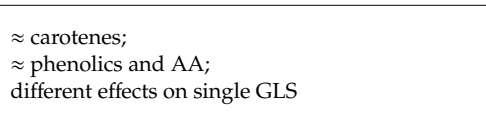 & [98] \\
\hline Magnetic field & $\begin{array}{l}\text { Seeds exposed to } 600 \mathrm{mT} \text { magnetic field pretreatment } \\
\text { (Model: } 2 \mathrm{G} \text { of } 755 \mathrm{R} \text { magnetometer system) }\end{array}$ & Vigna radiata-mung bean & 6 & †anthocyanins & [101] \\
\hline Microwave & $\begin{array}{l}\text { Seeds exposed to microwave irradiation at } 200,400, \\
600 \text {, and } 800 \mathrm{~W} \text { for } 10 \text { or } 30 \mathrm{~s}\end{array}$ & $\begin{array}{l}\text { Fagopyrum esculentum-tartary } \\
\text { buckwheat }\end{array}$ & $3,5,7$ & $\uparrow$ total flavonoids and AA at $600 \mathrm{~W}$ & [102] \\
\hline Clinorotation & $\begin{array}{l}\text { Seeds treated with slow-rotating clinostat (CL) with a } \\
\text { servo motor and an acrylic chamber. An amplifier } \\
\text { controlled the rotation rate, and the chamber was } \\
\text { horizontally rotated at } 2 \mathrm{rpm}\end{array}$ & Vigna radiata-mung bean & $2,3,4$ & $\approx$ carotenoids, except anthocyanins $(\downarrow)$ & [108] \\
\hline \multirow[t]{3}{*}{ Fungi } & $\begin{array}{l}\text { Rhizopus oryzae spore suspension ( } 0.2 \mathrm{~mL} / \mathrm{g} \text { of beans) } \\
\text { added to soybeans during incubation }\end{array}$ & Glycine max-soybean & 10 & $\begin{array}{l}\uparrow \text { total pterocarpans, coumestans (i.e., } \\
\text { isoflavonoids); } \\
\approx \text { isoflavones }\end{array}$ & [92] \\
\hline & $\begin{array}{l}\text { Rhizopus oryzae, Fusarium graminearum CBS } 104.09 \\
\text { and Fusarium oxysporrum CBS 186.53-fungal spore } \\
\text { suspension, applied to 2-day-old seedlings } \\
\text { Spore suspension of Rhizopus oryzae (LU581) }\end{array}$ & $\begin{array}{l}\text { Sinapis alba-yellow mustard; } \\
\text { Brassica napus-rapeseed; } \\
\text { Brassica juncea-Chinese mustard }\end{array}$ & 7 & $\begin{array}{l}\approx \text { total GLS except with Fusarium oxysporum }(\downarrow) \\
\text { in yellow and Chinese mustard }\end{array}$ & [114] \\
\hline & $\begin{array}{l}\text { and Aspergillus oryzzee var. effusus (LU009) }(0.2 \mathrm{~mL} / \mathrm{g} \\
\text { peanuts) added after soaking or after } 2 \text { days of } \\
\text { germination }\end{array}$ & Arachis hypogaea-peanut & 5 or 7 & $\begin{array}{l}\text { Effect on stilbenoids depending on the fungus } \\
\text { and the time of application }\end{array}$ & [110] \\
\hline
\end{tabular}


Table 4. Cont.

\begin{tabular}{|c|c|c|c|c|c|}
\hline Elicitor & Application & Plant & Days after Sowing (DAS) & Phytochemicals/Bioactivities & Reference \\
\hline \multicolumn{6}{|c|}{ Biotic elicitation } \\
\hline & $\begin{array}{l}\text { Rhizopus oryzae (LU 581) and Rhizopus oligosporus } \\
\text { (approximately } 1.5 \times 10^{7} \mathrm{CFU} / \mathrm{g} \text { seed) added to } \\
\text { 2-day-old seedlings }\end{array}$ & $\begin{array}{l}\text { Vigna radiata-mung bean; } \\
\text { Phaseolus vulgaris-common bean; } \\
\text { Glycine max-soybean; } \\
\text { Lupinus albus-white lupine; } \\
\text { Lupinus angustifolius-blue lupine; } \\
\text { Lupinus luteus-yellow lupine; } \\
\text { Arachis hypogaea-peanut; }\end{array}$ & 8 & $\begin{array}{l}\uparrow \text { TP except in mung bean and blue lupin; } \\
\text { different effects on phenolic subclasses (i.e., } \\
\text { flavonoids, phenolic acids, stilbenoids, etc.) }\end{array}$ & [113] \\
\hline & $\begin{array}{l}\text { Spore suspension of Rhizopus oryzae ( } 0.2 \mathrm{~mL} / \mathrm{g} \text { beans) } \\
\text { added to 2-day-old seedlings }\end{array}$ & $\begin{array}{l}\text { Phaseolus vulgaris-common bean; } \\
\text { Phaseolus cocineus-runner bean; } \\
\text { Lablab purpureus-Lablab bean; } \\
\text { Vigna angularis-adzuki bean; } \\
\text { Vigna unguiculata-cowpea; } \\
\text { Vigna radiata-mung bean; } \\
\text { Psophocarpus tetragonolobus-Winged } \\
\text { bean }\end{array}$ & 7 & $\begin{array}{l}\text { †or ₹all isoflavonoids (i.e., coumestans, } \\
\text { isoflavans, pterocarpans, isoflavones, } \\
\text { isoflavanones) }\end{array}$ & [111] \\
\hline & $\begin{array}{l}\text { Spore suspension of Rhizopus oryzae ( } 0.2 \mathrm{~mL} / \mathrm{g} \text { beans) } \\
\text { added to 2-day-old seedlings }\end{array}$ & $\begin{array}{l}\text { Lupinus albus-white lupine; } \\
\text { Lupinus angustifolius-blue lupine; } \\
\text { Lupinus luteus-yellow lupine }\end{array}$ & 7 & $\approx$ or $\uparrow$ genistein derivatives & [112] \\
\hline & $\begin{array}{l}\text { 4-day-old seedlings inoculated by soaking in spore } \\
\text { solution of Rhizopus oryzae for } 50 \mathrm{~min}\end{array}$ & Triticum aestivum-soft wheat & 7 & $\begin{array}{l}\uparrow \text { variety of secondary metabolites mainly } \\
\text { constituted by benzoxazin-3-one glycosides } \\
\text { and benzoxazolinones }\end{array}$ & [115] \\
\hline \multirow[t]{5}{*}{ Yeasts } & $\begin{array}{l}\text { Seeds soaked in distilled water or Lactobacillus } \\
\text { plantarum } 299 \mathrm{v} \text { water suspension }\left(1 \times 10^{8} \mathrm{CFU}\right. \\
\text { per } 1 \mathrm{~g} \text { of seeds }(8.00 \log 10 \mathrm{CFU} / \mathrm{g}) \text { for } 4,6 \text {, and } 8 \mathrm{~h}\end{array}$ & $\begin{array}{l}\text { Lens culinaris-lentil; } \\
\text { Glycine max-soybean; } \\
\text { Vigna angularis-adzuki bean; } \\
\text { Vigna radiata-mung bean }\end{array}$ & 4 & $\approx$ or $\downarrow$ phenolics and condensed tannins & [117] \\
\hline & $\begin{array}{l}\text { Seeds soaked in water or Lactobacillus plantarum } 299 \mathrm{v} \\
\text { water suspension }(8.00 \log 10 \text { CFU/g of seeds) }\end{array}$ & $\begin{array}{l}\text { Lens culinaris-lentil; } \\
\text { Glycine max-soybean; } \\
\text { Vigna angularis-adzuki bean; } \\
\text { Vigna radiata-mung bean }\end{array}$ & 4 & $\begin{array}{l}\approx \text { ability to quench } \mathrm{ABTS}^{\bullet+} \text { and } \\
\text { effects on the ability to different } \\
\text { effects on total and single phenolics } \mathrm{O}_{2} \cdot-\text {;ifferent }\end{array}$ & [119] \\
\hline & $\begin{array}{l}\text { Seeds soaked in distilled water or probiotic } \\
\text { water suspension }\left(1 \times 10^{6} \mathrm{CFU} \text { per } 1 \mathrm{~g} \text { of seeds) of }\right. \\
\text { Saccharomyces cerevoisiae var. boulardii seedlings } \\
\text { sprayed daily with } 5 \mathrm{~mL} \text { of Milli- } \\
\text { water or } 5 \mathrm{~mL} \text { of probiotic water suspension on } 1 \mathrm{st} \\
\text { day of cultivation }\left(1 \times 10^{6} \mathrm{CFU} \text { per } 1 \mathrm{~g} \text { of seeds }\right)\end{array}$ & $\begin{array}{l}\text { Lens culinaris-lentil; } \\
\text { Vigna angularis-adzuki bean }\end{array}$ & 4 & $\approx$ phenolics and antioxidant activities & [118] \\
\hline & $\begin{array}{l}\text { Seeds soaked in distilled water or a Lactobacillus } \\
\text { plantarum } 299 \mathrm{~V} \text { water suspension }\left(1 \times 10^{8} \mathrm{CFU} \text { per } 1\right. \\
\mathrm{g} \text { of seeds) for } 4 \mathrm{~h}\end{array}$ & Glycine max-soybean & 4 & $\begin{array}{l}\downarrow \text { total isoflavones in fresh sprouts; } \\
\text { different effects on single isoflavones; } \\
\uparrow \text { antioxidant activity }\end{array}$ & [125] \\
\hline & $\begin{array}{l}\text { Sprouts treated with } 50,100,200,400 \text { and } 800 \mathrm{mg} / \mathrm{L} \text { of } \\
\text { YPS (polysaccharide fraction of YE, Y4250) on days } 0 \text {, } \\
3,6, \text { and } 9\end{array}$ & $\begin{array}{l}\text { Fagopyrum esculentum-tartary } \\
\text { buckwheat }\end{array}$ & $0,3,6,9$ & $\uparrow$ flavonoids in 3-,6-, and 9-day -old sprouts & [126] \\
\hline
\end{tabular}


Table 4. Cont.

\begin{tabular}{|c|c|c|c|c|c|}
\hline Elicitor & Application & Plant & Days after Sowing (DAS) & Phytochemicals/Bioactivities & Reference \\
\hline \multicolumn{6}{|l|}{ Biotic elicitation } \\
\hline \multirow[t]{3}{*}{ Bacteria } & $\begin{array}{l}\text { Seeds were surface-sterilized with sodium } \\
\text { hypochlorite and rinsed with distilled water. Then, } \\
\text { seeds were soaked in liquid suspension of endophytic } \\
\text { bacterium, (ST-B2 strain, isolated from stem of } \\
\text { buckwheat) at } 0,10 \% \text { and } 20 \% \text { concentrations for } 4 \mathrm{~h} \\
\text { at room temperature }\end{array}$ & Fagopyrum esculentum-buckwheat & 10 & Not analyzed & [120] \\
\hline & $\begin{array}{l}\text { Bacillus megaterium } 10^{8} \mathrm{CFU} / \mathrm{mL} \text { added } 10 \text { days before } \\
\text { the cultivation of seeds, while } A z \text { zotobacter chroococcum } \\
\text { and Pseudomonas fluorescens } 10^{8}-10^{9} \mathrm{CFU} / \mathrm{mL} \text { were } \\
\text { added after pea sprouts emergence and after the 1st } \\
\text { cut. Eight sub-treatments from different combinations } \\
\text { of microbial inoculants were carried out }\end{array}$ & Pisum sativum-pea & 14 (1st cut) and 12 (2nd cut) & Not analyzed & [100] \\
\hline & $\begin{array}{l}\text { Seeds soaked for } 30 \mathrm{~min} \text { in 1:40 solutions of PGPs } \\
\text { named Serenade ASO, containing Bacillus subtilis QST } \\
713 \text { at a concentration of } 13.96 \mathrm{~g} / \mathrm{L}(1.34 \%)\end{array}$ & Fagopyrum esculentum-buckwheat & 14 & Not analyzed & [123] \\
\hline Algae & $\begin{array}{l}\text { Seeds soaked for } 30 \text { min in PGPs: } 1: 100 \text { solution of } \\
\text { Kelpak SL (Ecklonia maxima extract), and } 2 \mathrm{~g} \text { in } 500 \mathrm{~mL} \\
\text { of Polyversum WP (106 Pythium oligandrum oospores } \\
\text { per 1 g) }\end{array}$ & Fagopyrum esculentum-buckwheat & 14 & Not analyzed & [123] \\
\hline Other biostimulants & $\begin{array}{l}\text { Seeds soaked for } 30 \mathrm{~min} \text { in } 1: 500 \text { solution of PGPs } \\
\text { named Asahi SL (mixture of } \\
\text { sodium p-nitrophenolate, sodium o-nitrophenolate, } \\
\text { sodium } \\
\text { 5-nitroguaiacolate) }\end{array}$ & Fagopyrum esculentum-buckwheat & 14 & Not analyzed & [123] \\
\hline
\end{tabular}

$\mathrm{AA}=$ antioxidant activity; $\mathrm{CBS}=$ CentraalBureau voor Schimmelcultures (Fungal Biodiversity Centre); $\mathrm{CFU}=$ colony-forming unit; GLS = glucosinolates; JA = jasmonic acid; MeJA = ethyl jasmonate; MET = DL-methionine; PAs = phenolic acids; PGPs = plant growth promoters; $\mathrm{TP}=$ total phenolics; $\mathrm{YE}=$ yeast extract; $\mathrm{YPS}=\mathrm{Yu}$-Ping-Feng polysaccharides. 


\section{Sanitization and Processing}

Sprouts and microgreens are mainly used for homemade preparations and fresh food markets. Suitable handling practices, techniques for domestic and industrial food storage, and safety procedures are therefore required to ensure shelf life and food quality, and prevent microbiological contaminations that could pose risks to human health. In this regard, research must consider as well optimized germination protocols while preserving the nutritional value of sprouts and microgreens. This may include, for example, breeding programs aimed at genetic improvement and valorization of autochthonous cultivars and/or wild species to select genotypes associated with improved post-harvest storage.

Sprouts and microgreens are subject to different processing avenues, such as freezing, drying, waving, microwaving, frying, toasting, boiling, or centrifugation (for sprout juice production), to arrive at final applications where, ideally, phytochemical content, and overall nutritional value are fully retained. This is particularly important when sprouts represent the source of supplements to improve food quality, as in sprouted bread [127], other bakery products, and juices.

Research in this field would therefore benefit most from interdisciplinary collaborations between geneticists, microbiologists, and food technologists.

\subsection{Microbiological Safety of Sprouts and Microgreens}

When, in several instances, food-borne illness outbreaks have been linked to sprouts' consumption, at the same time no reported outbreaks or illnesses were associated to microgreens. This is not very surprising if we consider that, from a microecological standpoint, production of sprouts, and microgreens differ in a number of operating steps: microgreens undergo a brief seed-soaking period, are generally grown on substrate, and are consumed, after cutting, without the root system. On the other hand, sprouts are eaten raw together with their roots. Thus, many food agencies classify sprouts as "high-risk" products, while microgreens are considered much safer, although some (low) risks can arise from fresh herbs (basil, thyme) or baby-leaf vegetables (baby spinach) [128-131].

The most common agents causing outbreaks in relation to sprouts consumption include Salmonella, Escherichia coli O157:H7, and Shiga-toxin-producing E. coli [128,129,131,132]. Instead, other bacterial pathogens (e.g., Bacillus cereus, Staphylococcus aureus, Listeria monocytogenes, and Yersinia enterocolitica) have rarely been reported $[131,133]$. Indeed, Salmonella and E. coli O157:H7, unlike Listeria monocytogenes, can internalize into seedlings, thus, making ineffective simple washing treatments or topical disinfectants $[129,134]$. Consequently, pre-harvest interventions could effectively enhance the microbiological safety of sprouts [129], even in the absence of a validated Critical Control Point (CCP) intended to at least reduce levels of the fecal pathogen to acceptable standards $[131,133,135]$.

Typically, contaminations occur first in the seeds, and then spread to sprouts. Microbiological threats can be minimized through Good Agricultural Practices (GAP) as well as Good Handling Practices (GHP) along seed production stages [136]. In particular, soil amendments (i.e., compost or manure) and irrigation water require adequate controls, especially for species not usually employed in the whole sprouts/microgreens production chain (e.g., alfalfa and clover seeds not specifically produced for sprouts cultivation) and, more particularly, those newly introduced or potentially considered for consumers and the fresh market. For example, Liu et al. [137] recently showed that S. enterica and E. coli O157:H7 strains artificially inoculated into alfalfa, fenugreek, lettuce, and tomato flowers, had subsequently moved into the seeds (produced by contaminated flowers), and then to sprouts and seedlings, thus, showing the ability of Salmonella to survive and spread.

Efforts regarding sprout safety have mainly been focused on pathogen detection, as well as seed testing (including seed traceability) and disinfection. In this regard, a large body of literature has been produced to show effective seed disinfection procedures and, at the same time, specific steps aimed at ensuring high germination percentage and rate together with optimal yields and quality of sprouts. Disinfection methods fall into three main categories, i.e., chemical, physical, and biological, which have extensively been reviewed by Ding et al. [128], and by Warriner and Smal [129]. 
The application of 20,000-ppm calcium hypochlorite is likely the most commonly used chemical treatment. However, although recommended by the Food and Drug Administration (FDA), this method carries distinct drawbacks concerning worker safety and environmental impact, difficulty to make organic food claims, disinfection efficacy that may vary in relation to the physical properties of the seed surface (e.g., smooth vs scarified) [128,130], and impact on product quality [138]. Consequently, there is a need for alternative methods that optimally combine disinfection efficacy with safety and environment-friendly features. Table 5 summarizes the studies that have been performed in this field over the last 5 years (2016 onward) for applications in sprouts production. Notably, it should be clarified that, to date, seed disinfection is primarily based on physical methods, and that combination of physical, chemical, and biological treatments have also been shown to be particularly valuable in light of observed synergistic effects [128].

However, microbial control studies have generally been centered on seeds of a relatively small number of species, thereby leaving ample room for additional research on those of less common varieties. In this context, another research gap to fill is about the development of methods that can routinely be performed in household preparations, when seed disinfection is often neglected [139].

GAP should be applied during sprouting (e.g., germination and irrigation water tests [140]) whereas GHP should be implemented during harvest and post-harvest procedures [141]. Moreover, post-harvest microbiological control by washing treatments could damage vegetable tissues, thereby decreasing sprouts' shelf life. Physical disinfection methods, including irradiation, have proven to be effective post-harvest practices in the preparation of microbiologically safe sprouts [129]. Gamma irradiation (1-2.5 kGy) in combination with ultrasonication (4-10 $\left.\mathrm{min} ; 40-50^{\circ} \mathrm{C}\right)$, blanching $\left(50-70{ }^{\circ} \mathrm{C}\right.$ for $4-10 \mathrm{~min}$ using potable water) and ascorbate dip $\left(0.25 \%, 5 \%\right.$ and $1 \%$ up to $10 \mathrm{~min}$ at $\left.4 \pm 1{ }^{\circ} \mathrm{C}\right)$ ensured microbial safety in mung bean, chickpea, and alfalfa sprouts together with an extended shelf life of the final products [103].

Similar concepts, rationales, and methods apply to microgreen productions although an additional $\mathrm{CCP}$, as for raw products in general, should be indicated (see also Turner et al. [142]). Indeed, harvesting by cutting may increase susceptibility to contamination, since the cut site may be a breach from where pathogens can enter the system [130], as already reported in lettuce [143]. Screening for pathogens in sprouting seedbeds should also be performed [129], since soil and soil substitutes could provide a direct nutrient source as well as a protective surface from mechanical damage, thus promoting their proliferation or survival [144-146]. In this regard, Iş1k et al. [144] have studied the possible transfer of non-pathogenic and pathogenic E. coli from contaminated growth media to the edible part of radish and lettuce microgreens. Moreover, hydroponic systems, which are preferably chosen by modern commercial facilities, are not safer than other growing systems [142]. Unlike sprouts, microgreens sanitization processes before and after harvest require additional research, particularly to address the correlation between morphological characteristics and efficacy of sanitizers.

Lastly, in terms of pathogen detection, efforts are necessary to develop rapid and cost-effective screening tests that, ideally, are applicable to homemade productions (e.g., biosensors capable of detecting toxic molecules or pathogens in fresh products).

\subsection{Post-Harvest Shelf Life and Processing}

Sprouts and microgreens consist of young tissues characterized by higher respiration rates than their mature counterparts, leading to a more rapid post-harvest deterioration of quality, even at relatively low temperatures. Several practices can contribute to the extension of sprouts and microgreens shelf life, including pre-harvest and pre-storage calcium applications $[147,148]$ to pre-packaging washing and dewatering processes [2]. Microgreens could also be commercialized directly in containers and harvested by the end user, bypassing post-harvest handling, and ensuring greater freshness quality $[2,6]$. Genotype, growing period, cultivation systems and time for harvesting could affect post-harvest quality of microgreens, since these factors significantly influence the accumulation of non-enzymatic antioxidant compounds (i.e., carotenoids, phenols and ascorbic acid), as already reported 
for other ready-to-eat vegetables [149]. In sprouts, however, knowledge about polyphenol oxidases (PPOs) remain elusive except for some data concerning PPO inhibition mechanisms. In this regard, Sikora et al. [150] found two PPO isoenzymes in lentil sprouts, and over $40 \%$ total PPO activity inhibited by $2 \mathrm{mM}$ ascorbic acid. Notably, ascorbic acid resulted effective also in terms of overall acceptability characteristics (i.e., color and appearance, taste, aroma, texture) in 7-day old sunflower microgreens [151].

In any case, temperature (firstly), atmospheric composition, packaging technologies, initial microbial load, and light exposure during post-harvest are among the most critical factors underlying shelf life.

A $0{ }^{\circ} \mathrm{C}$ temperature can be considered the optimal storage temperature for most of leafy and fresh-cut vegetables, in that it causes a reduction of both plant and microorganisms' metabolic activities [7]. However, information on specie-specific chilling sensitivity and respiration rates, together with the effects of cold storage on nutrient digestibility, bio accessibility of pro-health constituents and organoleptic quality of sprouts and microgreens, await further investigations in order to improve post-harvest methodologies. In 4-day-old soybean sprouts, the contents of isoflavones after a 7-day cold storage $\left(4^{\circ} \mathrm{C}\right)$ were generally equal or higher than in fresh sprouts [125], while $4{ }^{\circ} \mathrm{C}$ storage for more than 7 days revealed a significant decrease of glucosinolates in Brassica oleracea sprouts [152]. Plant species seem to play a pivotal role also in terms of dynamics of sprouts' microbiome during cold storage [153], but further investigations are still needed. Recently, high hydrostatic pressure (HHP) was effectively tested under cold storage $\left(4^{\circ} \mathrm{C}\right)$ on mung bean sprouts, showing positive effects on amino acid concentrations [154]. Moreover, Westphal et al. [155] have demonstrated that high-pressure processing (HPP) had no negative effects on the glucosinolate-myrosinase system in broccoli sprouts.

Packaging proved to be significant for the shelf life of sprouts and microgreens [156]. In general, higher products' post-harvest performance is supported by a relatively high $\mathrm{O}_{2}$ atmosphere equilibrated under modified atmosphere packaging (MAP) with high oxygen transmission rate films [2,157]. To this purpose, Wilson et al. [158] reviewed innovative MAP technologies in fresh and freshly-cut vegetables including differentially permeable films with antimicrobial properties, elevated levels of non-traditional gases (i.e., argon, xenon), and smart packaging coupled to sensor technologies. Further efforts should be made to test all these packaging possibilities in sprouts and microgreens production chains. Studies should also address the effects of light exposure during storage on post-harvest decay and product's quality, considering that, especially for microgreens, available data appear somewhat inconclusive [142].

Beside fresh consumption, sprouts and microgreens are suitable for creating novel food products, such as juices [159], fermented drinks (i.e., juices [160]), or foods such as breakfast or snack foods, seasonings (e.g., vinegar or sauce), and weaning foods [161], probiotic beverage or foods [162], yogurt [163], powder enriched flours [164,165], and bakery products [127,166-168], and, more recently, tea [169], as well as food matrices [170]. Furthermore, the use in flour mixture of powder from sprouted wheat pomace, as by-product from juice production, was recently evaluated and found to increase of nutritional value in relation to wheat flour [171]. Processing treatments play a determinant role in maintaining biochemical quality of raw material, depending on the specific kind of processing as well as its application conditions, plant genotype, ontogenetic stage, overall plant composition, and chemical structure of specific metabolites. Conditions and methods of sprouts drying should be chosen based on whether quality can be preserved or enhanced. For example, in broccoli sprouts the highest efficiency of grinding as well as the higher total phenolic content and antioxidant activity were obtained from freeze-dried (frozen and lyophilized at $40{ }^{\circ} \mathrm{C} ; 52 \mathrm{~Pa}$ ) materials, although air-dried at $40^{\circ} \mathrm{C}$ (air flowing, $0.5 \mathrm{~ms}^{-1}$ ) could be also recommended [172]. In alfalfa and flax sprouts, freeze-drying minimized the chemical alteration of the product, resulting in a better preservation of antioxidants and an increase in phytosterol availability [173]. Conversely, air drying at 70 and $80^{\circ} \mathrm{C}$ for $24 \mathrm{~h}$, as opposed to freeze drying (below $-50{ }^{\circ} \mathrm{C}$ and $0.3 \mathrm{mbar}$ vacuum pressure, $36 \mathrm{~h}$ ), increased total phenolic content and antioxidant capacity of mung bean sprouts [174]. Pan-roasting of cereal (barley, wheat) sprouts was 
shown a promising heat processing for tea production, based on higher total phenolics and flavonoid contents and antioxidative effects in-vitro compared to a steaming process [169]. With respect to plant varieties, the phenolic content measured in 4-days-old sprouts of Chenopodium quinoa appear to be thermostable in the range $30-60^{\circ} \mathrm{C}$ in the white variety (from Chile), whereas it significantly decreased after drying at $60^{\circ} \mathrm{C}$ in the red variety (from Bolivia) [175]. The impact of bread-making on secondary plant metabolites was evaluated in dough enriched with 7-days-old pak choi and kale microgreens [165]. Authors confirmed the effects of thermal processing in reducing the concentrations of secondary plant metabolites; however, after bread-making it was observed the formation of structurally different secondary plant metabolites (e.g., pheophytin) and the increase in hydroxycinnamic acid derivatives (in kale), which may also confer health-promoting effects. In the case of legume-enriched breads, the bread-making process led to a slight reduction in kaempferol glycosides and chrysoeriol glycosides in bread supplemented with pea and lupin microgreens, respectively [176].

For juice production, thermal processing continues to be the principal pasteurization method given its historical use, cost, and predictability [177]. However, recent nonthermal pasteurization methods such as HPP and ultraviolet-C (UV-C) have been applied for juice pasteurization $[178,179]$. For wheatgrass juice, Ali et al. [180] indicated HHP as the preferred alternative pasteurization process due to its negligible impact on antioxidants and the increase in chlorophyll content. 
Table 5. Overview of recent studies (dated 2016 onward) about disinfection methods applied to seeds employed for sprout production.

\begin{tabular}{|c|c|c|c|c|c|c|c|}
\hline Disinfection Method & Disinfection Conditions & Plant Species & Pathogen/s & Treatment Effectiveness & $\begin{array}{l}\text { Effects on Seed } \\
\text { Germination }\end{array}$ & Effects on Sprouts Yield/Quality & References \\
\hline \multicolumn{8}{|l|}{ Chemical } \\
\hline Bleach & $1 \mathrm{~mL} \mathrm{NaClO}(4 \% v / v), 15 \mathrm{~min}$ & Fenugreek & $\begin{array}{l}\text { Shiga toxin-producing } \\
\text { Escherichia coli OO104:H4 }\end{array}$ & $\begin{array}{l}\text { On seeds: no detectable } \\
\text { colonies }\end{array}$ & Not affected & Not affected & [181] \\
\hline $\begin{array}{l}\text { Acidified (organic acids) } \\
\text { essential oil nanoemulsions }\end{array}$ & $\begin{array}{l}50 \mathrm{mM} \text { acetic acid } \\
50 \mathrm{mM} \mathrm{levulinic} \mathrm{acid} \mathrm{carvacrol} \mathrm{nanoemulsion,} \\
4000 / 8000 \mathrm{ppm}, 30 \mathrm{~min}\end{array}$ & $\begin{array}{l}\text { Mung bean, } \\
\text { broccoli }\end{array}$ & $\begin{array}{l}\text { Salmonella enterica } \\
\text { Enteritidis cocktail }\end{array}$ & $\begin{array}{l}\text { On seeds: } 2-4 \log \mathrm{CFU} / \mathrm{g} \\
\text { reduction-specie dependent; } \\
\text { on sprouts: no detectable } \\
\text { pathogens (<1.5 log CFU/g) }\end{array}$ & Not affected & Not affected & [182] \\
\hline Chlorinated water & $\begin{array}{l}\text { Treatment 1: seeds soaking, } 100 \mathrm{ppm}, 60 \mathrm{~min} \text {; } \\
\text { treatment 2: sprouts washing, } 4 \text { times } / 5 \mathrm{~min} \\
\text { each, } 100 \mathrm{ppm}\end{array}$ & Mung bean & $\begin{array}{l}\text { Shiga toxin-producing } \\
\text { Escherichia coli } \\
\text { Salmonella spp. } \\
\text { Listeria monocytogenes }\end{array}$ & $\begin{array}{l}\text { On seeds: } 3.0 \log \mathrm{CFU} / \mathrm{g} \\
\text { reduction; } \\
\text { on sprouts: } 7.0 \log \mathrm{CFU} / \mathrm{g} \\
\text { reduction }\end{array}$ & - & - & [183] \\
\hline Chlorine dioxide $\left(\mathrm{ClO}_{2}\right)$ & $3 \mathrm{ppm} \mathrm{ClO}_{2}, 10 \mathrm{~min}$ & Alfalfa & Listeria monocytogenes & $\begin{array}{l}\text { On seeds: not effective; } \\
\text { on sprouts: not effective }\end{array}$ & - & - & [184] \\
\hline Chlorophyllin (Chl) & $\begin{array}{l}1.5 \times 10^{-5} \mathrm{M} \mathrm{Chl} \text {, incubation time } 1 \mathrm{~h}, 405 \mathrm{~nm}, \\
\text { radiant exposure: } 18 \mathrm{~J} \mathrm{~cm}^{-2}, 1 \mathrm{~h}\end{array}$ & Wheat & Escherichia coli & On seeds: $\sim 1.5 \log \mathrm{CFU} / \mathrm{g}$. & - & - & [185] \\
\hline $\begin{array}{l}\text { Peracetic acid (PAA)-based } \\
\text { solution }\end{array}$ & $\begin{array}{l}\text { PAA solution }(5 \% v / v) \text { diluted in EtOH }(20 \% \\
v / v) 1: 9\end{array}$ & $\begin{array}{l}\text { Flax, } \\
\text { chia }\end{array}$ & $\begin{array}{l}\text { Salmonella spp. } \\
\text { Enterococcus faecium }\end{array}$ & $\begin{array}{l}\text { On seeds: } 4.0-5.0 \log \text { CFU } / g \\
\text { reduction-specie dependent }\end{array}$ & Not affected & - & [186] \\
\hline Saline organic acid solutions & $\begin{array}{l}\text { Tempering solutions: lactic acid }(5 \% \mathrm{v} / v) \\
\text { and } \mathrm{NaCl}(\sim 26 \% \mathrm{w} / \mathrm{v})\end{array}$ & $\begin{array}{l}\text { Soft wheat, } \\
\text { durum wheat }\end{array}$ & $\begin{array}{l}\text { Salmonella enterica } \\
\text { Escherichia coli O157:H7 } \\
\text { Shiga toxin-producing } \\
\text { Escherichia coli }\end{array}$ & $\begin{array}{l}\text { On seeds: } 1.6-2.6 \log \mathrm{CFU} / \mathrm{g}- \\
\text { specie and pathogen dependent }\end{array}$ & - & - & [187] \\
\hline $\begin{array}{l}\text { Slightly acidic/acidic } \\
\text { electrolyzed water } \\
\text { (SAEW/AEW) }\end{array}$ & $\begin{array}{l}\text { Available chorine concentrations (ACC) } \\
150 \mathrm{mg} / \mathrm{L}, 24 \mathrm{~h}, 1.5 v / 0\end{array}$ & Brown rice & Bacillus cereus & $\begin{array}{l}\text { On sprouts: } 2.3 \log \mathrm{CFU} / \mathrm{g} \\
\text { reduction }\end{array}$ & $\uparrow \downarrow \mathrm{pH}$ dependent & $\uparrow \downarrow$ growth $-\mathrm{pH}$ dependent & [188] \\
\hline SAEW & $\begin{array}{l}\text { ACC 10.3-91.7 mg/L } \\
\text { sprouts washing }(1: 3 w / v), 5 \mathrm{~min}\end{array}$ & Buckwheat & $\begin{array}{l}\text { Escherichia coli } \mathrm{O} 78 \\
\text { Listeria monocytogenes }\end{array}$ & $\begin{array}{l}1.1-2.7 \log \mathrm{CFU} / \mathrm{g} \\
\text { reduction-pathogen dependent }\end{array}$ & Not affected & $\downarrow$ sprout length-ACC dependent & [189] \\
\hline SAEW & $\begin{array}{l}\text { ACC } 70.0 \mathrm{mg} / \mathrm{L} \\
\text { seeds washing }(1: 5 \mathrm{w} / \mathrm{v}), 3 \text { times }\end{array}$ & Pea & $\begin{array}{l}\text { Natural population of total } \\
\text { bacteria }\end{array}$ & $\sim 2.0 \log \mathrm{CFU} / \mathrm{g}$ reduction. & - & $\begin{array}{l}\text { Yield not affected; } \\
\uparrow \text { soluble sugars; } \\
\downarrow \text { nitrite }\end{array}$ & [190] \\
\hline SAEW & $\begin{array}{l}\text { ACC } 25.0-45.0 \mathrm{mg} / \mathrm{L} \\
\text { seeds soaking }(1: 5 w / v), 0.5 \mathrm{~h}\end{array}$ & Alfalfa & Natural Enterobacteriaceae & $\begin{array}{l}\text { On seeds: } 2.5 \log \mathrm{CFU} / \mathrm{g} \\
\text { reduction; } \\
\text { on sprouts: } 0.7-1.8 \log \mathrm{CFU} / \mathrm{g} \\
\text { reduction }\end{array}$ & $\begin{array}{l}\uparrow \text { or not affected - } \\
\text { pH dependent }\end{array}$ & Not affected & [191] \\
\hline Zinc diacetate & $\begin{array}{l}\text { Concentration } 400 \mathrm{mg} / \mathrm{L} \\
\text { seeds soaking } 0.66 \mathrm{~h}, 18^{\circ} \mathrm{C}\end{array}$ & Durum wheat & Natural bacteria population & $\begin{array}{l}\text { On sprouts: } 2.0 \log \mathrm{CFU} / \mathrm{g} \\
\text { reduction }\end{array}$ & Slightly decreased & $\begin{array}{l}\uparrow \text { ash, lipids, proteins, zinc, vitamin } \\
\text { C, total phenol content }\end{array}$ & [192] \\
\hline \multicolumn{8}{|l|}{ Physical } \\
\hline $\begin{array}{l}\text { Atmospheric pressure plasma } \\
\text { discharge }\end{array}$ & $\begin{array}{l}\text { Atmospheric } \\
\text { pressure volumetric dielectric barrier } \\
\text { discharge (DBD), } 10 \mathrm{kHz}, 8 \mathrm{KV}, 500 \mathrm{~ns} \text { pulses, } \\
5 / 10 \mathrm{~min}\end{array}$ & $\begin{array}{l}\text { Alfalfa, } \\
\text { onion, } \\
\text { radish, } \\
\text { cress }\end{array}$ & Escherichia coli & $\begin{array}{l}\text { On seeds: } 1.4-3.4 \log \mathrm{CFU} / \mathrm{g} \\
\text { reduction-specie dependent }\end{array}$ & $\begin{array}{l}\uparrow \downarrow \text { depending on } \\
\text { temperature, time, } \\
\text { pulse frequency or } \\
\text { voltage }\end{array}$ & - & [193] \\
\hline
\end{tabular}


Table 5. Cont.

\begin{tabular}{|c|c|c|c|c|c|c|c|}
\hline Disinfection Method & Disinfection Conditions & Plant Species & Pathogen/s & Treatment Effectiveness & $\begin{array}{l}\text { Effects on Seed } \\
\text { Germination }\end{array}$ & Effects on Sprouts Yield/Quality & References \\
\hline Gamma ray irradiation & $7 \mathrm{kGy}, 0.073 \mathrm{kGy} / \mathrm{min}, 4-5^{\circ} \mathrm{C}$ & $\begin{array}{l}\text { Mung bean, clover, } \\
\text { fenugreek }\end{array}$ & Escherichia coli & $\begin{array}{l}\text { On seeds: } 5.0 \log \mathrm{CFU} / \mathrm{g} \\
\text { reduction-specie dependent }\end{array}$ & $\begin{array}{l}\downarrow \downarrow \text { species } \\
\text { dependent }\end{array}$ & $\downarrow$ yield & [194] \\
\hline Electron-beam irradiation & $\begin{array}{l}12 \mathrm{kGy}, 140 \mathrm{kV}, 87 \mathrm{~mm} / \mathrm{s}(12 \mathrm{kGy}) \text { and } 250 \\
\mathrm{~mm} / \mathrm{s}(4 \mathrm{kGy})\end{array}$ & $\begin{array}{l}\text { Mung bean, clover, } \\
\text { fenugreek }\end{array}$ & Escherichia coli & $\begin{array}{l}\text { On seeds: not completely } \\
\text { inactivated-specie dependent }\end{array}$ & Not affected & Not affected & [193] \\
\hline Chlorine + drying + dry heat & $\begin{array}{l}\mathrm{ClO}_{2}-200 \mathrm{mg} / \mathrm{mL}, 5 \mathrm{~min} ; \\
45^{\circ} \mathrm{C}, 23 \% \mathrm{RH}, 24 \mathrm{~h} ; \\
80^{\circ} \mathrm{C}, 23 \% \mathrm{RH}, 43 \mathrm{~h}\end{array}$ & Pack choi & $\begin{array}{l}\text { Salmonella enterica } \\
\text { Escherichia coli } \mathrm{O} 157: \mathrm{H} 7\end{array}$ & $\begin{array}{l}\text { On seeds: }>3.8 \log \mathrm{CFU} / \mathrm{g} \\
\text { reduction-pathogen dependent }\end{array}$ & Not affected & - & [195] \\
\hline $\begin{array}{l}\text { Cold atmospheric pressure } \\
\text { plasma }\end{array}$ & $400 \mathrm{~W}, 5 \mathrm{~min}$ & Lentil & $\begin{array}{l}\text { Escherichia coli } \\
\text { Salmonella spp. } \\
\text { Listeria monocytogenes }\end{array}$ & $\begin{array}{l}\text { On seeds: } 5.0 \log \mathrm{CFU} / \mathrm{g} \\
\text { reduction-pathogen dependent }\end{array}$ & $\downarrow$ after $180 \mathrm{~s}$ & - & [196] \\
\hline High-intensity light pulses & $19.35 \mathrm{~J} / \mathrm{cm}^{2}, 15 \mathrm{~s}$ & Chia & Salmonella Typhimurium & $\begin{array}{l}\text { On seeds: } 4.0 \log \mathrm{CFU} / \mathrm{g} \\
\text { reduction. }\end{array}$ & - & - & [197] \\
\hline Intense pulsed light & $\begin{array}{l}24.50 \text { and } 20.81 \mathrm{~J} / \mathrm{cm}^{2} \text { - depending on plant } \\
\text { species }\end{array}$ & $\begin{array}{l}\text { Radish, } \\
\text { pak choi }\end{array}$ & $\begin{array}{l}\text { Natural total aerobic } \\
\text { mesophilic bacteria }\end{array}$ & $\begin{array}{l}\text { On seeds: } 1.4-1.8 \log \mathrm{CFU} / \mathrm{g} \\
\text { reduction-specie dependent }\end{array}$ & $\begin{array}{l}\text { Not affected or } \\
\text { slightly decreased }\end{array}$ & Sprout length not affected & [198] \\
\hline Nonthermal plasma & Corona discharge plasma jet, $3 \mathrm{~min}$ & Radish & $\begin{array}{l}\text { Aerobic bacteria } \\
\text { Bacillus cereus } \\
\text { Escherichia coli } \\
\text { Salmonella spp. }\end{array}$ & $\begin{array}{l}\text { On seeds: } 1.2-2.1 \log \mathrm{CFU} / \mathrm{g} \\
\text { reduction-pathogen } \\
\text { dependent;on sprouts: }>2.0 \log \\
\text { CFU/g reduction-pathogen } \\
\text { dependent }\end{array}$ & $\begin{array}{l}\uparrow \downarrow \text { treatment time } \\
\text { dependent }\end{array}$ & $\begin{array}{l}\downarrow \uparrow \text { yield-treatment time } \\
\text { (min)dependent; } \\
\downarrow \text { slightly brightness and redness; } \\
\text { not affected reducing sugars, total } \\
\text { phenolics, radical } \\
\text { scavenging activity }\end{array}$ & [199] \\
\hline Nonthermal plasma & Corona discharge plasma jet, $3 \mathrm{~min}$ & Rapeseed & $\begin{array}{l}\text { Aerobic bacteria } \\
\text { Bacillus cereus } \\
\text { Escherichia coli } \\
\text { Salmonella spp. }\end{array}$ & $\begin{array}{l}\text { On seeds: } 1.2-2.2 \log \mathrm{CFU} / \mathrm{g} \\
\text { reduction-pathogen dependent; } \\
\text { on sprouts: } \sim 2.0 \log \mathrm{CFU} / \mathrm{g} \\
\text { reduction-pathogen dependent }\end{array}$ & $\begin{array}{l}\uparrow \downarrow \text { treatment time } \\
\text { dependent }\end{array}$ & $\begin{array}{l}\downarrow \uparrow \text { yield - treatment time dependent; } \\
\text { not affected reducing sugars, total } \\
\text { phenolics, radical } \\
\text { scavenging activity; } \\
\downarrow \text { slightly "appearance", "flavor", } \\
\text { "taste", "overall } \\
\text { acceptance"-treatment time } \\
\text { dependent }\end{array}$ & [200] \\
\hline Nonthermal plasma & Corona discharge plasma jet, $3 \mathrm{~min}$ & Broccoli & $\begin{array}{l}\text { Aerobic bacteria } \\
\text { Bacillus cereus } \\
\text { Escherichia coli } \\
\text { Salmonella spp. }\end{array}$ & $\begin{array}{l}\text { On seeds: } 1.2-2.3 \log \mathrm{CFU} / \mathrm{g} \\
\text { reduction-pathogen dependent; } \\
\text { on sprouts: } \sim 2.0 \log \mathrm{CFU} / \mathrm{g} \\
\text { reduction-pathogen dependent }\end{array}$ & $\begin{array}{l}\uparrow \downarrow \text { treatment time } \\
\text { dependent }\end{array}$ & $\begin{array}{l}\downarrow \uparrow \text { yield - treatment time dependent; } \\
\text { not affected reducing sugars, total } \\
\text { phenolics, radical } \\
\text { scavenging activity; } \\
\uparrow \text { slightly "flavor"; } \\
\downarrow \text { lsightlly appearance", "color", } \\
\text { "taste", "overall acceptance"- } \\
\text { treatment time dependent }\end{array}$ & [201] \\
\hline Nonthermal plasma & Corona discharge plasma jet, $3 \mathrm{~min}$ & Pak choi & $\begin{array}{l}\text { Aerobic bacteria } \\
\text { Bacillus cereus } \\
\text { Escherichia coli } \\
\text { Salmonella spp. }\end{array}$ & $\begin{array}{l}\text { On seeds: } 1.3-2.1 \log \mathrm{CFU} / \mathrm{g} \\
\text { reduction-pathogen dependent; } \\
\text { on sprouts: } \sim 2.0 \log \mathrm{CFU} / \mathrm{g} \\
\text { reduction-pathogen dependent }\end{array}$ & $\begin{array}{l}\uparrow \downarrow \text { treatment time } \\
\text { dependent }\end{array}$ & $\begin{array}{l}\downarrow \uparrow \text { yield - treatment time dependent; } \\
\text { not affected reducing sugars, total } \\
\text { phenolics, radical } \\
\text { scavenging activity; } \\
\uparrow \text { slightly "texture"; } \\
\downarrow \text { slightlly "appearance", "taste", } \\
\text { "overall acceptance"-treatment time } \\
\text { dependent }\end{array}$ & [202] \\
\hline Ozone water & $2 \mathrm{ppm}, 5 \mathrm{~min}$ & Alfalfa & Listeria monocytogenes & $\begin{array}{l}\text { On seeds: not effective; } \\
\text { on sprouts: not effective }\end{array}$ & - & - & [184] \\
\hline
\end{tabular}


Table 5. Cont.

\begin{tabular}{|c|c|c|c|c|c|c|c|}
\hline Disinfection Method & Disinfection Conditions & Plant Species & Pathogen/s & Treatment Effectiveness & $\begin{array}{l}\text { Effects on Seed } \\
\text { Germination }\end{array}$ & Effects on Sprouts Yield/Quality & References \\
\hline Plasma-treated water (PTW) & $10 \mathrm{~mL}$ air-PTW & Mung bean & $\begin{array}{l}\text { Natural population of total } \\
\text { bacteria }\end{array}$ & $\begin{array}{l}\text { On sprouts: } 5.2 \log \mathrm{CFU} / \mathrm{g} \\
\text { reduction }\end{array}$ & $\uparrow$ & $\begin{array}{l}\uparrow \text { superoxide dismutase (SOD) } \\
\text { activity, indole acetic acid (IAA) } \\
\text { content; } \\
\downarrow \text { malondialdehyde (MDA) } \\
\text { and abscisic acid (ABA) contents. }\end{array}$ & [203] \\
\hline Ozone & $\begin{array}{l}2000 \mathrm{ppm}, 4 \mathrm{~h} ; \\
4000 \mathrm{ppm}, 2 \mathrm{~h}\end{array}$ & Wheat & Coliforms & $\begin{array}{l}\text { On seeds: }>1.5 \log \mathrm{CFU} / \mathrm{g} \\
\text { reduction }\end{array}$ & Not tested & $\begin{array}{l}\text { Minimum effect on antioxidant } \\
\text { properties, flipid oxidation, moisture } \\
\text { content }\end{array}$ & [204] \\
\hline Ozone & $5 \mathrm{ppm}, 20 \mathrm{~min}$ & Alfalfa & $\begin{array}{l}\text { Salmonella spp. } \\
\text { Shiga toxin-producing } \\
\text { Escherichia coli }\end{array}$ & $\begin{array}{l}\text { On seeds: } 2.1 \log \mathrm{CFU} / \mathrm{g} \\
\text { reduction; } \\
\text { on sprouts: up to } 3.6 \log \mathrm{CFU} / \mathrm{g} \\
\text { reduction-pathogen dependent }\end{array}$ & Not affected & Not affected yield and color & [205] \\
\hline $\begin{array}{l}\text { Ultraviolet irradiation, } \\
\text { krypton-chloride excilamp }\end{array}$ & $222-\mathrm{nm}, 261 \mathrm{~mJ} / \mathrm{cm}^{2}$ & Alfalfa & $\begin{array}{l}\text { Salmonella Typhimurium } \\
\text { Escherichia coli O157:H7 }\end{array}$ & $\begin{array}{l}\text { On seeds: } 2.8-3.0 \log \mathrm{CFU} / \mathrm{g} \\
\text { reduction-pathogen dependent }\end{array}$ & $\begin{array}{l}\downarrow \text { slightly or not } \\
\text { affected }\end{array}$ & - & [206] \\
\hline \multicolumn{8}{|l|}{ Chemical + physical } \\
\hline Dry heat + hydrogen peroxide & $\begin{array}{l}80^{\circ} \mathrm{C}, 24 \mathrm{~h} ; \\
\mathrm{H}_{2} \mathrm{O}_{2}(30 \%) \text { solution }(2 \% v /), 10 \mathrm{~min}\end{array}$ & Alfalfa & Salmonella Typhimurium & $\begin{array}{l}\text { On seeds: } 1.7-3.6 \log \mathrm{CFU} / \mathrm{g} \\
\text { reduction }\end{array}$ & $\uparrow$ & - & [207] \\
\hline $\begin{array}{l}\text { Mild heat }+ \text { hydrogen peroxide } \\
+ \text { acetic acid }\end{array}$ & $\begin{array}{l}60^{\circ} \mathrm{C}, 20 \mathrm{~min} ; \\
4 \%\left(30 \% \text { wow in } \mathrm{H}_{2} \mathrm{O}\right), 15 \mathrm{~min} ; \\
0.2 \%(5 \% \text { distilled white vinegar }), 15 \mathrm{~min}\end{array}$ & Mung bean & $\begin{array}{l}\text { Escherichia coli O157:H7 } \\
\text { Listeria monocytogenes } \\
\text { Salmonella enterica }\end{array}$ & $\begin{array}{l}\text { On seeds: }>4.0 \log \mathrm{CFU} / \mathrm{g} \\
\text { reduction-pathogen dependent; } \\
\text { on sprouts: not effective }\end{array}$ & Not affected & - & [208] \\
\hline $\begin{array}{l}\text { Mild heat + hydrogen peroxide } \\
+ \text { AcOH sanitizing solution }\end{array}$ & $\begin{array}{l}50{ }^{\circ} \mathrm{C}, 10 \mathrm{~min} ; \\
2.0 \% \mathrm{H}_{2} \mathrm{O}_{2}+0.1 \% \mathrm{AcOH} \text { (Pure White } \\
\text { Vinegar), } 10 \mathrm{~min}\end{array}$ & $\begin{array}{l}\text { Alfalfa, } \\
\text { radish }\end{array}$ & $\begin{array}{l}\text { Escherichia coli } \mathrm{O} 157 \mathrm{H7} \\
\text { Listeria monocytogenes } \\
\text { Salmonella enterica }\end{array}$ & $\begin{array}{l}\text { On seeds: } 4.6-5.0 \log \mathrm{CFU} / \mathrm{g} \\
\text { reduction - pathogen } \\
\text { dependent }\end{array}$ & Not affected & Yield not affected & [209] \\
\hline \multicolumn{8}{|l|}{ Biological } \\
\hline Bacteriophages & $\begin{array}{l}\text { Salmonella phage, seed soaking, } 2 \mathrm{~h} \text {, room } \\
\text { temperature }\end{array}$ & Alfalfa & Salmonella enterica & $\begin{array}{l}\text { On seeds: } 2.5 \log \mathrm{CFU} / \mathrm{g} \\
\text { reduction; } \\
\text { on sprouting seeds: reduced } \\
\text { without significance }\end{array}$ & Not affected & Not affected & [211] \\
\hline Bacteriophages & $\begin{array}{l}\text { Escherichia coli O104:H4 phage cocktail, } \\
\text { (i) free phage application: } 2 \mathrm{~mL}\left(2.5 \times 10^{10}\right. \\
\text { plaque--forming units ( (PFU)/mL), } 1 \mathrm{~h} ; \\
\text { (ii) impregnated phage application: filter } \\
\text { paper in } 7 \mathrm{~cm} \text { diameter blotting with } 6 \mathrm{~mL} \\
\left(2.5 \times 10^{10} \mathrm{PFU} / \mathrm{mL}\right) ; \\
\text { (iii) encapsulated phage application: seeds } \\
\text { placed onto the paper coated with } \\
\text { encapsulated phage in alginate beads. }\end{array}$ & Alfalfa & Escherichia coli O104:H4 & $\begin{array}{l}\text { On seeds: below the limits of } \\
\text { detection }(<1.0 \log \mathrm{CFU} / \mathrm{g}) ; \\
\text { on sprouts: } 1-\log \text { cycle } \\
\text { reduction }\end{array}$ & - & - & [212] \\
\hline Non-antagonistic bacterium & $\begin{array}{l}\text { Erwinia persicina EUS78 strain, } 10^{8} \\
\text { colony-forming unit }(\mathrm{CFU}) / \mathrm{mL} \text { seed, dwelling }\end{array}$ & Alfalfa & Salmonella enterica & Not affected & Not affected & - & [213] \\
\hline $\begin{array}{l}\text { Lactobacillus plantarum, } \\
\text { Pediococcus acidilactici and } \\
\text { Pediococcus pentosaceus mixture }\end{array}$ & $7 \log \mathrm{CFU} / \mathrm{g}, 20^{\circ} \mathrm{C}, 5 \mathrm{~d}$ & Alfalfa & $\begin{array}{l}\text { Listeria monocytogenes } \\
\text { Salmonella spp. }\end{array}$ & $\begin{array}{l}1.0-4.5 \log \mathrm{CFU} / \mathrm{g} \\
\text { reduction-depending on } \\
\text { pathogen and initial } \\
\text { concentration }\end{array}$ & Not affected & Not affected & [214] \\
\hline
\end{tabular}


Table 5. Cont

\begin{tabular}{|c|c|c|c|c|c|c|c|}
\hline Disinfection Method & Disinfection Conditions & Plant Species & Pathogen/s & Treatment Effectiveness & $\begin{array}{l}\text { Effects on Seed } \\
\text { Germination }\end{array}$ & Effects on Sprouts Yield/Quality & References \\
\hline \multicolumn{8}{|l|}{ Plant extracts } \\
\hline Benzyl isothiocyanate (BIT) & $1.5-2.0 \%(\mathrm{v} / \mathrm{v}), 15 \mathrm{~min}, 22 \pm 2{ }^{\circ} \mathrm{C}$ & Alfalfa & Salmonella enterica serotypes & $\begin{array}{l}\text { On seeds: }>1.5 \text { and } 0.7 \mathrm{log} \\
\text { CFU/g reduction-serovar } \\
\text { dependent; } \\
\text { on sprouts: } 1.2-2.3 \log \mathrm{CFU} / \mathrm{g} \\
\text { reduction-serovar dependent }\end{array}$ & Not affected & Not tested & [215] \\
\hline Grapefruit seed extract & $0.05 \%$ aqueous solution & Lettuce & $\begin{array}{l}\text { Natural population of total } \\
\text { bacteria }\end{array}$ & Strong seed sterilization effects & Not affected & No effects on texture and color & [216] \\
\hline $\begin{array}{l}\text { Allspice, thyme and rosemary } \\
\text { essential oils }\end{array}$ & $\begin{array}{l}\text { Concentrations variable among species } \\
\text { and pathogens }\end{array}$ & Alfalfa & $\begin{array}{l}\begin{array}{l}\text { Salmonella Typhimurium } \\
\text { Listeria monocytogenes }\end{array} \\
\end{array}$ & Strong seed sterilization effects & Not affected & No effects on sensory properties & [217] \\
\hline $\begin{array}{l}\text { Savory, bay leaf and thyme } \\
\text { hydrosols }\end{array}$ & $40 \mathrm{~min}$ & $\begin{array}{c}\text { Wheat, } \\
\text { lentil, } \\
\text { mung bean }\end{array}$ & $\begin{array}{l}\text { Salmonella Typhimurium } \\
\text { Staphylococcus aureus }\end{array}$ & $\begin{array}{l}\text { Strong seed sterilization } \\
\text { effects-pathogen dependent }\end{array}$ & Not affected & - & [218] \\
\hline
\end{tabular}




\section{Sprouts and Human Health: Rewards and Riddles}

Numerous studies have been conducted to investigate the role of sprouts as functional foods or nutraceuticals [219]. These two terms carry slightly different connotations depending on the jurisdiction of sale, regulatory considerations, and marketing strategies, but largely overlap and are frequently used interchangeably [220]. While functional foods generally imply health benefits in addition to nutritional value, nutraceuticals tend to denote a food (or a part of it) with an impact on prevention and/or treatment of a specific disease or disorder [221].

Sprouts are a good fit for nutrition research due to their wealth of phytochemical content combined with reduced antinutrient levels, and the expression of distinct cohorts of secondary metabolites that are subject to spatiotemporal modes of expression, which may largely diverge from patterns and profiles displayed in seeds and mature plants [219,222,223]. Furthermore, research offers the prospect of substantial rewards, given that products aimed at benefitting human health have progressively gained traction in recent years in response to increasing information and awareness about better eating habits and plant-forward diets, coupled with concerns associated with an aging population at risk of nutrition frailty [224]. Accordingly, markets for functional foods and nutraceuticals are growing globally at a stunning pace, accounting for revenues of US \$174 billion in 2019 (forecasted to US \$275 billion in 2025) for the former and US $\$ 383$ billion in 2017 (forecasted to US $\$ 561$ billion in 2023) for the latter (https://www.statista.com/statistics/591619/global-market-size-nutraceuticals/).

Whether sold for general health purposes or medical applications, claims about health benefits must be supported by rigorous and convincing methods of investigation prior to market launch, which may entail review and subsequent approval by governmental agencies in specific jurisdictions [225]. In this regard, nutrition science can face challenges, given the tension between scientific rigor, profitable business, and conflicting interests in relation to issues such as safety, health benefits, intellectual property, regulatory formats, marketing strategies, and financial affairs [226]. As for other complex sources of macro- and micro-nutrients, and secondary metabolites, the assessment of biological and nutraceutical effects of sprouts on human health is typically based on studies involving cellular systems representing a given phenotypic trait(s), preclinical studies in relevant animal models and, ultimately, human clinical trials. Investigational procedures, in particular cell-based studies, can be greatly facilitated by fast turnaround times to obtain samples, and the ability to enhance the content of specific metabolites using variable elicitation conditions, either abiotic (e.g., temperature, humidity, soil salinity, light intensity) or biotic (e.g., plant hormones, amino acids) [81]. On the other hand, metabolic intensity, biomechanical plasticity, and rapid physiological changes may negatively affect standardization and robustness of experimental conditions and, in turn, reproducibility and accurate interpretation of data.

Cell models generally serve as the biological systems for investigating phenotypic effects, or mechanistically identifying biologically relevant targets and related molecular networks. Within this context, sprouts provide the opportunity for implementing quick, flexible, and versatile procedures to concurrently develop metabolic variants for subsequent characterizations, comparisons to controls, and application of multivariate statistical analyses to discriminate the chemical entities exercising an active role on observed biological effects. By way of example, this rationale was applied by Ferruzza et al. [227] to show a protective effect by Brassica oleracea sprouts against a human model of gut inflammation developed in Caco-2 cells.

Although routinely carried out in many laboratories, tissue culture requires special attention to ensure a phenotypically relevant model for contextual interpretations of experiments, as well as robust and reproducible data. In this regard, the following are important considerations: (1) a specific cell line may exhibit significantly phenotypic variability across different laboratories, and should therefore be authenticated as a first step prior to experimentation [228,229]; (2) culture conditions and passage number should adhere to recommended protocols to avoid or at least minimize genomic and molecular alterations, while recognizing that cell populations are, to some degree, heterogeneous due to the likely presence of slow-cycling stem or progenitor cell subpopulations [230]; (3) primary 
cells grown on plastic (2D cultures) are rapidly subject to phenotypic changes such that they no longer reflect the biology of parental tissues [231]; and (4) cancer cell lines generally double at much higher rates (e.g., 18-24 h) than native tissues and do not represent the phenotypic multiplicity shown by the corresponding patient cohorts [232]. However, co-cultures can offer valid models to assess the effects of nutraceuticals and functional foods in that cell-cell contacts as well as paracrine or juxtacrine interactions are relevant to physiological and pathological environments, and may markedly influence sensitivity to external challenge [233]. This was clearly illustrated when quercetin and genistein, two polyphenols with proven anti-inflammatory properties, were used as positive controls to counteract the inflammatory response provoked by interleukin $1 \beta$ in human pluripotent stem cell-derived endothelial cells (hPSC-EC). Notably, both polyphenols were inactive when tested in these cells, but displayed a powerful anti-inflammatory response when hPSC-EC were co-cultured with their hepatocytic counterpart hPSC-HEP that, unlike hPSC-EC, retains a metabolic capacity to breakdown quercetin and genistein into bioactive molecules [234]. Finally, it should be noted that organoids and 3D cell-based assays, despite technical challenges [235], represent the most recent advance in tissue culture to recapitulate the cellular and biological complexities of tissues and organs. Although already used for screening purposes [236], this technology is still in its infancy and, to our knowledge, not yet employed in nutraceutical screens.

Cruciferous, grain, and legume sprouts have been tested in preclinical and human studies for their preventive and therapeutic benefits across a variety of health and pathological conditions. These investigations, extensively described and critically reviewed $[27,237,238]$, illustrate the typical complexities of food-based trials, particularly with regard to considerations and concerns over regulatory and scientific matters, and debates about the functional and biological significance of experimental data $[225,239]$. In short, the same dilemma exists today as was raised by Clare $\mathrm{M}$. Hasler almost 20 years ago following a 1999 guidance by the Food and Drug Administration [240]; namely, the distinction between emerging evidence and strong scientific agreement by which a product can be marketed as a dietary supplement to enhance nutrition and achieve physiological benefits, or a medical treatment to prevent or attenuate symptoms, or treat a condition. However, scientific rigor can often be questionable and not sufficiently strong to permit accurate conclusions or comparisons. For plant-derived food, including sprouts, the lack of standardized protocols for the preparation and manipulation of the natural matrix is a crucial limitation. Sprouts, in fact, have been used in animal and human studies as a whole, in the form of extracts, and juices, using different amounts and inconsistent dietary regimens within the population appraised [241,242]. Variable conditions can impact bioavailability, while elusive information about liberation, absorption, distribution, metabolism, and excretion (LADME) phases of pharmacokinetics can complicate decisions as to when and for how long a treatment should be considered [243]. For example, when ingestion of broccoli sprouts (100 g/day) was compared to the same daily amount of alfalfa sprouts (used as the placebo) in 40 (1:1 randomized) asthmatic individuals to evaluate anti-inflammatory and physiological improvements, Sudini et al. [244] used a 3-day intervention protocol that, despite having been purposely developed to mitigate variability, proved to be essentially inconclusive. Similarly, no protective effect was shown in a small-case study by Duran et al. [245], where 16 healthy individuals (1:1 randomized) followed a 3-day diet including $200 \mathrm{~g} /$ day of either broccoli or alfalfa sprouts ( $200 \mathrm{~g} /$ day in both cases) prior to exposure to ozone-induced neutrophilic airway inflammation. Conversely, Brown et al. [246] showed that a sulforaphane-enriched extract from broccoli sprouts taken for 14 days by 45 moderately asthmatic patients beneficially impacted the methacholine bronchoconstriction challenge in $60 \%$ of cases, with $20 \%$ of patients negatively affected and the remaining $20 \%$ unresponsive. Notably, while the study from Duran did not identify any change in the expression of NRF2 (Nuclear factor erythroid 2-related factor 2)-dependent genes (known to be induced by sulforaphane), Brown et al. [246] found instead that activation of the NRF2 pathway correlated with bronchoprotective benefits. Overall, these studies show that divergence of key experimental factors, such as quality and quantity of the material used, time of intervention, size of population tested, and endpoint measurements, can lead to inconsistent 
conclusions, further exacerbated by population heterogeneities [247], as well as bi-phasic or hormetic responses commonly raised by bioactive agents including phytochemicals [248]. Landberg et al. [249], for example, advanced the importance of a methodological approach to stratify clinical trial participants based on the integration of different parameters such as genetic (polymorphisms), phenotypic (age, gender, body mass index (BMI), and the gut microbiome) and ADME profiles to define metabolic representations, namely metabotypes, to ultimately strengthen the association between the effect of plant-based food or any of its (semi)purified components and a specific group of individuals, thus, implementing what it could be referred to as personalized or precision nutrition.

\section{Antinutrients and Allergens in Sprouts}

Antinutrients in plant-based foods have been for years a subject of much interest in human health and malnutrition. Briefly, antinutritional factors are defined as compounds or substances, which negatively interfere with the absorption of other nutrients in the diet, causing reduced nutrient intake, digestion, and utilization, and the occurrence of adverse effects. However, like any other bioactive compounds, antinutritional factors can be responsible for a variety of effects, mainly depending on concentrations and the physiology of the subjects exposed $[250,251]$. For example, tannins are generally considered to be antinutrients, but Kumari and Jain [252] observed a useful role in diabetes management. A similar circumstance was shown for phytic acid [253]. Thus, these two cases support Calder's [254] statement "nutrition science would be wise to adopt practices more akin to pharma when evaluating the functional properties and health impacts of foods, nutrients and non-nutrient food components". For a more complete list of major antinutrients and their role in human nutrition, which goes beyond the scope of this review, we recommend the work by Akande et al. [255].

In general, the germination process is known to decrease the concentration of antinutrients in the resulting sprouts. This has been extensively highlighted in the literature for many different species, i.e., green gram, cowpea, lentil and chickpea [256,257], buckwheat [258], quinoa [259], millet [260,261] barley [262], and flaxseeds [263]. In particular, Pal et al. [264] compared the effects of germination, dehulling, and cooking in horse gram, and showed different patterns of nutrient/antinutrient ratios in relation to treatments. In particular, cooking outperformed the natural germination process in lowering the levels of tannins, phytic acid, and trypsin inhibitors in lentils [264]. We must say that while a rich source of literature has shown antioxidant profiles in sprouts, little information is instead available about modifications of antinutrients profile during the germination process. For example, during the germination of common black beans, it was found that while trypsin inhibitors and phytates decrease, levels of phenols, saponins and tannins trend higher [265]. In the same study, the application of a Controlled Pressure-Drop demonstrates to further lowers trypsin inhibitors and extra raises saponin concentration, while it counters the decrease of phytates and the increase of phenols and tannins [265]. Since the biochemical characteristics of sprouted seeds are strictly related to sprouting conditions, different techniques, alone or in combination, could be performed to easily impact antinutritional levels. For example, lowest phytic acid contents were observed in 48h-old chickpea sprouts grown under blue and red lights [266]. Moreover, advances in molecular breeding raise prospects for future breeding programs aimed to select varieties characterized by low levels of antinutrients or toxins.

The allergenic potential of sprouts and its management is an issue of major concern in food science as well. Allergic reactions are generally mediated by proteins that act as antibodies. During sprouting, a deep modification of proteins profile occurs, thus potentially reducing the concentration of allergenic storage proteins. The peanuts case has been well dug: the results of the in-vitro immunoreactivity of the protein Ara $\mathrm{h} 1$ showed that it remains stable in cotyledons and decreases in others epigeic tissues during the germination process [267]. In the meanwhile, whilst the Ara $\mathrm{h} 2$ antigen is decomposed, resveratrol-a bioactive compound that, in-vitro, interferes with the immune reaction to both Ara h 1 and 2-is newly synthesized [268]. A similar process appears in lentils and mung bean, where germination, associated with cotyledon removal reduced immunoreactivity in-vitro by $97 \%$ and $99 \%$, respectively [269]. Resveratrol is a secondary metabolite produced in response to biotic 
or abiotic stresses. Ultrasound application on peanut seeds proved to be an effective solution to increase resveratrol content in related sprouts, as shown by Yu et al. [94], who found amounts that, compared to controls, ranged 1.7-3.3-fold higher. Moreover, ultrasound applications resulted in an accelerated degradation of allergenic proteins, leading concentrations to undetectable levels after 3 days of germination [94]. Ultrasounds at different power levels (from $0 \mathrm{~W}$ to $300 \mathrm{~W}$ ) have also been tested on soybeans seeds, showing that concentrations of allergenic proteins decrease with increasing power of applications after 5 days of sprouting [95]. Soybeans have been also treated with HHP, and the concentration of allergenic proteins resulted lower in sprouts in relation to raw seeds [270].

Although in some cases the consumption of germinated seeds does not cause an allergic reaction as severe as that associated to raw seeds, sprouts can manifest unexpected cross-reactions in sensitive individuals. In mung bean sprouts Vig $\mathrm{r} 6$ and Vig $\mathrm{r} 1$ proteins can activate basophils high concentrations, and cause the same allergic reaction caused by a protein responsible for pollen allergy, namely Bet v 1 [271]. Cross-reactions can also underlie allergic conditions, as shown for peanuts and sprouts of different Leguminosae species. Jensen et al. [272] compared in-vitro the proteic extract of soybean, green pea, blue lupine, mung bean, alfalfa, broad bean and adzuki bean sprouts with peanut proteic extract and showed that the concentration necessary to achieve the same level of histamine release varied by 3 to 6 orders of magnitude, thereby posing a high risk to sensitive subjects.

\section{Sprouts: A Compelling Case for Drug Discovery?}

The biological and pharmacological activities of whole sprouts or their extracts have been extensively investigated at different levels, including preclinical models, and human studies centered on multiple conditions $[27,237,241]$. Despite such a wealth of information, sprouts were never systematically employed to generate natural product collections aimed at selecting bioactive entities applicable to chemical genetics and medicinal chemistry programs. Instead, it would seem that this could be a valuable pursuit as explained below.

Firstly, sprouts can grow quickly, under consistent and controlled conditions within relatively small footprints and confined layouts, and potentially scaled-up for industrial production based on FDA-recommended guidelines [273]. Notably, the opportunity to obtain natural products from sprouts produced via local greenhouse arrangements offers environmental and ethical advantages, by easing concerns around possible insults to sustainable biological diversity arising out of traditional approaches to drug discovery. In fact, after the 1992 United Nations Convention on Biological Diversity (integrated a decade later by the Nagoya Protocol) [274], traditional approaches based on collections of living organisms from different geographical regions and ecosystems have posed challenges in terms of securing international access to natural products as well as sharing intellectual property rights with source countries [275].

Secondly; sprouts, such as plants, stand out for chemical diversity, which may arise as a result of (1) the influence that genetic and environmental factors, and agronomic setups, may have on metabolic homeostasis [276]; (2) chemical sensitivity to elicitation techniques that may be established through a wide array of combinations between germination conditions and abiotic and/or biotic stimuli [4]; and (3) the occurrence of alternative biosynthetic routes in relation to changes in gene expression profiles [277]. Together with the vast number of structural modifications exhibited by plant metabolites [278], such metabolic adaptability can potentially contribute to the expansion of natural product chemistry into the uncharted regions of druggable space, namely, the realm of chemicals that specifically interact with, and modulate, disease-relevant targets [279-283].

Thus, sprouts appear to be a good candidate for the OSMAC (One Strain MAny Compounds) concept, which refers to the rational, systematic modification of culture conditions aimed at maximizing the range of secondary metabolites produced in a given system. Initially described in 2002 [284], the OSMAC rationale was developed to trigger, or unlock, metabolic gene clusters that consistently remain unexpressed under common or standard culture conditions, and successfully applied to fungi, bacteria, and marine microorganisms as primary sources of chemicals for drug research [285]. 
This approach can also be relevant to sprouts, given that genetically clustered metabolic pathways exist in plants, and have been linked to the biosynthesis of bioactive chemicals, such as terpenes, alkaloids, diketones, cyanogenic glucosides, and hydroxamic acid [286]. The investigation of biosynthetic gene clusters in plants using sequencing technologies, bioinformatics tools, and predictive computational solutions [287-291] is a rapidly expanding field leading towards unprecedented possibilities for tapping into unexplored metabolic pathways, identifying new molecules, and uncovering mechanisms of metabolic diversification. In this regard, the dynamic rearrangement of neighboring genes was recently shown in Brassicaceae to rewire triterpene biosynthesis and, consequently, account for triterpene metabolic diversity [292].

Thirdly, the systematic investigation of sprouts in drug discovery programs can be strongly facilitated by major advances in the production of natural product collections [293]; these include, for example, methods of sample extraction, pre-fractionation and drug-like enrichment [294-296]; NMR, MS and related hyphenated techniques for dereplication and unambiguous identification of novel chemicals [297-299]; effective and versatile solutions in high-throughput technologies [300,301]; design, optimization, and miniaturization of cell-free and cell-based screening assays [293]; and, finally, progressively easier access to integrated omics platforms applicable, for example, to target identification programs and mechanistic elucidation of a drug's biological impact, efficacy, and side or adverse effects [302] (Figure 1).

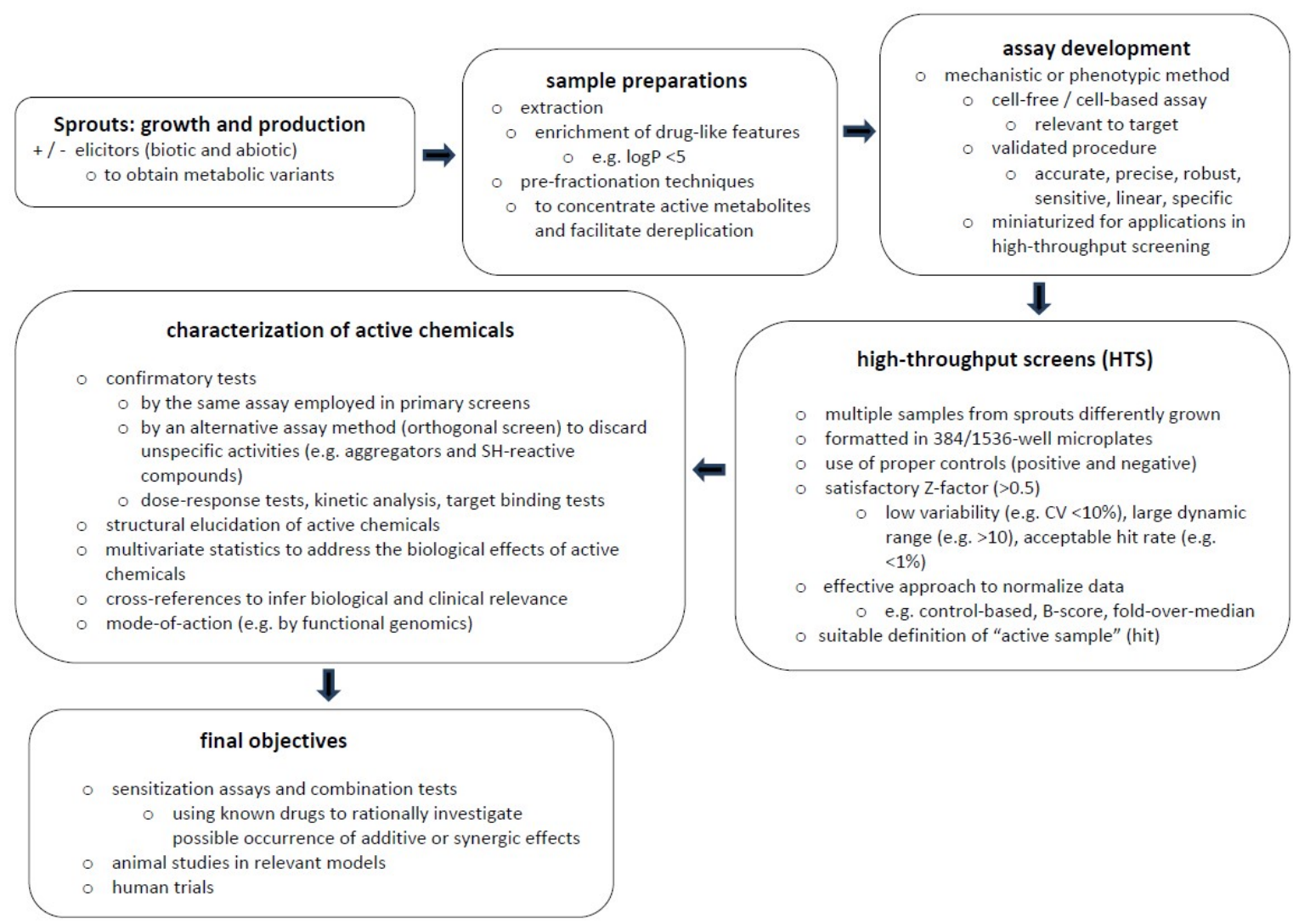

Figure 1. Schematic example of an experimental workflow aimed to select and identify pharmacologically active chemicals from sprouts. 
It is emblematic that in-vitro and in-vivo studies have almost exclusively been carried out using whole sprouts or, at best, fractionated extracts performed by non-standardized protocols [27,241]. This approach, while offering the possibility of uncovering health benefits and nutraceutical properties of functional foods, gives rise to significant challenges in drawing definitive conclusions due, for example, to variability in the production and preparation of the food matrix, dietary regimens and, importantly, the effects caused by interactions between active nutrients, as in the case of polyphenols where a fine line runs between additive, synergic, and antagonistic effects [303-305].

Fourthly, sprouts contain significant amounts of phytochemicals, which have historically been studied in human clinical trials. In this regard, phenolics (and, particularly, flavonoids [306]) and the breakdown products of glucosinolates, isothiocyanates, and indoles [27,242], have been investigated, either singly or combined with other treatments. Although many of these chemicals are very well known and have been comprehensively reviewed, one must note that phenolics account for more than 8000 widely and differentially distributed entities [307], and glucosinolates (both fully and partially characterized) are represented by at least 137 different structures [308] subject as well to genetic and environmental variability [309]. Such extraordinary diversity, combined with a multi-target chemistry shown by polyphenols [310], flavonoids [311], and isothiocyanates [312], may represent novel and significant opportunities to explore, and possibly extend, druggable space [313].

An example of such an opportunity is illustrated by sulforaphane, an isothiocyanate resulting from the hydrolysis of its glucosinolate precursor, glucoraphanin, which is 10-100 times more abundant in broccoli sprouts than the mature plant [314]. Sulforaphane was isolated in 1992 as a cancer chemoprotective inducer of Phase II detoxifying enzymes and used in $>2000$ studies to investigate (1) mechanistic function over the NRF2/ARE axis and downstream activation of hundreds of cytoprotective genes; (2) chemical reactivity and structure-activity relationship (SAR) analyses; (3) pleiotropic roles; (4) biological significance in disparate cellular and animal models; and (5) disease prevention and therapeutic effects in humans (reviewed in [241,315]). In the last 15 years, sulforaphane from broccoli sprouts (introduced in the diet as a whole, or administered in the forms of homogenates, extracts, beverages or caplets) was investigated in $>30$ human trials targeting a large variety of conditions including cancer, inflammation, diabetes, obesity, cardiovascular disease, bacterial and viral infections, respiratory diseases, and neurological disorders [241]. Currently (as of August 24, 2020), 14 such trials are in the recruiting or not-yet-recruiting stage (https://clinicaltrials.gov).

Such keen interest in the molecule's potential can most likely be attributed to its excellent bioavailability $[316,317]$ and an overt plurality of biological effects evidenced by over 200 high-confidence targets observed in breast cancer cells [318] and the potential for hermetic behaviors, as shown in several cell models [319]. While other isothiocyanates have not been studied as extensively as sulforaphane, its polypharmacological behavior may reflect a general signature of these chemicals, based on their chemical structure, lipophilicity, and reactivity [312]. The same can be said for indoles, such as indole-3-carbinol, a glucobrassicin derivative that displays differential effects depending on timing of administration, and its condensation product, 3,3 diindolylmethane, which impacts multiple pathways associated with cancer and inflammation. Notably, both indoles have been tested in human clinical trials, either alone or in combination with other treatments [242].

Polypharmacology is an intriguing point that merits special attention, given a growing consensus in recent years towards a drug discovery shift from the traditional "magic bullet" concept of one drug/one target, to a preference for chemicals that act on multiple molecular targets and effect various downstream functions. This approach, while potentially risky in terms of drug promiscuity and side effects, may nonetheless provide solutions for optimizing drug safety/efficacy and/or conceiving target/therapeutic reposition strategies by omics technologies in system biology (e.g., functional genomics) and cheminformatics [320,321]. 
In summary, sprouts can be pivotal in drug discovery research, well beyond nutritional and nutraceutical prerogatives. Their chemical content is a rich and versatile source of functional ingredients that, when mixed in extracts, display biological activities which, however, may not necessarily reflect the biological potential of purified or semi-purified entities. With the latter, selection of lead candidates can be pursued using either classical or reverse pharmacology (i.e., phenotypicor target-based, respectively), whereas sample extracts are generally limited to phenotypic bioassays where technical difficulties often arise due to the occurrence of false negatives.

As a preliminary step, we carried out a high-throughput screening campaign, using HPLC-prefractionated extracts, to assess whether and to what extent different species of sprouts had an impact on the effects shown by approximately 1000 marketed drugs and 640 kinase inhibitors in a variety of cancer cells lines. Using cytotoxicity as the primary measurement, we found in several instances that phenolics-enriched fractions displayed either synergic or antagonistic effects in presence of several drugs and that, notably, these effects were frequently associated with specific cell types. For example, a markedly cytotoxic effect by Tofacitinib observed in HeLa cells (but not LNCaP cells) was virtually abolished in the presence of specific fractions of maize sprout extract, similar to what known antioxidants (i.e., resveratrol and quercetin), included for comparison purposes, had shown. On the other hand, synergic effects were observed when the same extract was combined with Dovitinib in HeLa cells, and Tivozanib in LNCaP cells (Datti, unpublished results). No effects, instead, were observed when whole extracts were used as a reference, thereby suggesting, in this case, new unexplored avenues to assess the integration of nutritional supplements and dietary habits with anticancer chemotherapeutic treatments.

\section{Sprouts in Animal Feeding}

The use of sprouts to supplement animal feeding can be aimed at maintaining or enhancing animal health as well as transferring phytochemicals to livestock products (milk, meat, eggs), which are subsequently ingested by humans. Through this approach, it is possible to bypass the risks to human health posed by microbiological contamination of raw sprouts. Moreover, sprouts can be integrated into feed rations in seasons when fodder production is limited [322].

Despite a mutual relevance to zootechnics and human nutrition, literature on this field is scant (Table 6). 
Table 6. Livestock species fed with micro-scale vegetables to improve quality and nutritional features of derived products.

\begin{tabular}{|c|c|c|c|c|c|c|}
\hline Livestock & Sprout Species & Sprout Family & Days after Sowing (DAS) & $\begin{array}{l}\text { Effects on Livestock Health } \\
\text { and Products }\end{array}$ & $\begin{array}{l}\text { Phytochemicals Transferred } \\
\text { to Livestock Products }\end{array}$ & References \\
\hline \multicolumn{7}{|l|}{ Poultry } \\
\hline Betagro laying hens & $\begin{array}{l}\text { Brassica oleracea var. } \\
\text { Alboglabra-Chinese kale }\end{array}$ & Brassicaceae & 15 & $\uparrow$ Se content in eggs and tissues & N/A & [323] \\
\hline \multirow[t]{3}{*}{ Japanese quails } & Hordeum vulgare-barley & Poaceae & 7 & $\begin{array}{l}\text { } \text { egg laying rate; } \\
\uparrow \text { relative weights of gizzard and testis; } \\
\uparrow \text { fertility; } \\
\uparrow \text { number of hatched chicks/female; } \\
\text { no effect on egg quality indices }\end{array}$ & N/A & [324] \\
\hline & $\begin{array}{l}\text { Brassica oleracea var. } \\
\text { alboglabra-Chinese kale }\end{array}$ & Brassicaceae & 7 & $\begin{array}{l}\text { No effects on performances and carcass } \\
\text { characteristics; } \\
\uparrow S e \text { content in tissues }\end{array}$ & N/A & {$[325]$} \\
\hline & & & 15 & $\begin{array}{l}\text { Se from sprout does not affect } \\
\text { performances and egg quality; } \\
\uparrow \text { Se content in eggs }\end{array}$ & N/A & {$[326]$} \\
\hline \multirow[t]{2}{*}{ Leghorn hens } & Medicago sativa-alfalfa & Leguminosae & 3 & $\downarrow$ cholesterol content in eggs & $\begin{array}{l}\uparrow \text { isoflavones, antioxidants } \\
\text { and vitamin content in eggs }\end{array}$ & [327] \\
\hline & Linum usitatissimum-flax & Linaceae & 3 & $\downarrow$ cholesterol content in eggs & $\begin{array}{l}\uparrow \text { isoflavones, antioxidants } \\
\text { and vitamin content in eggs }\end{array}$ & {$[327]$} \\
\hline Lohmann Brown hens & $\begin{array}{l}\text { Brassica oleracea var. } \\
\text { alboglabra-Chinese kale }\end{array}$ & Brassicaceae & 7 & $\begin{array}{l}\uparrow \text { Se bioavailability and Se content in } \\
\text { eggs, tissues and plasma }\end{array}$ & N/A & [328] \\
\hline \multicolumn{7}{|l|}{ Rabbits } \\
\hline \multirow[t]{3}{*}{ New Zealand white rabbits } & Medicago sativa-alfalfa & Leguminosae & 3 & $\begin{array}{l}\uparrow n-3 \text { fatty } \\
\text { acid contents of meat }\end{array}$ & $\uparrow$ phytoestrogens in muscles & [329] \\
\hline & Linum usitatissimum-flax & Linaceae & 3 & $\begin{array}{l}\uparrow n-3 \text { fatty } \\
\text { acid contents of meat }\end{array}$ & $\uparrow$ phytoestrogens in muscles & [329] \\
\hline & Hordeum vulgare-barley & Poaceae & 12 & $\begin{array}{l}\text { No adverse effects on performances } \\
\text { and meat characteristics }\end{array}$ & $\mathrm{N} / \mathrm{A}$ & {$[330]$} \\
\hline \multicolumn{7}{|l|}{ Ruminants } \\
\hline Awassi male lambs & Hordeum vulgare - barley & Poaceae & 7 & $\begin{array}{l}\uparrow \text { some rumen characters; } \\
\uparrow \text { most nutrient digestibility; } \\
\uparrow \text { feeding efficiency }\end{array}$ & $\mathrm{N} / \mathrm{A}$ & [331] \\
\hline Barky ewes & Hordeum vulgare-barley & Poaceae & 15 & $\begin{array}{l}\uparrow N D F \text { and ADF digestibility; } \\
\uparrow \text { fat, total solid, ash and energy of milk }\end{array}$ & $\mathrm{N} / \mathrm{A}$ & [332] \\
\hline Rams & Hordeum vulgare-barley & Poaceae & 8 & $\begin{array}{l}\downarrow D M \text { intake; } \\
\uparrow \text { enzyme activity and digestive function }\end{array}$ & $\mathrm{N} / \mathrm{A}$ & [332] \\
\hline
\end{tabular}


Studies about sprouts for livestock feeding initially dealt with Se-enriched species aimed at transferring Se to poultry meats and eggs [323,325,326,328]. Early research aimed at studying nutritional properties of rabbit meat was carried out by Dal Bosco et al. [329], who used alfalfa and flax sprouts, and by Mohsen et al. [330], who used barley sprouts. Both studies demonstrated an increase in rabbit meat quality. Barley sprouts were also used by Helal et al. [332] to feed ewes. Mattioli et al. [327] employed alfalfa and flax sprouts to supplement hen diet, with positive outcomes on hen plasma and egg nutritional quality (lower cholesterol and higher phytochemical content). These first results encourage further studies on (1) combinations between various sprout species and livestock species; (2) the effect of different levels of supplementation; (3) the effect on animal health indicators; and (4) the effect on livestock product quality (meat, milk, eggs).

No studies have been performed relating to sprout supplementation in pigs; however, the positive effects of a flavonoid-enriched diet on pig growth and health give reason to encourage investigations in this species [333].

As regards supplementation levels, since high amounts of fresh sprouts might reduce feed consumption and energy intake, studies are needed to evaluate their use in the form of dried powder or pellet. Mattioli et al. [173] demonstrated that drying, in particular freeze-drying, did not compromise the bioactive compound contents of alfalfa and flax sprouts, and considered this evidence as promising for future research on the effect of different levels of supplementation.

An intriguing research prospect is the potential use of sprouts and microgreens to supplement the diet of pets. Pets tend to be considered family members, thereby inducing owners to search for healthy and nutraceutical foods, both for disease prevention and improving quality of life [334]. As an example, the grass (i.e., 10-15 Days After Sowing, DAS) obtained from barley, wheat, oat, or rye, improperly called "catnip", is said to facilitate cat digestion and regurgitation of hairballs. True catnip (Nepeta cataria), instead, decreases the stress of homebound cats, by stimulating their olfactory system and causing an apparently euphoric reaction [335]. Further research is needed in all pet species using multiple varieties of sprouts. Another possible avenue of study is the use of sprouts to feed insects. The sector of edible insects is rapidly expanding and shows wide research possibilities, including in relation to rearing [336]. All of the foregoing subjects deserve to be investigated using a multidisciplinary approach involving sprout scientists, food technologists, animal dieticians, animal growers, and veterinarians.

\section{Conclusions}

Sprouts and microgreens have been extensively studied in recent years, however several aspects remain under-investigated or unexplored. New research prospects may be focused on the production stage (e.g. genotypic analyses, seed treatments, elicitation techniques, biofortification), post-harvest processing (e.g. seed sanitation, shelf-life extension), the impact on human nutrition and animal feeding and, most intriguingly, drug discovery. Since these areas of investigation may overlap, successful research will be contingent on multi- and inter-disciplinary collaborative efforts.

Author Contributions: Conceptualization P.B. Resources F.S. Writing—original draft preparation A.G., B.F., F.S., A.D., P.B. Writing-review and editing A.G., A.D., P.B. Supervision, P.B. All authors have read and agreed to the published version of the manuscript.

Funding: Work supported in part by a funding program (Ricerca di Base 2018-2020) provided by the University of Perugia to P.B. (project coordinator) and A.D.

Conflicts of Interest: The authors declare no conflict of interest. The funders had no role in the design of the study; in the collection, analyses, or interpretation of data; in the writing of the manuscript, or in the decision to publish the results. 


\section{References}

1. Ebert, A.W. Sprouts, microgreens, and edible flowers: The potential for high value specialty produce in Asia. In Proceedings of the SEAVEG 2012 High Value Vegetables Southeast Asia Prod. Supply Demand, Chiang Mai, Thailand, 16 September 2013; pp. 216-227.

2. Kyriacou, M.C.; Rouphael, Y.; Di Gioia, F.; Kyratzis, A.; Serio, F.; Renna, M.; De Pascale, S.; Santamaria, P. Micro-scale vegetable production and the rise of microgreens. Trends Food Sci. Technol. 2016, 57, $103-115$. [CrossRef]

3. Di Gioia, F.; Renna, M.; Santamaria, P. Sprouts, Microgreens and "Baby Leaf" Vegetables BT-Minimally Processed Refrigerated Fruits and Vegetables; Yildiz, F., Wiley, R.C., Eds.; Springer US: Boston, MA, USA, 2017; pp. $403-432$. ISBN 978-1-4939-7018-6.

4. Benincasa, P.; Falcinelli, B.; Lutts, S.; Stagnari, F.; Galieni, A. Sprouted Grains: A Comprehensive Review. Nutrients 2019, 11, 421. [CrossRef] [PubMed]

5. Renna, M.; Gioia, F.D.; Leoni, B.; Mininni, C.; Santamaria, P. Culinary Assessment of Self-Produced Microgreens as Basic Ingredients in Sweet and Savory Dishes. J. Culin. Sci. Technol. 2017, 15, $126-142$. [CrossRef]

6. Di Gioia, F.; Mininni, C.; Santamaria, P. How to grow microgreens. In Microgreens: Microgreens: Novel Fresh and Functional Food to Explore All the Value of Biodiversity; Di Gioia, F., Santamaria, P., Eds.; ECO-logica: Bari, Italy, 2015; pp. 51-79.

7. Mir, S.A.; Shah, M.A.; Mir, M.M. Microgreens: Production, shelf life, and bioactive components. Crit. Rev. Food Sci. Nutr. 2017, 57, 2730-2736. [CrossRef] [PubMed]

8. Renna, M.; Castellino, M.; Leoni, B.; Paradiso, V.M.; Santamaria, P. Microgreens Production with Low Potassium Content for Patients with Impaired Kidney Function. Nutrients 2018, 10, 675. [CrossRef]

9. Renna, M.; Stellacci, A.M.; Corbo, F.; Santamaria, P. The Use of a Nutrient Quality Score is Effective to Assess the Overall Nutritional Value of Three Brassica Microgreens. Foods 2020, 9, 1226. [CrossRef]

10. Ghoora, M.D.; Babu, D.R.; Srividya, N. Nutrient composition, oxalate content and nutritional ranking of ten culinary microgreens. J. Food Compos. Anal. 2020, 91, 103495. [CrossRef]

11. Waśkiewicz, A.; Muzolf-Panek, M.; Goliński, P. Phenolic Content Changes in Plants Under Salt Stress BT-Ecophysiology and Responses of Plants under Salt Stress; Ahmad, P., Azooz, M.M., Prasad, M.N.V., Eds.; Springer New York: New York, NY, USA, 2013; pp. 283-314. ISBN 978-1-4614-4747-4.

12. Piasecka, A.; Jedrzejczak-Rey, N.; Bednarek, P. Secondary metabolites in plant innate immunity: Conserved function of divergent chemicals. New Phytol. 2015, 206, 948-964. [CrossRef]

13. Bartwal, A.; Mall, R.; Lohani, P.; Guru, S.K.; Arora, S. Role of Secondary Metabolites and Brassinosteroids in Plant Defense Against Environmental Stresses. J. Plant Growth Regul. 2013, 32, 216-232. [CrossRef]

14. Taiz, L.; Zeiger, E. Secondary metabolites and plant defense. Plant Physiol. 2006, 4, 315-344.

15. Deng, Y.; Lu, S. Biosynthesis and Regulation of Phenylpropanoids in Plants. CRC Crit. Rev. Plant Sci. 2017, 36, 257-290. [CrossRef]

16. El Khawand, T.; Courtois, A.; Valls, J.; Richard, T.; Krisa, S. A review of dietary stilbenes: Sources and bioavailability. Phytochem. Rev. 2018, 17, 1007-1029. [CrossRef]

17. Peterson, J.; Dwyer, J.; Adlercreutz, H.; Scalbert, A.; Jacques, P.; McCullough, M.L. Dietary lignans: Physiology and potential for cardiovascular disease risk reduction. Nutr. Rev. 2010, 68, 571-603. [CrossRef] [PubMed]

18. Beran, F.; Köllner, T.G.; Gershenzon, J.; Tholl, D. Chemical convergence between plants and insects: Biosynthetic origins and functions of common secondary metabolites. New Phytol. 2019, 223, 52-67. [CrossRef] [PubMed]

19. Saini, R.K.; Keum, Y.-S. Tocopherols and tocotrienols in plants and their products: A review on methods of extraction, chromatographic separation, and detection. Food Res. Int. 2016, 82, 59-70. [CrossRef]

20. Rattan, R.S. Mechanism of action of insecticidal secondary metabolites of plant origin. Crop Prot. 2010, 29, 913-920. [CrossRef]

21. Shahidi, F.; Ambigaipalan, P. Phenolics and polyphenolics in foods, beverages and spices: Antioxidant activity and health effects-A review. J. Funct. Foods 2015, 18, 820-897. [CrossRef]

22. Sirotkin, A.V.; Harrath, A.H. Phytoestrogens and their effects. Eur. J. Pharmacol. 2014, 741, 230-236. [CrossRef]

23. Fiedor, J.; Burda, K. Potential Role of Carotenoids as Antioxidants in Human Health and Disease. Nutrients 2014, 6, 466-488. [CrossRef] 
24. Ogbe, R.J.; Ochalefu, D.O.; Mafulul, S.G.; Olaniru, O.B. A review on dietary phytosterols: Their occurrence, metabolism and health benefits. Asian J. Plant Sci. Res. 2015, 5, 10-21.

25. Dinkova-Kostova, A.T.; Kostov, R.V. Glucosinolates and isothiocyanates in health and disease. Trends Mol. Med. 2012, 18, 337-347. [CrossRef] [PubMed]

26. Renna, M.; Paradiso, V.M. Ongoing Research on Microgreens: Nutritional Properties, Shelf-Life, Sustainable Production, Innovative Growing and Processing Approaches. Foods 2020, 9, 826. [CrossRef] [PubMed]

27. Abellán, Á.; Domínguez-Perles, R.; Moreno, D.A.; García-Viguera, C. Sorting out the Value of Cruciferous Sprouts as Sources of Bioactive Compounds for Nutrition and Health. Nutrients 2019, 11, 429. [CrossRef] [PubMed]

28. Bianchi, G.; Falcinelli, B.; Tosti, G.; Bocci, L.; Benincasa, P. Taste quality traits and volatile profiles of sprouts and wheatgrass from hulled and non-hulled Triticum species. J. Food Biochem. 2019, 43, e12869. [CrossRef]

29. Caracciolo, F.; El-Nakhel, C.; Raimondo, M.; Kyriacou, M.C.; Cembalo, L.; De Pascale, S.; Rouphael, Y. Sensory Attributes and Consumer Acceptability of 12 Microgreens Species. Agronomy 2020, 10, 1043. [CrossRef]

30. Cooper, R. Re-discovering ancient wheat varieties as functional foods. J. Tradit. Complement. Med. 2015, 5, 138-143. [CrossRef]

31. Frassinetti, S.; Moccia, E.; Caltavuturo, L.; Gabriele, M.; Longo, V.; Bellani, L.; Giorgi, G.; Giorgetti, L. Nutraceutical potential of hemp (Cannabis sativa L.) seeds and sprouts. Food Chem. 2018, 262, 56-66. [CrossRef]

32. Kumar, J.; Kaur, A.; Narang, P. Phytochemical screening and metal binding studies on floral extract of Solanum nigrum. Mater. Today Proc. 2020, 26, 3332-3336. [CrossRef]

33. Nemzer, B.; Al-Taher, F.; Abshiru, N. Phytochemical composition and nutritional value of different plant parts in two cultivated and wild purslane (Portulaca oleracea L.) genotypes. Food Chem. 2020, 320, 126621. [CrossRef]

34. Petropoulos, S.A.; Fernandes, Â.; Dias, M.I.; Pereira, C.; Calhelha, R.; Di Gioia, F.; Tzortzakis, N.; Ivanov, M.; Sokovic, M.; Barros, L.; et al. Wild and Cultivated Centaurea raphanina subsp. mixta: A Valuable Source of Bioactive Compounds. Antioxidants 2020, 9, 314. [CrossRef]

35. Harouna, D.V.; Venkataramana, P.B.; Ndakidemi, P.A.; Matemu, A.O. Under-exploited wild Vigna species potentials in human and animal nutrition: A review. Glob. Food Sec. 2018, 18, 1-11. [CrossRef]

36. Montevecchi, G.; Setti, L.; Olmi, L.; Buti, M.; Laviano, L.; Antonelli, A.; Sgarbi, E. Determination of Free Soluble Phenolic Compounds in Grains of Ancient Wheat Varieties (Triticum sp. pl.) by Liquid Chromatography-Tandem Mass Spectrometry. J. Agric. Food Chem. 2019, 67, 201-212. [CrossRef] [PubMed]

37. Gaba, S.; Perronne, R.; Fried, G.; Gardarin, A.; Bretagnolle, F.; Biju-Duval, L.; Colbach, N.; Cordeau, S.; Fernández-Aparicio, M.; Gauvrit, C.; et al. Response and effect traits of arable weeds in agro-ecosystems: A review of current knowledge. Weed Res. 2017, 57, 123-147. [CrossRef]

38. Butnariu, M.; Samfira, I. Vegetal Metabolomics to Seeds of Galium Aparine. J. Bioequiv. Availab. 2013, 5, e45. [CrossRef]

39. Abbas, M.N.; Rana, S.A.; Shahid, M.; Rana, N.; Mahmood-ul-Hassan, M.; Hussain, M. Chemical evaluation of weed seeds mixed with wheat grains at harvest. J. Anim. Plant Sci. 2012, 22, 283-288.

40. Bano, Y.; Ahmad, S.; Alam, S.P. Study of seed germination behaviour of Solanum nigrum L. J. Indian Bot. Soc. 2019, 98, 85-88. [CrossRef]

41. Senila, L.; Neag, E.; Cadar, O.; Kovacs, M.H.; Becze, A.; Senila, M. Chemical, Nutritional and Antioxidant Characteristics of Different Food Seeds. Appl. Sci. 2020, 10, 1589. [CrossRef]

42. Benincasa, P.; Galieni, A.; Manetta, A.C.; Pace, R.; Guiducci, M.; Pisante, M.; Stagnari, F. Phenolic compounds in grains, sprouts and wheatgrass of hulled and non-hulled wheat species. J. Sci. Food Agric. 2015, 95, 1795-1803. [CrossRef]

43. Li, H.; Deng, Z.; Liu, R.; Zhu, H.; Draves, J.; Marcone, M.; Sun, Y.; Tsao, R. Characterization of phenolics, betacyanins and antioxidant activities of the seed, leaf, sprout, flower and stalk extracts of three Amaranthus species. J. Food Compos. Anal. 2015, 37, 75-81. [CrossRef]

44. Paśko, P.; Bartoń, H.; Zagrodzki, P.; Gorinstein, S.; Fołta, M.; Zachwieja, Z. Anthocyanins, total polyphenols and antioxidant activity in amaranth and quinoa seeds and sprouts during their growth. Food Chem. 2009, 115, 994-998. [CrossRef]

45. Aphalo, P.; Martínez, E.N.; Añón, M.C. Amaranth Sprouts: A Potential Health Promoting and Nutritive Natural Food. Int. J. Food Prop. 2015, 18, 2688-2698. [CrossRef] 
46. Lau, T.Q.; Tang, V.T.H.; Kansedo, J. Influence of Soil and Light Condition on the Growth and Antioxidants Content of Amaranthus Cruentus (Red Amaranth) Microgreen. IOP Conf. Ser. Mater. Sci. Eng. 2019, 495, 12051. [CrossRef]

47. Jan, R.; Saxena, D.C.; Singh, S. Physico-chemical, textural, sensory and antioxidant characteristics of gluten-Free cookies made from raw and germinated Chenopodium (Chenopodium album) flour. LWT Food Sci. Technol. 2016, 71, 281-287. [CrossRef]

48. Jan, R.; Saxena, D.C.; Singh, S. Effect of extrusion variables on antioxidant activity, total phenolic content and dietary fibre content of gluten-free extrudate from germinated Chenopodium (Chenopodium album) flour. Int. J. Food Sci. Technol. 2017, 52, 2623-2630. [CrossRef]

49. Jan, R.; Saxena, D.C.; Singh, S. Comparative study of raw and germinated Chenopodium (Chenopodium album) flour on the basis of thermal, rheological, minerals, fatty acid profile and phytocomponents. Food Chem. 2018, 269, 173-180. [CrossRef]

50. Alvarez-Jubete, L.; Wijngaard, H.; Arendt, E.K.; Gallagher, E. Polyphenol composition and in vitro antioxidant activity of amaranth, quinoa buckwheat and wheat as affected by sprouting and baking. Food Chem. 2010, 119, 770-778. [CrossRef]

51. Laus, M.; Cataldi, M.; Soccio, M.; Alfarano, M.; Amodio, M.; Colelli, G.; Flagella, Z.; Pastore, D. Effect of germination and sprout storage on antioxidant capacity and phenolic content in quinoa (Chenopodium quinoa Willd.). In Proceedings of the SIBV-SIGA Joint Congress Sustainability of agricultural environment: Contributions of Plant Genetics and Physiology, Pisa, Italy, 19-22 September 2017.

52. Fischer, S.; Wilckens, R.; Jara, J.; Aranda, M.; Valdivia, W.; Bustamante, L.; Graf, F.; Obal, I. Protein and antioxidant composition of quinoa (Chenopodium quinoa Willd.) sprout from seeds submitted to water stress, salinity and light conditions. Ind. Crops Prod. 2017, 107, 558-564. [CrossRef]

53. Lazo-Vélez, M.A.; Guajardo-Flores, D.; Mata-Ramírez, D.; Gutiérrez-Uribe, J.A.; Serna-Saldivar, S.O. Characterization and Quantitation of Triterpenoid Saponins in Raw and Sprouted Chenopodium berlandieri spp. (Huauzontle) Grains Subjected to Germination with or without Selenium Stress Conditions. J. Food Sci. 2016, 81, C19-C26. [CrossRef]

54. Harakotr, B.; Srijunteuk, S.; Rithichai, P.; Tabunhan, S. Effects of Light-Emitting Diode Light Irradiance Levels on Yield, Antioxidants and Antioxidant Capacities of Indigenous Vegetable Microgreens. Sci. Technol. Asia 2019, 24, 59-66.

55. Kyriacou, M.C.; El-Nakhel, C.; Pannico, A.; Graziani, G.; Soteriou, G.A.; Giordano, M.; Palladino, M.; Ritieni, A.; De Pascale, S.; Rouphael, Y. Phenolic Constitution, Phytochemical and Macronutrient Content in Three Species of Microgreens as Modulated by Natural Fiber and Synthetic Substrates. Antioxidants 2020, 9 , 252. [CrossRef]

56. Kyriacou, M.C.; El-Nakhel, C.; Graziani, G.; Pannico, A.; Soteriou, G.A.; Giordano, M.; Ritieni, A.; De Pascale, S.; Rouphael, Y. Functional quality in novel food sources: Genotypic variation in the nutritive and phytochemical composition of thirteen microgreens species. Food Chem. 2019, 277, 107-118. [CrossRef] [PubMed]

57. Enache, I.-M.; Livadariu, O. Preliminary results regarding the testing of treatments with lightemitting diode (LED) on the seed germination of Artemisia dracunculus L. Sci. Bull. Ser. F. Biotechnol. 2016, 20, 51-56.

58. Lenzi, A.; Orlandini, A.; Bulgari, R.; Ferrante, A.; Bruschi, P. Antioxidant and Mineral Composition of Three Wild Leafy Species: A Comparison Between Microgreens and Baby Greens. Foods 2019, 8, 487. [CrossRef] [PubMed]

59. Pająk, P.; Socha, R.; Broniek, J.; Królikowska, K.; Fortuna, T. Antioxidant properties, phenolic and mineral composition of germinated chia, golden flax, evening primrose, phacelia and fenugreek. Food Chem. 2019, 275, 69-76. [CrossRef]

60. Paradiso, V.M.; Castellino, M.; Renna, M.; Gattullo, C.E.; Calasso, M.; Terzano, R.; Allegretta, I.; Leoni, B.; Caponio, F.; Santamaria, P. Nutritional characterization and shelf-life of packaged microgreens. Food Funct. 2018, 9, 5629-5640. [CrossRef]

61. Bennett, R.N.; Carvalho, R.; Mellon, F.A.; Eagles, J.; Rosa, E.A.S. Identification and Quantification of Glucosinolates in Sprouts Derived from Seeds of Wild Eruca sativa L. (Salad Rocket) and Diplotaxis tenuifolia L. (Wild Rocket) from Diverse Geographical Locations. J. Agric. Food Chem. 2007, 55, 67-74. [CrossRef] 
62. Loedolff, B.; Brooks, J.; Stander, M.; Peters, S.; Kossmann, J. High light bio-fortification stimulates de novo synthesis of resveratrol in Diplotaxis tenuifolia (wild rocket) micro-greens. Funct. Foods Heal. Dis. 2017, 7, 859-872. [CrossRef]

63. Xu, L.; Wang, P.; Ali, B.; Yang, N.; Chen, Y.; Wu, F.; Xu, X. Changes of the phenolic compounds and antioxidant activities in germinated adlay seeds. J. Sci. Food Agric. 2017, 97, 4227-4234. [CrossRef]

64. Chen, Z.; Yu, L.; Wang, X.; Gu, Z.; Beta, T. Changes of phenolic profiles and antioxidant activity in canaryseed (Phalaris canariensis L.) during germination. Food Chem. 2016, 194, 608-618. [CrossRef]

65. Falcinelli, B.; Benincasa, P.; Calzuola, I.; Gigliarelli, L.; Lutts, S.; Marsili, V. Phenolic Content and Antioxidant Activity in Raw and Denatured Aqueous Extracts from Sprouts and Wheatgrass of Einkorn and Emmer Obtained under Salinity. Molecules 2017, 22, 2132. [CrossRef]

66. Stagnari, F.; Galieni, A.; D’Egidio, S.; Falcinelli, B.; Pagnani, G.; Pace, R.; Pisante, M.; Benincasa, P. Effects of sprouting and salt stress on polyphenol composition and antiradical activity of einkorn, emmer and durum wheat. Ital. J. Agron. 2017, 12. [CrossRef]

67. Benincasa, P.; Tosti, G.; Farneselli, M.; Maranghi, S.; Bravi, E.; Marconi, O.; Falcinelli, B.; Guiducci, M. Phenolic content and antioxidant activity of einkorn and emmer sprouts and wheatgrass obtained under different radiation wavelengths. Ann. Agric. Sci. 2020. [CrossRef]

68. Chu, C.; Yan, N.; Du, Y.; Liu, X.; Chu, M.; Shi, J.; Zhang, H.; Liu, Y.; Zhang, Z. iTRAQ-based proteomic analysis reveals the accumulation of bioactive compounds in Chinese wild rice (Zizania latifolia) during germination. Food Chem. 2019, 289, 635-644. [CrossRef] [PubMed]

69. Sritongtae, B.; Sangsukiam, T.; Morgan, M.R.A.; Duangmal, K. Effect of acid pretreatment and the germination period on the composition and antioxidant activity of rice bean (Vigna umbellata). Food Chem. 2017, 227, 280-288. [CrossRef] [PubMed]

70. Peykarestan, B.; Seify, M.; Shoukat-Fadaei, M.; Hatim, M. UV irradiation effects on seed germination and growth, protein content, peroxidase and protease activity in Portulaca grandiflora and Portula caoleracea. World Appl. Sci. J. 2012, 17, 802-808.

71. Gunenc, A.; Rowland, O.; Xu, H.; Marangoni, A.; Hosseinian, F. Portulaca oleracea seeds as a novel source of alkylresorcinols and its phenolic profiles during germination. LWT 2019, 101, 246-250. [CrossRef]

72. Villacís-Chiriboga, J.; Elst, K.; Van Camp, J.; Vera, E.; Ruales, J. Valorization of byproducts from tropical fruits: Extraction methodologies, applications, environmental, and economic assessment: A review (Part 1: General overview of the byproducts, traditional biorefinery practices, and possible applications). Compr. Rev. Food Sci. Food Saf. 2020, 19, 405-447. [CrossRef]

73. Montoya, C.; GonzÃ $j$ lez, L.; Pulido, S.; AtehortÃ \textordmasculinea, L.; Robledo, S.M. Identification and quantification of limonoid aglycones content of Citrus seeds. Rev. Bras. Farmacogn. 2019, 29, 710-714. [CrossRef]

74. Silva, S.; Gomes, L.; Leitão, F.; Bronze, M.; Coelho, A.V.; Boas, L.V. Secoiridoids in olive seed: Characterization of nüzhenide and 11-methyl oleosides by liquid chromatography with diode array and mass spectrometry. Grasas y aceites 2010, 61, 157-164. [CrossRef]

75. González-Hidalgo, I.; Bañón, S.; Ros, J.M. Evaluation of table olive by-product as a source of natural antioxidants. Int. J. Food Sci. Technol. 2012, 47, 674-681. [CrossRef]

76. Weidner, S.; Brosowska-Arendt, W.; Szczechura, W.; Karamac, M.; Kosinska, A.; Amarowicz, R. Effect of osmotic stress and post-stress recovery on the content of phenolics and properties of antioxidants in germinating seeds of grapevine Vitis californica. Acta Soc. Bot. Pol. 2011, 80, 11-19. [CrossRef]

77. Weidner, S.; Chrzanowski, S.; Karamać, M.; Król, A.; Badowiec, A.; Mostek, A.; Amarowicz, R. Analysis of Phenolic Compounds and Antioxidant Abilities of Extracts from Germinating Vitis californica Seeds Submitted to Cold Stress Conditions and Recovery after the Stress. Int. J. Mol. Sci. 2014, 15, 16211-16225. [CrossRef] [PubMed]

78. Falcinelli, B.; Marconi, O.; Maranghi, S.; Lutts, S.; Rosati, A.; Famiani, F.; Benincasa, P. Effect of Genotype on the Sprouting of Pomegranate (Punica granatum L.) Seeds as a Source of Phenolic Compounds from Juice Industry by-Products. Plant Foods Hum. Nutr. 2017, 72, 432-438. [CrossRef] [PubMed]

79. Falcinelli, B.; Maranghi, S.; Paoletti, A.; Marconi, O.; Rosati, A.; Famiani, F.; Benincasa, P. Sprouting olive (Olea europaea L.) seeds as a source of antioxidants from residual whole stones. Sci. Hortic. 2018, 240, 558-560. [CrossRef] 
80. Falcinelli, B.; Famiani, F.; Paoletti, A.; D’Egidio, S.; Stagnari, F.; Galieni, A.; Benincasa, P. Phenolic Compounds and Antioxidant Activity of Sprouts from Seeds of Citrus Species. Agriculture 2020, 10, 33. [CrossRef]

81. Liu, H.; Kang, Y.; Zhao, X.; Liu, Y.; Zhang, X.; Zhang, S. Effects of elicitation on bioactive compounds and biological activities of sprouts. J. Funct. Foods 2019, 53, 136-145. [CrossRef]

82. D'Amato, R.; Regni, L.; Falcinelli, B.; Mattioli, S.; Benincasa, P.; Dal Bosco, A.; Pacheco, P.; Proietti, P.; Troni, E.; Santi, C.; et al. Current Knowledge on Selenium Biofortification to Improve the Nutraceutical Profile of Food: A Comprehensive Review. J. Agric. Food Chem. 2020, 68, 4075-4097. [CrossRef]

83. Hassini, I.; Baenas, N.; Moreno, D.A.; Carvajal, M.; Boughanmi, N.; Martinez Ballesta, M.D.C. Effects of seed priming, salinity and methyl jasmonate treatment on bioactive composition of Brassica oleracea var. capitata (white and red varieties) sprouts. J. Sci. Food Agric. 2017, 97, 2291-2299. [CrossRef]

84. Hassini, I.; Martinez-Ballesta, M.C.; Boughanmi, N.; Moreno, D.A.; Carvajal, M. Improvement of broccoli sprouts (Brassica oleracea L. var. italica) growth and quality by $\mathrm{KCl}$ seed priming and methyl jasmonate under salinity stress. Sci. Hortic. 2017, 226, 141-151. [CrossRef]

85. Baenas, N.; Villaño, D.; García-Viguera, C.; Moreno, D.A. Optimizing elicitation and seed priming to enrich broccoli and radish sprouts in glucosinolates. Food Chem. 2016, 204, 314-319. [CrossRef]

86. Lutts, S.; Benincasa, P.; Wojtyla, L.; Kubala, S.; Pace, R.; Lechowska, K.; Quinet, M.; Garnczarska, M. Seed priming: New comprehensive approaches for an old empirical technique. New Chall. Seed Biol. Transl. Res. Driv. Seed Technol. 2016, 1-46. [CrossRef]

87. Benincasa, P.; D’Amato, R.; Falcinelli, B.; Troni, E.; Fontanella, M.C.; Frusciante, S.; Guiducci, M.; Beone, G.M.; Businelli, D.; Diretto, G. Grain Endogenous Selenium and Moderate Salt Stress Work as Synergic Elicitors in the Enrichment of Bioactive Compounds in Maize Sprouts. Agronomy 2020, 10, 735. [CrossRef]

88. Puccinelli, M.; Malorgio, F.; Rosellini, I.; Pezzarossa, B. Production of selenium-biofortified microgreens from selenium-enriched seeds of basil. J. Sci. Food Agric. 2019, 99, 5601-5605. [CrossRef] [PubMed]

89. Miryeganeh, M.; Saze, H. Epigenetic inheritance and plant evolution. Popul. Ecol. 2020, 62, 17-27. [CrossRef]

90. Marconi, G.; Pace, R.; Traini, A.; Raggi, L.; Lutts, S.; Chiusano, M.; Guiducci, M.; Falcinelli, M.; Benincasa, P.; Albertini, E. Use of MSAP Markers to Analyse the Effects of Salt Stress on DNA Methylation in Rapeseed (Brassica napus var. oleifera). PLoS ONE 2013, 8, e75597. [CrossRef] [PubMed]

91. Vargas-Hernandez, M.; Macias-Bobadilla, I.; Guevara-Gonzalez, R.G.; Romero-Gomez, S.J.; Rico-Garcia, E.; Ocampo-Velazquez, R.V.; Alvarez-Arquieta, L.L.; Torres-Pacheco, I. Plant Hormesis Management with Biostimulants of Biotic Origin in Agriculture. Front. Plant Sci. 2017, 8, 1762. [CrossRef] [PubMed]

92. Aisyah, S.; Gruppen, H.; Madzora, B.; Vincken, J.-P. Modulation of Isoflavonoid Composition of Rhizopus oryzae Elicited Soybean (Glycine max) Seedlings by Light and Wounding. J. Agric. Food Chem. 2013, 61, 8657-8667. [CrossRef]

93. Ampofo, J.O.; Ngadi, M. Ultrasonic assisted phenolic elicitation and antioxidant potential of common bean (Phaseolus vulgaris) sprouts. Ultrason. Sonochem. 2020, 64, 104974. [CrossRef]

94. Yu, M.; Liu, H.; Shi, A.; Liu, L.; Wang, Q. Preparation of resveratrol-enriched and poor allergic protein peanut sprout from ultrasound treated peanut seeds. Ultrason. Sonochem. 2016, 28, 334-340. [CrossRef]

95. Yang, H.; Gao, J.; Yang, A.; Chen, H. The ultrasound-treated soybean seeds improve edibility and nutritional quality of soybean sprouts. Food Res. Int. 2015, 77, 704-710. [CrossRef]

96. Cai, W.; He, H.; Zhu, S.; Wang, N. Biological Effect of Audible Sound Control on Mung Bean (Vigna radiate) Sprout. Biomed Res. Int. 2014, 2014, 931740. [CrossRef] [PubMed]

97. Zuverza-Mena, N.; Armendariz, R.; Peralta-Videa, J.R.; Gardea-Torresdey, J.L. Effects of Silver Nanoparticles on Radish Sprouts: Root Growth Reduction and Modifications in the Nutritional Value. Front. Plant Sci. 2016, 7, 90. [CrossRef] [PubMed]

98. Vicas, S.I.; Cavalu, S.; Laslo, V.; Tocai, M.; Costea, T.O.; Moldovan, L. Growth, Photosynthetic Pigments, Phenolic, Glucosinolates Content and Antioxidant Capacity of Broccoli Sprouts in Response to Nanoselenium Particles Supply. Not. Bot. Horti Agrobot. Cluj-Napoca 2019, 47, 821-828. [CrossRef]

99. Mhamdi, A.; Noctor, G. High $\mathrm{CO}_{2}$ Primes Plant Biotic Stress Defences through Redox-Linked Pathways. Plant Physiol. 2016, 172, 929-942. [CrossRef] [PubMed]

100. Eissa, N.H.; Zayed, M.S.; Hassanein, M.K.; Abdallah, M.M.F. Green pea sprout response to microbial inoculation and increasing atmospheric CO2 concentration. Arab. Univ. J. Agric. Sci. 2018, 26, 2513-2523. [CrossRef] 
101. Chen, Y.-P.; He, J.-M.; Li, R. Effects of magnetic fields pretreatment of mungbean seeds on sprout yield and quality. Afr. J. Biotechnol. 2012, 11, 8932-8937.

102. Wang, S.; Wang, J.; Guo, Y. Microwave irradiation enhances the germination rate of tartary buckwheat and content of some compounds in its sprouts. Polish J. food Nutr. Sci. 2018, 68, 195-205. [CrossRef]

103. Kumar, S.; Gautam, S. A combination process to ensure microbiological safety, extend storage life and reduce anti-nutritional factors in legume sprouts. Food Biosci. 2019, 27, 18-29. [CrossRef]

104. Alrifai, O.; Hao, X.; Marcone, M.F.; Tsao, R. Current Review of the Modulatory Effects of LED Lights on Photosynthesis of Secondary Metabolites and Future Perspectives of Microgreen Vegetables. J. Agric. Food Chem. 2019, 67, 6075-6090. [CrossRef]

105. Bartucca, M.L.; Del Buono, D.; Ballerini, E.; Benincasa, P.; Falcinelli, B.G.M. Effect of light spectrum on gas exchange, growth and biochemical characteristics of einkorn seedlings. Agronomy 2020, 10, 1042. [CrossRef]

106. Kyriacou, M.C.; El-Nakhel, C.; Pannico, A.; Graziani, G.; Soteriou, G.A.; Giordano, M.; Zarrelli, A.; Ritieni, A.; De Pascale, S.; Rouphael, Y. Genotype-Specific Modulatory Effects of Select Spectral Bandwidths on the Nutritive and Phytochemical Composition of Microgreens. Front. Plant Sci. 2019, 10, 1501. [CrossRef] [PubMed]

107. Kyriacou, M.C.; De Pascale, S.; Kyratzis, A.; Rouphael, Y. Microgreens as a Component of Space Life Support Systems: A Cornucopia of Functional Food. Front. Plant Sci. 2017, 8, 1587. [CrossRef] [PubMed]

108. Nakajima, S.; Shiraga, K.; Suzuki, T.; Kondo, N.; Ogawa, Y. Chlorophyll, Carotenoid and Anthocyanin Accumulation in Mung Bean Seedling Under Clinorotation. Microgravity Sci. Technol. 2017, 29, 427-432. [CrossRef]

109. Falcinelli, B.; Sileoni, V.; Marconi, O.; Perretti, G.; Quinet, M.; Lutts, S.; Benincasa, P. Germination under Moderate Salinity Increases Phenolic Content and Antioxidant Activity in Rapeseed (Brassica napus var oleifera Del.) Sprouts. Molecules 2017, 22, 1377. [CrossRef]

110. Aisyah, S.; Gruppen, H.; Slager, M.; Helmink, B.; Vincken, J.-P. Modification of Prenylated Stilbenoids in Peanut (Arachis hypogaea) Seedlings by the Same Fungi That Elicited Them: The Fungus Strikes Back. J. Agric. Food Chem. 2015, 63, 9260-9268. [CrossRef] [PubMed]

111. Aisyah, S.; Gruppen, H.; Andini, S.; Bettonvil, M.; Severing, E.; Vincken, J.-P. Variation in accumulation of isoflavonoids in Phaseoleae seedlings elicited by Rhizopus. Food Chem. 2016, 196, 694-701. [CrossRef]

112. Aisyah, S.; Vincken, J.-P.; Andini, S.; Mardiah, Z.; Gruppen, H. Compositional changes in (iso)flavonoids and estrogenic activity of three edible Lupinus species by germination and Rhizopus-elicitation. Phytochemistry 2016, 122, 65-75. [CrossRef]

113. Araya-Cloutier, C.; den Besten, H.M.W.; Aisyah, S.; Gruppen, H.; Vincken, J.-P. The position of prenylation of isoflavonoids and stilbenoids from legumes (Fabaceae) modulates the antimicrobial activity against Gram positive pathogens. Food Chem. 2017, 226, 193-201. [CrossRef]

114. Andini, S.; Dekker, P.; Gruppen, H.; Araya-Cloutier, C.; Vincken, J.-P. Modulation of Glucosinolate Composition in Brassicaceae Seeds by Germination and Fungal Elicitation. J. Agric. Food Chem. 2019, 67, 12770-12779. [CrossRef]

115. de Bruijn, W.J.C.; Vincken, J.-P.; Duran, K.; Gruppen, H. Mass Spectrometric Characterization of Benzoxazinoid Glycosides from Rhizopus-Elicited Wheat (Triticum aestivum) Seedlings. J. Agric. Food Chem. 2016, 64, 6267-6276. [CrossRef]

116. Shalaby, S.; Horwitz, B.A. Plant phenolic compounds and oxidative stress: Integrated signals in fungal-plant interactions. Curr. Genet. 2015, 61, 347-357. [CrossRef] [PubMed]

117. Swieca, M.; Gawlik-Dziki, U.; Jakubczyk, A.; Bochnak, J.; Sikora, M.; Suliburska, J. Nutritional quality of fresh and stored legumes sprouts - Effect of Lactobacillus plantarum 299v enrichment. Food Chem. 2019, 288, 325-332. [CrossRef] [PubMed]

118. Swieca, M.; Kordowska-Wiater, M.; Pytka, M.; Gawlik-Dziki, U.; Seczyk, L.; Złotek, U.; Kapusta, I. Nutritional and pro-health quality of lentil and adzuki bean sprouts enriched with probiotic yeast Saccharomyces cerevisiae var. boulardii. LWT 2019, 100, 220-226. [CrossRef]

119. Złotek, U.; Świeca, M.; Reguła, J.; Jakubczyk, A.; Sikora, M.; Gawlik-Dziki, U.; Kapusta, I. Effects of probiotic L. plantarum $299 \mathrm{v}$ on consumer quality, accumulation of phenolics, antioxidant capacity and biochemical changes in legume sprouts. Int. J. Food Sci. Technol. 2019, 54, 2437-2446. [CrossRef] 
120. Briatia, X.; Jomduang, S.; Park, C.H.; Lumyong, S.; Kanpiengjai, A.; Khanongnuch, C. Enhancing growth of buckwheat sprouts and microgreens by endophytic bacterium inoculation. Int. J. Agric. Biol. 2017, 19, 374-380. [CrossRef]

121. Rouphael, Y.; Colla, G. Editorial: Biostimulants in Agriculture. Front. Plant Sci. 2020, 11, 40. [CrossRef]

122. du Jardin, P. Plant biostimulants: Definition, concept, main categories and regulation. Sci. Hortic. 2015, 196, 3-14. [CrossRef]

123. Witkowicz, R.; Biel, W.; Chłopicka, J.; Galanty, A.; Gleń-Karolczyk, K.; Skrzypek, E.; Krupa, M. Biostimulants and Microorganisms Boost the Nutritional Composition of Buckwheat (Fagopyrum esculentum Moench) Sprouts. Agronomy 2019, 9, 469. [CrossRef]

124. Das, A.; Lee, S.-H.; Hyun, T.K.; Kim, S.-W.; Kim, J.-Y. Plant volatiles as method of communication. Plant Biotechnol. Rep. 2013, 7, 9-26. [CrossRef]

125. Świeca, M.; Gawlik-Dziki, U.; Złotek, U.; Kapusta, I.; Kordowska-Wiater, M.; Baraniak, B. Effect of cold storage on the potentially bioaccessible isoflavones and antioxidant activities of soybean sprouts enriched with Lactobacillus plantarum 299v. LWT 2020, 118, 108820. [CrossRef]

126. Zhao, J.L.; Zou, L.; Zhong, L.Y.; Peng, L.X.; Ying, P.L.; Tan, M.L.; Zhao, G. Effects of polysaccharide elicitors from endophytic Bionectria pityrodes Fat6 on the growth and flavonoid production in tartary buckwheat sprout cultures. Cereal Res. Commun. 2015, 43, 661-671. [CrossRef]

127. Gawlik-Dziki, U.; Dziki, D.; Pietrzak, W.; Nowak, R. Phenolic acids prolife and antioxidant properties of bread enriched with sprouted wheat flour. J. Food Biochem. 2017, 41, e12386. [CrossRef]

128. Ding, H.; Fu, T.-J.; Smith, M.A. Microbial Contamination in Sprouts: How Effective Is Seed Disinfection Treatment? J. Food Sci. 2013, 78, R495-R501. [CrossRef] [PubMed]

129. Warriner, K.; Smal, B. Chapter 11-Microbiological Safety of Sprouted Seeds: Interventions and Regulations. In The Produce Contamination Problem, 2nd ed.; Matthews, K.R., Sapers, G.M., Gerba, C.P., Eds.; Academic Press: San Diego, CA, USA, 2014; pp. 237-268. ISBN 978-0-12-404611-5.

130. Riggio, G.M.; Wang, Q.; Kniel, K.E.; Gibson, K.E. Microgreens-A review of food safety considerations along the farm to fork continuum. Int. J. Food Microbiol. 2019, 290, 76-85. [CrossRef] [PubMed]

131. NSW Food Authority. Products Food Safety Scheme Periodic Review of the Risk; 2019. Available online: https://www.foodauthority.nsw.gov.au/media/4881 (accessed on 27 August 2020).

132. Jin, H.; Craig, D.; Blenman, P.; Yates, A.; Crerar, S.; Healy, M.; Jin, H.; Craig, D.; Blenman, P.; Yates, A.; et al. A Through-chain Analysis of Food Safety Hazards and Control Measures Associated with the Production and Supply of Seed Sprouts for Human Consumption. Eur. J. Nutr. Food Saf. 2014, 4, 424-428. [CrossRef]

133. EFSA Panel on Biological Hazards (BIOHAZ) Scientific Opinion on the risk posed by Shiga toxin-producing Escherichia coli (STEC) and other pathogenic bacteria in seeds and sprouted seeds. EFSA J. 2011, 9, 2424. [CrossRef]

134. Jablasone, J.; Warriner, K.; Griffiths, M. Interactions of Escherichia coli O157:H7, Salmonella typhimurium and Listeria monocytogenes plants cultivated in a gnotobiotic system. Int. J. Food Microbiol. 2005, 99, 7-18. [CrossRef]

135. Symes, S.; Goldsmith, P.; Haines, H. Microbiological Safety and Food Handling Practices of Seed Sprout Products in the Australian State of Victoria. J. Food Prot. 2015, 78, 1387-1391. [CrossRef]

136. Jin, H.; Yates, A.; Craig, D.; Blenman, P.; Crerar, S.A. Through-chain Analysis of Microbiological Food Safety Hazards and Control Measures Associated with Production and Supply of Seed Sprouts for Human Consumption. In Current Trends in Food Science Vol.1; Khader, V., Ed.; Book Publisher International: London, UK, 2019; pp. 57-71, Print; ISBN1 978-81-940613-5-9. eBook; ISBN2 978-93-89246-32-2.

137. Liu, D.; Cui, Y.; Walcott, R.; Díaz-Pérez, J.; Tishchenko, V.; Chen, J. Transmission of human enteric pathogens from artificially-inoculated flowers to vegetable sprouts/seedlings developed via contaminated seeds. Food Control 2019, 99, 21-27. [CrossRef]

138. Praeger, U.; Herppich, W.B.; Hassenberg, K. Aqueous chlorine dioxide treatment of horticultural produce: Effects on microbial safety and produce quality-A review. Crit. Rev. Food Sci. Nutr. 2018, 58, 318-333. [CrossRef]

139. Santos, C.S.; Silva, B.; Valente, L.M.P.; Gruber, S.; Vasconcelos, M.W. The Effect of Sprouting in Lentil (Lens culinaris) Nutritional and Microbiological Profile. Foods 2020, 9, 400. [CrossRef] 
140. Wright, K.M.; Holden, N.J. Quantification and colonisation dynamics of Escherichia coli O157:H7 inoculation of microgreens species and plant growth substrates. Int. J. Food Microbiol. 2018, 273, 1-10. [CrossRef] [PubMed]

141. Baker, K.A.; Beecher, L.; Northcutt, J.K. Effect of irrigation water source and post-harvest washing treatment on the microflora of alfalfa and mung bean sprouts. Food Control 2019, 100, 151-157. [CrossRef]

142. Turner, E.R.; Luo, Y.; Buchanan, R.L. Microgreen nutrition, food safety, and shelf life: A review. J. Food Sci. 2020, 85, 870-882. [CrossRef] [PubMed]

143. Aruscavage, D.; Miller, S.A.; Lewis Ivey, M.L.; Lee, K.E.N.; Lejeune, J.T. Survival and Dissemination of Escherichia coli O157:H7 on Physically and Biologically Damaged Lettuce Plants. J. Food Prot. 2008, 71, 2384-2388. [CrossRef] [PubMed]

144. Işık, H.; Topalcengiz, Z.; Güner, S.; Aksoy, A. Generic and Shiga toxin-producing Escherichia coli (O157:H7) contamination of lettuce and radish microgreens grown in peat moss and perlite. Food Control 2020, 111, 107079. [CrossRef]

145. Reed, E.; Ferreira, C.M.; Bell, R.; Brown, E.W.; Zheng, J. Plant-Microbe and Abiotic Factors Influencing Salmonella Survival and Growth on Alfalfa Sprouts and Swiss Chard Microgreens. Appl. Environ. Microbiol. 2018, 84. [CrossRef] [PubMed]

146. Di Gioia, F.; De Bellis, P.; Mininni, C.; Santamaria, P.; Serio, F. Physicochemical, agronomical and microbiological evaluation of alternative growing media for the production of rapini (Brassica rapa L.) microgreens. J. Sci. Food Agric. 2017, 97, 1212-1219. [CrossRef]

147. Sun, J.; Kou, L.; Geng, P.; Huang, H.; Yang, T.; Luo, Y.; Chen, P. Metabolomic Assessment Reveals an Elevated Level of Glucosinolate Content in $\mathrm{CaCl} 2$ Treated Broccoli Microgreens. J. Agric. Food Chem. 2015, 63, 1863-1868. [CrossRef]

148. Lu, Y.; Dong, W.; Alcazar, J.; Yang, T.; Luo, Y.; Wang, Q.; Chen, P. Effect of preharvest CaCl2 spray and postharvest UV-B radiation on storage quality of broccoli microgreens, a richer source of glucosinolates. J. Food Compos. Anal. 2018, 67, 55-62. [CrossRef]

149. Bonasia, A.; Conversa, G.; Lazzizera, C.; Elia, A. Post-harvest performance of ready-to-eat wild rocket salad as affected by growing period, soilless cultivation system and genotype. Postharvest Biol. Technol. 2019, 156, 110909. [CrossRef]

150. Sikora, M.; Świeca, M.; Franczyk, M.; Jakubczyk, A.; Bochnak, J.; Złotek, U. Biochemical Properties of Polyphenol Oxidases from Ready-to-Eat Lentil (Lens culinaris Medik.) Sprouts and Factors Affecting Their Activities: A Search for Potent Tools Limiting Enzymatic Browning. Foods 2019, 8, 154. [CrossRef] [PubMed]

151. Dalal, N.; Siddiqui, S. Evaluation of effects of chemical treatments on sensory attributes of sunflower microgreens with storage. J. Pharmacogn. Phytochem. 2020, 9, 439-443.

152. Vale, A.P.; Santos, J.; Brito, N.V.; Marinho, C.; Amorim, V.; Rosa, E.; Oliveira, M.B.P.P.P. Effect of refrigerated storage on the bioactive compounds and microbial quality of Brassica oleraceae sprouts. Postharvest Biol. Technol. 2015, 109, 120-129. [CrossRef]

153. Keshri, J.; Krouptiski, Y.; Abu-Fani, L.; Achmon, Y.; Bauer, T.S.; Zarka, O.; Maler, I.; Pinto, R.; Sela Saldinger, S. Dynamics of bacterial communities in alfalfa and mung bean sprouts during refrigerated conditions. Food Microbiol. 2019, 84, 103261. [CrossRef]

154. Ishikawa, D.; Shigihara, I.; Nakai, R.; Tamate, H.; Tsukada, Y.; Fujii, T. High Pressure Induced Effects on Free Amino Acid Generation in Mung Bean Sprouts during Preservation after Trigger Pressurization. Food Sci. Technol. Res. 2019, 25, 49-55. [CrossRef]

155. Westphal, A.; Riedl, K.M.; Cooperstone, J.L.; Kamat, S.; Balasubramaniam, V.M.; Schwartz, S.J.; Böhm, V. High-Pressure Processing of Broccoli Sprouts: Influence on Bioactivation of Glucosinolates to Isothiocyanates. J. Agric. Food Chem. 2017, 65, 8578-8585. [CrossRef]

156. Xiao, Z.; Luo, Y.; Lester, G.E.; Kou, L.; Yang, T.; Wang, Q. Postharvest quality and shelf life of radish microgreens as impacted by storage temperature, packaging film, and chlorine wash treatment. LWT Food Sci. Technol. 2014, 55, 551-558. [CrossRef]

157. D'ambrosio, T.; Amodio, M.L.; Pastore, D.; De Santis, G.; Colelli, G. Chemical, physical and sensorial characterization of fresh quinoa sprouts (Chenopodium quinoa Willd.) and effects of modified atmosphere packaging on quality during cold storage. Food Packag. Shelf Life 2017, 14, 52-58. [CrossRef]

158. Wilson, M.D.; Stanley, R.A.; Eyles, A.; Ross, T. Innovative processes and technologies for modified atmosphere packaging of fresh and fresh-cut fruits and vegetables. Crit. Rev. Food Sci. Nutr. 2019, 59, 411-422. [CrossRef] 
159. Bello, C.; Maldini, M.; Baima, S.; Scaccini, C.; Natella, F. Glucoraphanin and sulforaphane evolution during juice preparation from broccoli sprouts. Food Chem. 2018, 268, 249-256. [CrossRef] [PubMed]

160. Simsek, S.; El, S.N.; Kancabas Kilinc, A.; Karakaya, S. Vegetable and fermented vegetable juices containing germinated seeds and sprouts of lentil and cowpea. Food Chem. 2014, 156, 289-295. [CrossRef]

161. Wu, F.; Xu, X. Sprouted Grains-Based Fermented Products; Elsevier Inc.: Amsterdam, The Netherlands, 2018; ISBN 9780128115251.

162. Mridula, D.; Sharma, M. Development of non-dairy probiotic drink utilizing sprouted cereals, legume and soymilk. LWT Food Sci. Technol. 2015, 62, 482-487. [CrossRef]

163. Xiao-mei, L.I. Preparation of Germinated Soybean Yogurt. Food Sci. 2011, 2. [CrossRef]

164. Aminah, S.; Meikawati, W.; Rosidi, A. Nutrition retention of product based on soybean sprouts flour and corn sprout flour enriched with duck eggshell. IOP Conf. Ser. Earth Environ. Sci. 2019, 292, 012009. [CrossRef]

165. Klopsch, R.; Baldermann, S.; Hanschen, F.S.; Voss, A.; Rohn, S.; Schreiner, M.; Neugart, S. Brassica-enriched wheat bread: Unraveling the impact of ontogeny and breadmaking on bioactive secondary plant metabolites of pak choi and kale. Food Chem. 2019, 295, 412-422. [CrossRef] [PubMed]

166. Falcinelli, B.; Calzuola, I.; Gigliarelli, L.; Torricelli, R.; Polegri, L.; Vizioli, V.; Benincasa, P.; Marsili, V. Phenolic content and antioxidant activity of wholegrain breads from modern and old wheat (Triticum aestivum L.) cultivars and ancestors enriched with wheat sprout powder. Ital. J. Agron. 2018, 13, 297-302. [CrossRef]

167. Hernandez-Aguilar, C.; Dominguez-Pacheco, A.; Palma Tenango, M.; Valderrama-Bravo, C.; Soto Hernández, M.; Cruz-Orea, A.; Ordonez-Miranda, J. Lentil sprouts: A nutraceutical alternative for the elaboration of bread. J. Food Sci. Technol. 2020, 57, 1817-1829. [CrossRef]

168. Hidalgo, A.; Tumbas Šaponjac, V.; Ćetković, G.; Šeregelj, V.; Čanadanović-Brunet, J.; Chiosa, D.; Brandolini, A. Antioxidant properties and heat damage of water biscuits enriched with sprouted wheat and barley. LWT 2019, 114, 114. [CrossRef]

169. Islam, M.Z.; Yu, D.S.; Lee, Y.T. The Effect of Heat Processing on Chemical Composition and Antioxidative Activity of Tea Made from Barley Sprouts and Wheat Sprouts. J. Food Sci. 2019, 84, 1340-1345. [CrossRef] [PubMed]

170. Šaponjac, V.T.; Ćetković, G.; Čanadanović-Brunet, J.; Mandić, A.; Šeregelj, V.; Vulić, J.; Stajčić, S. Bioactive Characteristics and Storage of Salt Mixtures Seasoned with Powdered Cereal Sprouts. J. Chem. 2019, 2019, 1-9. [CrossRef]

171. Gubanenko, G.A.; Naimushina, L.V.; Zhukova, K.O.; Rechkina, A.; Mayurnikova, L.A.; Kiseleva, O.V. Rational use of wheat processing products to create a composite flour mixture. IOP Conf. Ser. Earth Environ. Sci. 2020, 421. [CrossRef]

172. Dziki, D.; Habza-Kowalska, E.; Gawlik-Dziki, U.; Miś, A.; Rózyło, R.; Krzysiak, Z.; Hassoon, W.H. Drying kinetics, grinding characteristics, and physicochemical properties of broccoli sprouts. Processes 2020, 8, 97. [CrossRef]

173. Mattioli, S.; Dal Bosco, A.; Castellini, C.; Falcinelli, B.; Sileoni, V.; Marconi, O.; Mancinelli, A.C.; Cotozzolo, E.; Benincasa, P. Effect of heat- and freeze-drying treatments on phytochemical content and fatty acid profile of alfalfa and flax sprouts. J. Sci. Food Agric. 2019, 99, 4029-4035. [CrossRef]

174. Gan, R.Y.; Lui, W.Y.; Chan, C.L.; Corke, H. Hot Air Drying Induces Browning and Enhances Phenolic Content and Antioxidant Capacity in Mung Bean (Vigna radiata L.) Sprouts. J. Food Process. Preserv. 2017, 41, 2-9. [CrossRef]

175. Złotek, U.; Gawlik-Dziki, U.; Dziki, D.; Awieca, M.; Nowak, R.; Martinez, E. Influence of Drying Temperature on Phenolic Acids Composition and Antioxidant Activity of Sprouts and Leaves of White and Red Quinoa. J. Chem. 2019, 2019, 1-8. [CrossRef]

176. Klopsch, R.; Baldermann, S.; Voss, A.; Rohn, S.; Schreiner, M.; Neugart, S. Bread enriched with legume microgreens and leaves-ontogenetic and baking-driven changes in the profile of secondary plant metabolites. Front. Chem. 2018, 6, 1-19. [CrossRef]

177. Peng, J.; Tang, J.; Barrett, D.M.; Sablani, S.S.; Anderson, N.; Powers, J.R. Thermal pasteurization of ready-to-eat foods and vegetables: Critical factors for process design and effects on quality. Crit. Rev. Food Sci. Nutr. 2017, 57, 2970-2995. [CrossRef]

178. Bevilacqua, A.; Petruzzi, L.; Perricone, M.; Speranza, B.; Campaniello, D.; Sinigaglia, M.; Corbo, M.R. Nonthermal Technologies for Fruit and Vegetable Juices and Beverages: Overview and Advances. Compr. Rev. Food Sci. Food Saf. 2018, 17, 2-62. [CrossRef] 
179. Roobab, U.; Aadil, R.M.; Madni, G.M.; Bekhit, A.E.-D. The Impact of Nonthermal Technologies on the Microbiological Quality of Juices: A Review. Compr. Rev. Food Sci. Food Saf. 2018, 17, 437-457. [CrossRef]

180. Ali, N.; Popović, V.; Koutchma, T.; Warriner, K.; Zhu, Y. Effect of thermal, high hydrostatic pressure, and ultraviolet-C processing on the microbial inactivation, vitamins, chlorophyll, antioxidants, enzyme activity, and color of wheatgrass juice. J. Food Process Eng. 2020, 43, 1-11. [CrossRef]

181. Knödler, M.; Berger, M.; Dobrindt, U. Long-term survival of the Shiga toxin-producing Escherichia coli O104:H4 outbreak strain on fenugreek seeds. Food Microbiol. 2016, 59, 190-195. [CrossRef]

182. Landry, K.S.; Komaiko, J.; Wong, D.E.; Xu, T.; Mcclements, D.J.; Mclandsborough, L. Inactivation of Salmonella on Sprouting Seeds Using a Spontaneous Carvacrol Nanoemulsion Acidified with Organic Acids. J. Food Prot. 2016, 79, 1115-1126. [CrossRef]

183. Iacumin, L.; Comi, G. Microbial quality of raw and ready-to-eat mung bean sprouts produced in Italy. Food Microbiol. 2019, 82, 371-377. [CrossRef]

184. Adhikari, A.; Chhetri, V.S.; Bhattacharya, D.; Cason, C.; Luu, P.; Suazo, A. Effectiveness of daily rinsing of alfalfa sprouts with aqueous chlorine dioxide and ozonated water on the growth of Listeria monocytogenes during sprouting. Lett. Appl. Microbiol. 2019, 69, 252-257. [CrossRef]

185. Žudytè, B.; Lukšienè, Ž. Toward better microbial safety of wheat sprouts: Chlorophyllin-based photosensitization of seeds. Photochem. Photobiol. Sci. 2019, 18, 2521-2530. [CrossRef]

186. Hylton, R.K.; Sanchez-Maldonado, A.F.; Peyvandi, P.; Rahmany, F.; Dagher, F.; Leon-velarde, C.G.; Warriner, K.; Hamidi, A.M. Decontamination of Chia and Flax Seed Inoculated with Salmonella and Surrogate, Enterococcus faecium NRRL B-2354, Using a Peracetic Acid Sanitizing Solution: Antimicrobial Efficacy and Impact on Seed Functionality. J. Food Prot. 2019, 82, 486-493. [CrossRef]

187. Sabillón, L.; Stratton, J.; Rose, D.; Bianchini, A. Reduction in pathogenic load of wheat by tempering with saline organic acid solutions at different seasonal temperatures. Int. J. Food Microbiol. 2020, 313, 108381. [CrossRef]

188. Zhang, C.; Xia, X.; Li, B.; Hung, Y.-C. Disinfection efficacy of electrolyzed oxidizing water on brown rice soaking and germination. Food Control 2018, 89, 38-45. [CrossRef]

189. Liang, D.; Wang, Q.; Zhao, D.; Han, X.; Hao, J. Systematic application of slightly acidic electrolyzed water (SAEW) for natural microbial reduction of buckwheat sprouts. LWT 2019, 108, 14-20. [CrossRef]

190. Zhang, C.; Zhang, Y.; Zhao, Z.; Liu, W.; Chen, Y.; Yang, G.; Xia, X.; Cao, Y. The application of slightly acidic electrolyzed water in pea sprout production to ensure food safety, biological and nutritional quality of the sprout. Food Control 2019, 104, 83-90. [CrossRef]

191. Zhang, C.; Zhao, Z.; Yang, G.; Shi, Y.; Zhang, Y.; Shi, C.; Xia, X. Effect of slightly acidic electrolyzed water on natural Enterobacteriaceae reduction and seed germination in the production of alfalfa sprouts. Food Microbiol. 2020, 103414. [CrossRef]

192. Jribi, S.; Molnàr, H.; Antal, O.T.; Adànyi, N.; Kheriji, O.; Naàr, Z.; Debbabi, H. Zinc fortification as a tool for improving sprout hygienic and nutritional quality: A factorial design approach. J. Sci. Food Agric. 2019, 99, 5187-5194. [CrossRef]

193. Butscher, D.; Van Loon, H.; Waskow, A.; Rudolf von Rohr, P.; Schuppler, M. Plasma inactivation of microorganisms on sprout seeds in a dielectric barrier discharge. Int. J. Food Microbiol. 2016, 238, 222-232. [CrossRef]

194. Fan, X.; Sokorai, K.; Weidauer, A.; Gotzmann, G.; Rögner, F.-H.; Koch, E. Comparison of gamma and electron beam irradiation in reducing populations of E. coli artificially inoculated on mung bean, clover and fenugreek seeds, and affecting germination and growth of seeds. Radiat. Phys. Chem. 2017, 130, 306-315. [CrossRef]

195. Choi, S.; Beuchat, L.R.; Kim, H.; Ryu, J.-H. Viability of sprout seeds as affected by treatment with aqueous chlorine dioxide and dry heat, and reduction of Escherichia coli O157:H7 and Salmonella enterica on pak choi seeds by sequential treatment with chlorine dioxide, drying, and dry heat. Food Microbiol. 2016, 54, 127-132. [CrossRef]

196. Waskow, A.; Betschart, J.; Butscher, D.; Oberbossel, G.; Klöti, D.; Büttner-Mainik, A.; Adamcik, J.; von Rohr, P.R.; Schuppler, M. Characterization of Efficiency and Mechanisms of Cold Atmospheric Pressure Plasma Decontamination of Seeds for Sprout Production. Front. Microbiol. 2018, 9, 3164. [CrossRef] 
197. Reyes-Jurado, F.; Navarro-Cruz, A.R.; Méndez-Aguilar, J.; Ochoa-Velasco, C.E.; Mani-López, E.; Jiménez-Munguía, M.T.; Palou, E.; López-Malo, A.; Ávila-Sosa, R. High-Intensity Light Pulses To Inactivate Salmonella Typhimurium on Mexican Chia (Salvia hispanica L.) Seeds. J. Food Prot. 2019, 82, 1272-1277. [CrossRef]

198. Kim, S.-M.; Hwang, H.-J.; Cheigh, C.-I.; Chung, M.-S. Bactericidal effect of intense pulsed light on seeds without loss of viability. Food Sci. Biotechnol. 2019, 28, 281-287. [CrossRef]

199. Puligundla, P.; Kim, J.-W.; Mok, C. Effects of Nonthermal Plasma Treatment on Decontamination and Sprouting of Radish (Raphanus sativus L.) Seeds. Food Bioprocess Technol. 2017, 10, 1093-1102. [CrossRef]

200. Puligundla, P.; Kim, J.-W.; Mok, C. Effect of corona discharge plasma jet treatment on decontamination and sprouting of rapeseed (Brassica napus L.) seeds. Food Control 2017, 71, 376-382. [CrossRef]

201. Kim, J.-W.; Puligundla, P.; Mok, C. Effect of corona discharge plasma jet on surface-borne microorganisms and sprouting of broccoli seeds. J. Sci. Food Agric. 2017, 97, 128-134. [CrossRef] [PubMed]

202. Puligundla, P.; Kim, J.-W.; Mok, C. Effect of atmospheric pressure plasma treatment on seed decontamination and sprouting of pak choi (Brassica rapa L. subsp. chinensis (L.) Hanelt). Chiang Mai J. Sci. 2018, 45, 2679-2690.

203. Zhou, R.; Li, J.; Zhou, R.; Zhang, X.; Yang, S. Atmospheric-pressure plasma treated water for seed germination and seedling growth of mung bean and its sterilization effect on mung bean sprouts. Innov. Food Sci. Emerg. Technol. 2019, 53, 36-44. [CrossRef]

204. Sarooei, S.J.; Abbasi, A.; Shaghaghian, S.; Berizi, E. Effect of Ozone as a Disinfectant on Microbial Load and Chemical Quality of Raw Wheat Germ. Ozone Sci. Eng. 2019, 41, 562-570. [CrossRef]

205. Mohammad, Z.; Kalbasi-Ashtari, A.; Riskowski, G.; Castillo, A. Reduction of Salmonella and Shiga toxin-producing Escherichia coli on alfalfa seeds and sprouts using an ozone generating system. Int. J. Food Microbiol. 2019, 289, 57-63. [CrossRef]

206. Kang, J.-W.; Lee, J.-I.; Jeong, S.-Y.; Kim, Y.-M.; Kang, D.-H. Effect of 222-nm krypton-chloride excilamp treatment on inactivation of Escherichia coli O157:H7 and Salmonella Typhimurium on alfalfa seeds and seed germination. Food Microbiol. 2019, 82, 171-176. [CrossRef]

207. Hong, E.-J.; Kang, D.-H. Effect of sequential dry heat and hydrogen peroxide treatment on inactivation of Salmonella Typhimurium on alfalfa seeds and seeds germination. Food Microbiol. 2016, 53, 9-14. [CrossRef]

208. Trzaskowska, M.; Dai, Y.; Delaquis, P.; Wang, S. Pathogen reduction on mung bean reduction of Escherichia coli O157:H7, Salmonella enterica and Listeria monocytogenes on mung bean using combined thermal and chemical treatments with acetic acid and hydrogen peroxide. Food Microbiol. 2018, 76, 62-68. [CrossRef]

209. Wang, S.; Chen, J.; Wakeling, C.; Bach, S.; Orban, S.; Delaquis, P. Disinfection of Alfalfa and Radish Sprouting Seed Using Oxidizing Agents and Treatments Compliant with Organic Food Production Principles. J. Food Prot. 2019, 83, 779-787. [CrossRef]

210. Goñi, M.G.; Tomadoni, B.M.; Audisio, M.C.; Ibarguren, C.; Roura, S.I.; del Moreira, M.R.; Ponce, A.G. Application of bacteriocins from Enterococcus hirae on butterhead lettuce seeds inoculated with Escherichia coli O157: H7. Int. Food Res. J. 2016, 23, 2653-2660.

211. Fong, K.; LaBossiere, B.; Switt, A.I.M.; Delaquis, P.; Goodridge, L.; Levesque, R.C.; Danyluk, M.D.; Wang, S. Characterization of Four Novel Bacteriophages Isolated from British Columbia for Control of Non-typhoidal Salmonella in Vitro and on Sprouting Alfalfa Seeds. Front. Microbiol. 2017, 8, 2193. [CrossRef]

212. Lone, A.; Anany, H.; Hakeem, M.; Aguis, L.; Avdjian, A.-C.; Bouget, M.; Atashi, A.; Brovko, L.; Rochefort, D.; Griffiths, M.W. Development of prototypes of bioactive packaging materials based on immobilized bacteriophages for control of growth of bacterial pathogens in foods. Int. J. Food Microbiol. 2016, 217, 49-58. [CrossRef] [PubMed]

213. Kim, W.-I.; Choi, S.Y.; Han, I.; Cho, S.K.; Lee, Y.; Kim, S.; Kang, B.; Choi, O.; Kim, J. Inhibition of Salmonella enterica growth by competitive exclusion during early alfalfa sprout development using a seed-dwelling Erwinia persicina strain EUS78. Int. J. Food Microbiol. 2020, 312, 108374. [CrossRef] [PubMed]

214. Rossi, F.; Lathrop, A. Effects of Lactobacillus plantarum, Pediococcus acidilactici, and Pediococcus pentosaceus on the Growth of Listeria monocytogenes and Salmonella on Alfalfa Sprouts. J. Food Prot. 2019, 82, 522-527. [CrossRef] [PubMed]

215. Yin, H.-B.; Boomer, A.; Chen, C.-H.; Patel, J. Efficacy of benzyl isothiocyanate for controlling Salmonella on alfalfa seeds and sprouts. Int. J. Food Sci. Technol. 2020, 55, 2669-2676. [CrossRef] 
216. Choi, J.-S. Seed-surface disinfection and germination effects of grapefruit seed extract (GSE) on Lactuca sativa seeds. Toxicol. Environ. Health Sci. 2017, 9, 169-175. [CrossRef]

217. Lorenzo-Leal, A.C.; Palou, E.; López-Malo, A. Evaluation of the efficiency of allspice, thyme and rosemary essential oils on two foodborne pathogens in in-vitro and on alfalfa seeds, and their effect on sensory characteristics of the sprouts. Int. J. Food Microbiol. 2019, 295, 19-24. [CrossRef]

218. Sahan, N.; Tornuk, F. Application of plant hydrosols for decontamination of wheat, lentil and mung bean seeds prior to sprouting. Qual. Assur. Saf. Crop. Foods 2016, 8, 575-582. [CrossRef]

219. Gan, R.-Y.; Lui, W.-Y.; Wu, K.; Chan, C.-L.; Dai, S.-H.; Sui, Z.-Q.; Corke, H. Bioactive compounds and bioactivities of germinated edible seeds and sprouts: An updated review. Trends Food Sci. Technol. 2017, 59, 1-14. [CrossRef]

220. Williamson, E.M.; Liu, X.; Izzo, A.A. Trends in use, pharmacology, and clinical applications of emerging herbal nutraceuticals. Br. J. Pharmacol. 2020, 177, 1227-1240. [CrossRef] [PubMed]

221. Brower, V. Nutraceuticals: Poised for a healthy slice of the healthcare market? Nat. Biotechnol. 1998, 16, 728-731. [CrossRef] [PubMed]

222. Tang, D.; Dong, Y.; Ren, H.; Li, L.; He, C. A review of phytochemistry, metabolite changes, and medicinal uses of the common food mung bean and its sprouts (Vigna radiata). Chem. Cent. J. 2014, 8, 4. [CrossRef] [PubMed]

223. Gao, J.; Yu, X.; Ma, F.; Li, J. RNA-Seq Analysis of Transcriptome and Glucosinolate Metabolism in Seeds and Sprouts of Broccoli (Brassica oleracea var. italic). PLoS ONE 2014, 9, e88804. [CrossRef] [PubMed]

224. Shlisky, J.; Bloom, D.E.; Beaudreault, A.R.; Tucker, K.L.; Keller, H.H.; Freund-Levi, Y.; Fielding, R.A.; Cheng, F.W.; Jensen, G.L.; Wu, D.; et al. Nutritional Considerations for Healthy Aging and Reduction in Age-Related Chronic Disease. Adv. Nutr. 2017, 8, 17-26. [CrossRef]

225. Schäfer, F.; Jeanne, J.-F. Evaluating the effects of food on health in a world of evolving operational challenges. Contemp. Clin. Trials Commun. 2018, 12, 51-54. [CrossRef]

226. Kroeger, C.M.; Garza, C.; Lynch, C.J.; Myers, E.; Rowe, S.; Schneeman, B.O.; Sharma, A.M.; Allison, D.B. Scientific rigor and credibility in the nutrition research landscape. Am. J. Clin. Nutr. 2018, 107, 484-494. [CrossRef]

227. Ferruzza, S.; Natella, F.; Ranaldi, G.; Murgia, C.; Rossi, C.; Trošt, K.; Mattivi, F.; Nardini, M.; Maldini, M.; Giusti, A.M.; et al. Nutraceutical Improvement Increases the Protective Activity of Broccoli Sprout Juice in a Human Intestinal Cell Model of Gut Inflammation. Pharmaceuticals 2016, 9, 48. [CrossRef]

228. Risbridger, G.P. Human Cell Lines as Tools of Our Trade: "Laying It on the (Cell) Line". Mol. Endocrinol. 2015, 29, 1-2. [CrossRef]

229. Liu, Y.; Mi, Y.; Mueller, T.; Kreibich, S.; Williams, E.G.; Van Drogen, A.; Borel, C.; Frank, M.; Germain, P.-L.; Bludau, I.; et al. Multi-omic measurements of heterogeneity in HeLa cells across laboratories. Nat. Biotechnol. 2019, 37, 314-322. [CrossRef]

230. Min, M.; Spencer, S.L. Spontaneously slow-cycling subpopulations of human cells originate from activation of stress-response pathways. PLoS Biol. 2019, 17, 1-25. [CrossRef]

231. Lee, J.K.; Bloom, J.; Zubeldia-Plazaola, A.; Garbe, J.C.; Stampfer, M.R.; LaBarge, M.A. Different culture media modulate growth, heterogeneity, and senescence in human mammary epithelial cell cultures. PLoS ONE 2018, 13, e0204645. [CrossRef]

232. Bedard, P.L.; Hansen, A.R.; Ratain, M.J.; Siu, L.L. Tumour heterogeneity in the clinic. Nature 2013, 501, 355-364. [CrossRef]

233. Cencic, A.; Chingwaru, W. The Role of Functional Foods, Nutraceuticals, and Food Supplements in Intestinal Health. Nutrients 2010, 2, 611-625. [CrossRef]

234. Narmada, B.C.; Goh, Y.T.; Li, H.; Sinha, S.; Yu, H.; Cheung, C. Human Stem Cell-Derived Endothelial-Hepatic Platform for Efficacy Testing of Vascular-Protective Metabolites from Nutraceuticals. Stem Cells Transl. Med. 2017, 6, 851-863. [CrossRef]

235. Booij, T.H.; Price, L.S.; Danen, E.H.J. 3D Cell-Based Assays for Drug Screens: Challenges in Imaging, Image Analysis, and High-Content Analysis. SLAS Discov. Adv. Sci. Drug Discov. 2019, 24, 615-627. [CrossRef]

236. Phan, N.; Hong, J.J.; Tofig, B.; Mapua, M.; Elashoff, D.; Moatamed, N.A.; Huang, J.; Memarzadeh, S.; Damoiseaux, R.; Soragni, A. A simple high-throughput approach identifies actionable drug sensitivities in patient-derived tumor organoids. Commun. Biol. 2019, 2, 78. [CrossRef] 
237. Ganesan, K.; Xu, B. A critical review on phytochemical profile and health promoting effects of mung bean (Vigna radiata). Food Sci. Hum. Wellness 2018, 7, 11-33. [CrossRef]

238. Lemmens, E.; Moroni, A.V.; Pagand, J.; Heirbaut, P.; Ritala, A.; Karlen, Y.; Lê, K.-A.; den Broeck, H.C.; Brouns, F.J.P.H.; De Brier, N.; et al. Impact of Cereal Seed Sprouting on Its Nutritional and Technological Properties: A Critical Review. Compr. Rev. Food Sci. Food Saf. 2019, 18, 305-328. [CrossRef]

239. Santini, A.; Cammarata, S.M.; Capone, G.; Ianaro, A.; Tenore, G.C.; Pani, L.; Novellino, E. Nutraceuticals: Opening the debate for a regulatory framework. Br. J. Clin. Pharmacol. 2018, 84, 659-672. [CrossRef] [PubMed]

240. Hasler, C.M. Functional Foods: Benefits, Concerns and Challenges-A Position Paper from the American Council on Science and Health. J. Nutr. 2002, 132, 3772-3781. [CrossRef] [PubMed]

241. Yagishita, Y.; Fahey, J.W.; Dinkova-Kostova, A.T.; Kensler, T.W. Broccoli or Sulforaphane: Is It the Source or Dose That Matters? Molecules 2019, 24, 3593. [CrossRef] [PubMed]

242. Quirante-Moya, S.; García-Ibañez, P.; Quirante-Moya, F.; Villaño, D.; Moreno, D.A. The Role of Brassica Bioactives on Human Health: Are We Studying It the Right Way? Molecules 2020, 25, 1591. [CrossRef]

243. Rein, M.J.; Renouf, M.; Cruz-Hernandez, C.; Actis-Goretta, L.; Thakkar, S.K.; da Silva Pinto, M. Bioavailability of bioactive food compounds: A challenging journey to bioefficacy. Br. J. Clin. Pharmacol. 2013, 75, 588-602. [CrossRef] [PubMed]

244. Sudini, K.; Diette, G.B.; Breysse, P.N.; McCormack, M.C.; Bull, D.; Biswal, S.; Zhai, S.; Brereton, N.; Peng, R.D.; Matsui, E.C. A Randomized Controlled Trial of the Effect of Broccoli Sprouts on Antioxidant Gene Expression and Airway Inflammation in Asthmatics. J. Allergy Clin. Immunol. Pract. 2016, 4, 932-940. [CrossRef] [PubMed]

245. Duran, C.G.; Burbank, A.J.; Mills, K.H.; Duckworth, H.R.; Aleman, M.M.; Kesic, M.J.; Peden, D.B.; Pan, Y.; Zhou, H.; Hernandez, M.L. A proof-of-concept clinical study examining the NRF2 activator sulforaphane against neutrophilic airway inflammation. Respir. Res. 2016, 17, 89. [CrossRef] [PubMed]

246. Brown, R.H.; Reynolds, C.; Brooker, A.; Talalay, P.; Fahey, J.W. Sulforaphane improves the bronchoprotective response in asthmatics through Nrf2-mediated gene pathways. Respir. Res. 2015, 16, 106. [CrossRef]

247. Morand, C.; De Roos, B.; Garcia-Conesa, M.T.; Gibney, E.R.; Landberg, R.; Manach, C.; Milenkovic, D.; Rodriguez-Mateos, A.; Van de Wiele, T.; Tomas-Barberan, F. Why interindividual variation in response to consumption of plant food bioactives matters for future personalised nutrition. Proc. Nutr. Soc. 2020, 79, 225-235. [CrossRef]

248. Son, T.G.; Camandola, S.; Mattson, M.P. Hormetic Dietary Phytochemicals. NeuroMolecular Med. 2008, 10, 236. [CrossRef]

249. Landberg, R.; Manach, C.; Kerckhof, F.-M.; Minihane, A.-M.; Saleh, R.N.M.; De Roos, B.; Tomas-Barberan, F.; Morand, C.; Van de Wiele, T. Future prospects for dissectinginter-individual variability in the absorption, distribution and elimination of plantbioactives of relevance for cardiometabolic endpoints. Eur. J. Nutr. 2019, 58, 21-36. [CrossRef]

250. Shahidi, F. Beneficial Health Effects and Drawbacks of Antinutrients and Phytochemicals in Foods. In Antinutrients and Phytochemicals in Food; ACS Symposium Series; American Chemical Society: Washington, DC, USA, 1997; Volume 662, p. 1. ISBN 9780841234987.

251. Peluso, I. Dietary Antioxidants: Micronutrients and Antinutrients in Physiology and Pathology. Antioxidants 2019, 8, 642. [CrossRef] [PubMed]

252. Kumari, M.; Jain, S. Tannins: An antinutrient with positive effect to manage diabetes. Res. J. Recent Sci. ISSN 2012, 2277, 2502.

253. Nissar, J.; Ahad, T.; Naik, H.R.; Hussain, S.Z. A review phytic acid: As antinutrient or nutraceutical. J. Pharmacogn. Phytochem. 2017, 6, 1554-1560.

254. Calder, P.C. Comment on Christiansen et al.: When food met pharma. Br. J. Nutr. 2015, 114, 1109-1110. [CrossRef] [PubMed]

255. Akande, K.E.; Doma, U.D.; Agu, H.O.; Adamu, H.M. Major antinutrients found in plant protein sources: Their effect on nutrition. Pakistan J. Nutr. 2010, 9, 827-832. [CrossRef]

256. Ghavidel, R.A.; Prakash, J. The impact of germination and dehulling on nutrients, antinutrients, in vitro iron and calcium bioavailability and in vitro starch and protein digestibility of some legume seeds. LWT Food Sci. Technol. 2007, 40, 1292-1299. [CrossRef] 
257. Preet, K.; Punia, D. Antinutrients and Digestibility (in vitro) of Soaked, Dehulled and Germinated Cowpeas. Nutr. Health 2000, 14, 109-117. [CrossRef]

258. Mishra, M.; Jain, S. Effect of Soaking and Germination on Nutritional profile and Antinutrients of Buckwheat Whole (Fagopyrum esculentum). Int. J. Curr. Microbiol. App. Sci. 2019, 8, 3384-3393. [CrossRef]

259. Padmashree, N.N.; Handu, S.; Khan, M.A.; Semwal, A.D.; Sharma, G.K. Effect of Germination on Nutritional, Antinutritional and Rheological Characteristics of Chenopodium quinoa. Energy 2019, 375, 353.02b. [CrossRef]

260. Mbithi-Mwikya, S.; Van Camp, J.; Yiru, Y.; Huyghebaert, A. Nutrient and Antinutrient Changes in Finger Millet (Eleusine coracan) During Sprouting. LWT Food Sci. Technol. 2000, 33, 9-14. [CrossRef]

261. Budhwar, S.; Sethi, K.; Chakraborty, M. Efficacy of germination and probiotic fermentation on underutilized cereal and millet grains. Food Prod. Process. Nutr. 2020, 2, 12. [CrossRef]

262. Bouajila, A.; Ammar, H.; Chahine, M.; Khouja, M.; Hamdi, Z.; Khechini, J.; Salem, A.-F.Z.M.; Ghorbel, A.; López, S. Changes in phytase activity, phosphorus and phytate contents during grain germination of barley (Hordeum vulgare L.) cultivars. Agrofor. Syst. 2019, 94, 1151-1159. [CrossRef]

263. Kajla, P.; Sharma, A.; Sood, D.R. Effect of germination on proximate principles, minerals and anti nutrients of flaxseeds. Asian J. Dairy Food Res. 2017, 36, 52-57. [CrossRef]

264. Pal, R.S.; Bhartiya, A.; Yadav, P.; Kant, L.; Mishra, K.K.; Aditya, J.P.; Pattanayak, A. Effect of dehulling, germination and cooking on nutrients, anti-nutrients, fatty acid composition and antioxidant properties in lentil (Lens culinaris). J. Food Sci. Technol. 2017, 54, 909-920. [CrossRef] [PubMed]

265. Cardador-Martínez, A.; Martínez-Tequitlalpan, Y.; Gallardo-Velazquez, T.; Sánchez-Chino, X.M.; Martínez-Herrera, J.; Corzo-Ríos, L.J.; Jiménez-Martínez, C. Effect of Instant Controlled Pressure-Drop on the Non-Nutritional Compounds of Seeds and Sprouts of Common Black Bean (Phaseolus vulgaris L.). Molecules 2020, 25, 1464. [CrossRef] [PubMed]

266. Khattak, A.B.; Zeb, A.; Bibi, N.; Khalil, S.A.; Khattak, M.S. Influence of germination techniques on phytic acid and polyphenols content of chickpea (Cicer arietinum L.) sprouts. Food Chem. 2007, 104, 1074-1079. [CrossRef]

267. Li, Y.; Sun, X.; Ma, Z.; Cui, Y.; Du, C.; Xia, X.; Qian, H. Beneficial Influence of Short-Term Germination on Decreasing Allergenicity of Peanut Proteins. J. Food Sci. 2016, 81, T255-T261. [CrossRef]

268. Rao, H.; Chen, C.; Tian, Y.; Li, Y.; Gao, Y.; Tao, S.; Xue, W. Germination results in reduced allergenicity of peanut by degradation of allergens and resveratrol enrichment. Innov. Food Sci. Emerg. Technol. 2018, 50, 188-195. [CrossRef]

269. Wolejszo, A.; Szymkiewicz, A.; Troszynska, A. Immunoreactive properties and sensory quality of lentil [Lens culinaris] and mung bean [Vigma radiata L.] sprouts. Polish J. Food Nutr. Sci. 2007, 57, 415-420.

270. Peñas, E.; Gomez, R.; Frias, J.; Baeza, M.L.; Vidal-Valverde, C. High hydrostatic pressure effects on immunoreactivity and nutritional quality of soybean products. Food Chem. 2011, 125, 423-429. [CrossRef]

271. Guhsl, E.E.; Hofstetter, G.; Hemmer, W.; Ebner, C.; Vieths, S.; Vogel, L.; Breiteneder, H.; Radauer, C. Vig r 6, the cytokinin-specific binding protein from mung bean (Vigna radiata) sprouts, cross-reacts with Bet $\mathrm{V}$ 1-related allergens and binds IgE from birch pollen allergic patients' sera. Mol. Nutr. Food Res. 2014, 58, 625-634. [CrossRef] [PubMed]

272. Jensen, L.B.; Pedersen, M.H.; Skov, P.S.; Poulsen, L.K.; Bindslev-Jensen, C.; Andersen, S.B.; Torp, A.M. Peanut cross-reacting allergens in seeds and sprouts of a range of legumes. Clin. Exp. Allergy 2008, 38, 1969-1977. [CrossRef] [PubMed]

273. FDA-Food and Drug Administration Compliance with and Implementation of the Standards for the Growing, Harvesting, Packing, and Holding of Produce for Human Consumption for Sprouts Operations: Guidance for Industry; 2017. Available online: https://www.fda.gov/media/102430/download (accessed on 27 August 2020).

274. Cragg, G.M.; Katz, F.; Newman, D.J.; Rosenthal, J. The impact of the United Nations Convention on Biological Diversity on natural products research. Nat. Prod. Rep. 2012, 29, 1407-1423. [CrossRef] [PubMed]

275. Li, J.W.-H.; Vederas, J.C. Drug Discovery and Natural Products: End of an Era or an Endless Frontier? Science 2009, 325, 161-165. [CrossRef] [PubMed]

276. Neugart, S.; Baldermann, S.; Hanschen, F.S.; Klopsch, R.; Wiesner-Reinhold, M.; Schreiner, M. The intrinsic quality of brassicaceous vegetables: How secondary plant metabolites are affected by genetic, environmental, and agronomic factors. Sci. Hortic. 2018, 233, 460-478. [CrossRef] 
277. Guo, R.; Huang, Z.; Deng, Y.; Chen, X.; XuHan, X.; Lai, Z. Comparative Transcriptome Analyses Reveal a Special Glucosinolate Metabolism Mechanism in Brassica alboglabra Sprouts. Front. Plant Sci. 2016, 7, 1497. [CrossRef]

278. Wang, S.; Alseekh, S.; Fernie, A.R.; Luo, J. The Structure and Function of Major Plant Metabolite Modifications. Mol. Plant 2019, 12, 899-919. [CrossRef]

279. Koch, M.A.; Schuffenhauer, A.; Scheck, M.; Wetzel, S.; Casaulta, M.; Odermatt, A.; Ertl, P.; Waldmann, H. Charting biologically relevant chemical space: A structural classification of natural products (SCONP). Proc. Natl. Acad. Sci. USA 2005, 102, 17272-17277. [CrossRef]

280. Barker, A.; Kettle, J.G.; Nowak, T.; Pease, J.E. Expanding medicinal chemistry space. Drug Discov. Today 2013, 18, 298-304. [CrossRef]

281. Santos, R.; Ursu, O.; Gaulton, A.; Bento, A.P.; Donadi, R.S.; Bologa, C.G.; Karlsson, A.; Al-Lazikani, B.; Hersey, A.; Oprea, T.I.; et al. A comprehensive map of molecular drug targets. Nat. Rev. Drug Discov. 2017, 16, 19-34. [CrossRef]

282. Chen, Y.; Garcia de Lomana, M.; Friedrich, N.-O.; Kirchmair, J. Characterization of the Chemical Space of Known and Readily Obtainable Natural Products. J. Chem. Inf. Model. 2018, 58, 1518-1532. [CrossRef] [PubMed]

283. Karageorgis, G.; Foley, D.J.; Laraia, L.; Waldmann, H. Principle and design of pseudo-natural products. Nat. Chem. 2020, 12, 227-235. [CrossRef] [PubMed]

284. Bode, H.B.; Bethe, B.; Höfs, R.; Zeeck, A. Big Effects from Small Changes: Possible Ways to Explore Nature's Chemical Diversity. ChemBioChem 2002, 3, 619-627. [CrossRef]

285. Romano, S.; Jackson, S.A.; Patry, S.; Dobson, A.D.W. Extending the "One Strain Many Compounds" (OSMAC) Principle to Marine Microorganisms. Mar. Drugs 2018, 16, 244. [CrossRef]

286. Nützmann, H.-W.; Huang, A.; Osbourn, A. Plant metabolic clusters-from genetics to genomics. New Phytol. 2016, 211, 771-789. [CrossRef]

287. Kautsar, S.A.; Suarez Duran, H.G.; Blin, K.; Osbourn, A.; Medema, M.H. plantiSMASH: Automated identification, annotation and expression analysis of plant biosynthetic gene clusters. Nucleic Acids Res. 2017, 45, W55-W63. [CrossRef]

288. Töpfer, N.; Fuchs, L.-M.; Aharoni, A. The PhytoClust tool for metabolic gene clusters discovery in plant genomes. Nucleic Acids Res. 2017, 45, 7049-7063. [CrossRef]

289. Wisecaver, J.H.; Borowsky, A.T.; Tzin, V.; Jander, G.; Kliebenstein, D.J.; Rokas, A. A Global Coexpression Network Approach for Connecting Genes to Specialized Metabolic Pathways in Plants. Plant Cell 2017, 29 , 944-959. [CrossRef]

290. Schläpfer, P.; Zhang, P.; Wang, C.; Kim, T.; Banf, M.; Chae, L.; Dreher, K.; Chavali, A.K.; Nilo-Poyanco, R.; Bernard, T.; et al. Genome-Wide Prediction of Metabolic Enzymes, Pathways, and Gene Clusters in Plants. Plant Physiol. 2017, 173, 2041-2059. [CrossRef]

291. Moore, B.M.; Wang, P.; Fan, P.; Leong, B.; Schenck, C.A.; Lloyd, J.P.; Lehti-Shiu, M.D.; Last, R.L.; Pichersky, E.; Shiu, S.-H. Robust predictions of specialized metabolism genes through machine learning. Proc. Natl. Acad. Sci. USA 2019, 116, 2344-2353. [CrossRef]

292. Liu, Z.; Suarez Duran, H.G.; Harnvanichvech, Y.; Stephenson, M.J.; Schranz, M.E.; Nelson, D.; Medema, M.H.; Osbourn, A. Drivers of metabolic diversification: How dynamic genomic neighbourhoods generate new biosynthetic pathways in the Brassicaceae. New Phytol. 2020, 227, 1109-1123. [CrossRef] [PubMed]

293. Wilson, B.A.P.; Thornburg, C.C.; Henrich, C.J.; Grkovic, T.; O'Keefe, B.R. Creating and screening natural product libraries. Nat. Prod. Rep. 2020, 37, 893-918. [CrossRef] [PubMed]

294. Appleton, D.R.; Buss, A.D.; Butler, M.S. A simple method for high-throughput extract prefractionation for biological screening. Chim. Int. J. Chem. 2007, 61, 327-331. [CrossRef]

295. Tu, Y.; Jeffries, C.; Ruan, H.; Nelson, C.; Smithson, D.; Shelat, A.A.; Brown, K.M.; Li, X.-C.; Hester, J.P.; Smillie, T.; et al. Automated High-Throughput System to Fractionate Plant Natural Products for Drug Discovery. J. Nat. Prod. 2010, 73, 751-754. [CrossRef]

296. Camp, D.; Davis, R.A.; Campitelli, M.; Ebdon, J.; Quinn, R.J. Drug-like Properties: Guiding Principles for the Design of Natural Product Libraries. J. Nat. Prod. 2012, 75, 72-81. [CrossRef]

297. Nagana Gowda, G.A.; Raftery, D. Recent Advances in NMR-Based Metabolomics. Anal. Chem. 2017, 89, 490-510. [CrossRef] 
298. Wolfender, J.-L.; Nuzillard, J.-M.; van der Hooft, J.J.J.; Renault, J.-H.; Bertrand, S. Accelerating Metabolite Identification in Natural Product Research: Toward an Ideal Combination of Liquid Chromatography-High-Resolution Tandem Mass Spectrometry and NMR Profiling, in Silico Databases, and Chemometrics. Anal. Chem. 2019, 91, 704-742. [CrossRef]

299. Grienke, U.; Foster, P.A.; Zwirchmayr, J.; Tahir, A.; Rollinger, J.M.; Mikros, E. 1H NMR-MS-based heterocovariance as a drug discovery tool for fishing bioactive compounds out of a complex mixture of structural analogues. Sci. Rep. 2019, 9, 11113. [CrossRef]

300. Macarron, R.; Banks, M.N.; Bojanic, D.; Burns, D.J.; Cirovic, D.A.; Garyantes, T.; Green, D.V.S.; Hertzberg, R.P.; Janzen, W.P.; Paslay, J.W.; et al. Impact of high-throughput screening in biomedical research. Nat. Rev. Drug Discov. 2011, 10, 188-195. [CrossRef]

301. Foito, A.; Stewart, D. Metabolomics: A high-throughput screen for biochemical and bioactivity diversity in plants and crops. Curr. Pharm. Des. 2018, 24, 2043-2054. [CrossRef]

302. Paananen, J.; Fortino, V. An omics perspective on drug target discovery platforms. Brief. Bioinform. 2019. [CrossRef] [PubMed]

303. Niedzwiecki, A.; Roomi, M.W.; Kalinovsky, T.; Rath, M. Anticancer Efficacy of Polyphenols and Their Combinations. Nutrients 2016, 8, 552. [CrossRef] [PubMed]

304. Pan, Y.; Li, H.; Zheng, S.; Zhang, B.; Deng, Z. Implication of the Significance of Dietary Compatibility: Based on the Antioxidant and Anti-Inflammatory Interactions with Different Ratios of Hydrophilic and Lipophilic Antioxidants among Four Daily Agricultural Crops. J. Agric. Food Chem. 2018, 66, 7461-7474. [CrossRef] [PubMed]

305. Olszowy, M.; Dawidowicz, A.L.; Jóźwik-Dolęba, M. Are mutual interactions between antioxidants the only factors responsible for antagonistic antioxidant effect of their mixtures? Additive and antagonistic antioxidant effects in mixtures of gallic, ferulic and caffeic acids. Eur. Food Res. Technol. 2019, 245, 1473-1485. [CrossRef]

306. Bisol, Â.; de Campos, P.S.; Lamers, M.L. Flavonoids as anticancer therapies: A systematic review of clinical trials. Phyther. Res. 2020, 34, 568-582. [CrossRef]

307. Cartea, M.E.; Francisco, M.; Soengas, P.; Velasco, P. Phenolic Compounds in Brassica Vegetables. Molecules 2011, 16, 251-280. [CrossRef] [PubMed]

308. Blažević, I.; Montaut, S.; Burčul, F.; Olsen, C.E.; Burow, M.; Rollin, P.; Agerbirk, N. Glucosinolate structural diversity, identification, chemical synthesis and metabolism in plants. Phytochemistry 2020, 169, 112100. [CrossRef]

309. Farnham, M.W.; Wilson, P.E.; Stephenson, K.K.; Fahey, J.W. Genetic and environmental effects on glucosinolate content and chemoprotective potency of broccoli. Plant Breed. 2004, 123, 60-65. [CrossRef]

310. Li, B.; Xiong, M.; Zhang, H.-Y. Elucidating Polypharmacological Mechanisms of Polyphenols by Gene Module Profile Analysis. Int. J. Mol. Sci. 2014, 15, 11245-11254. [CrossRef]

311. Grynkiewicz, G. Flavonoids as a library of privileged structures-what are the gains? J. Biochem. Res. 2019, 2, 8-16.

312. Brown, K.K.; Hampton, M.B. Biological targets of isothiocyanates. Biochim. Biophys. Acta Gen. Subj. 2011, 1810, 888-894. [CrossRef] [PubMed]

313. Luesch, H.; MacMillan, J.B. Targeting and extending the eukaryotic druggable genome with natural products. Nat. Prod. Rep. 2020, 37, 744-746. [CrossRef] [PubMed]

314. Fahey, J.W.; Zhang, Y.; Talalay, P. Broccoli sprouts: An exceptionally rich source of inducers of enzymes that protect against chemical carcinogens. Proc. Natl. Acad. Sci. USA 1997, 94, 10367-10372. [CrossRef] [PubMed]

315. Houghton, C.A. Sulforaphane: Its "Coming of Age" as a Clinically Relevant Nutraceutical in the Prevention and Treatment of Chronic Disease. Oxid. Med. Cell. Longev. 2019, 2019, 2716870. [CrossRef]

316. Shapiro, T.A.; Fahey, J.W.; Wade, K.L.; Stephenson, K.K.; Talalay, P. Chemoprotective Glucosinolates and Isothiocyanates of Broccoli Sprouts. Cancer Epidemiol. Prev. Biomarkers 2001, 10, 501-508.

317. Palliyaguru, D.L.; Yuan, J.-M.; Kensler, T.W.; Fahey, J.W. Isothiocyanates: Translating the Power of Plants to People. Mol. Nutr. Food Res. 2018, 62, 1700965. [CrossRef]

318. Clulow, J.A.; Storck, E.M.; Lanyon-Hogg, T.; Kalesh, K.A.; Jones, L.H.; Tate, E.W. Competition-based\{,\} quantitative chemical proteomics in breast cancer cells identifies new target profiles for sulforaphane. Chem. Commun. 2017, 53, 5182-5185. [CrossRef]

319. Bao, Y.; Wang, W.; Zhou, Z.; Sun, C. Benefits and Risks of the Hormetic Effects of Dietary Isothiocyanates on Cancer Prevention. PLoS ONE 2014, 9, e114764. [CrossRef] 
320. Anighoro, A.; Bajorath, J.; Rastelli, G. Polypharmacology: Challenges and Opportunities in Drug Discovery. J. Med. Chem. 2014, 57, 7874-7887. [CrossRef]

321. Proschak, E.; Stark, H.; Merk, D. Polypharmacology by Design: A Medicinal Chemist's Perspective on Multitargeting Compounds. J. Med. Chem. 2019, 62, 420-444. [CrossRef]

322. Farghaly, M.M.; Abdullah, M.A.M.; Youssef, I.M.I.; Abdel-Rahim, I.R.; Abouelezz, K. Effect of feeding hydroponic barley sprouts to sheep on feed intake, nutrient digestibility, nitrogen retention, rumen fermentation and ruminal enzymes activity. Livest. Sci. 2019, 228, 31-37. [CrossRef]

323. Chantiratikul, A.; Borisuth, L.; Chinrasri, O.; Saenthaweesuk, N.; Chookhampaeng, S.; Thosaikham, W.; Sriart, N.; Chantiratikul, P. Evaluation of the toxicity of selenium from hydroponically produced selenium-enriched kale sprout in laying hens. J. Trace Elem. Med. Biol. 2016, 35, 116-121. [CrossRef] [PubMed]

324. Abouelezz, K.F.M.; Sayed, M.A.M.; Abdelnabi, M.A. Evaluation of hydroponic barley sprouts as a feed supplement for laying Japanese quail: Effects on egg production, egg quality, fertility, blood constituents, and internal organs. Anim. Feed Sci. Technol. 2019, 252, 126-135. [CrossRef]

325. Chantiratikul, A.; Chinrasri, O.; Pakmaruek, P.; Chantiratikul, P.; Thosaikham, W.; Aengwanich, W. Responses of Growing Japanese Quails that Received Selenium from Selenium Enriched Kale Sprout (Brassica oleracea var. alboglabra L.). Biol. Trace Elem. Res. 2011, 144, 760-768. [CrossRef] [PubMed]

326. Chinrasri, O.; Chantiratikul, P.; Maneetong, S.; Chookhampaeng, S.; Chantiratikul, A. Productivity and Selenium Concentrations in Egg and Tissue of Laying Quails Fed Selenium from Hydroponically Produced Selenium-Enriched Kale Sprout (Brassica oleracea var. alboglabra L.). Biol. Trace Elem. Res. 2013, 155, 381-386. [CrossRef]

327. Mattioli, S.; Dal Bosco, A.; Martino, M.; Ruggeri, S.; Marconi, O.; Sileoni, V.; Falcinelli, B.; Castellini, C.; Benincasa, P. Alfalfa and flax sprouts supplementation enriches the content of bioactive compounds and lowers the cholesterol in hen egg. J. Funct. Foods 2016, 22, 454-462. [CrossRef]

328. Chantiratikul, A.; Chinrasri, O.; Chantiratikul, P. Effect of Selenium from Selenium-Enriched Kale Sprout Versus Other Selenium Sources on Productivity and Selenium Concentrations in Egg and Tissue of Laying Hens. Biol. Trace Elem. Res. 2018, 182, 105-110. [CrossRef]

329. Dal Bosco, A.; Castellini, C.; Martino, M.; Mattioli, S.; Marconi, O.; Sileoni, V.; Ruggeri, S.; Tei, F.; Benincasa, P. The effect of dietary alfalfa and flax sprouts on rabbit meat antioxidant content, lipid oxidation and fatty acid composition. Meat Sci. 2015, 106, 31-37. [CrossRef]

330. Mohsen, M.K.; Abdel-Raouf, E.M.; Gaafar, H.M.A.; Yousif, A.M. Nutritional evaluation of sprouted barley grains on agricultural by-products on performance of growing New Zealand white rabbits. Nat. Sci. 2015, $13,35-45$.

331. Al-Saadi, M.J.; Al-Zubiadi, I.A.H. Effects of substitution barley by $10 \%, 30 \%$ of sprouted barley on rumen characters, digestibility and feed efficiency in diet of awassi male lambs. Int. J. Sci. Res. 2016, 5, 2228-2233.

332. Helal, H.G. Productive and reproductive performance of Barki ewes fed on sprouted barley grains on desert by-products during lactating period. Res. J. Anim. Vet. Sci. 2018, 10, 37-48.

333. North, M.K.; Dalle Zotte, A.; Hoffman, L.C. The use of dietary flavonoids in meat production: A review. Anim. Feed Sci. Technol. 2019, 257, 114291. [CrossRef]

334. Di Cerbo, A.; Morales-Medina, J.C.; Palmieri, B.; Pezzuto, F.; Cocco, R.; Flores, G.; Iannitti, T. Functional foods in pet nutrition: Focus on dogs and cats. Res. Vet. Sci. 2017, 112, 161-166. [CrossRef]

335. Bol, S.; Caspers, J.; Buckingham, L.; Anderson-Shelton, G.D.; Ridgway, C.; Buffington, C.A.T.; Schulz, S.; Bunnik, E.M. Responsiveness of cats (Felidae) to silver vine (Actinidia polygama), Tatarian honeysuckle (Lonicera tatarica), valerian (Valeriana officinalis) and catnip (Nepeta cataria). BMC Vet. Res. 2017, 13, 70. [CrossRef] [PubMed]

336. Van Huis, A. Prospects of insects as food and feed. Org. Agric. 2020, 1-8. [CrossRef]

(C) 2020 by the authors. Licensee MDPI, Basel, Switzerland. This article is an open access article distributed under the terms and conditions of the Creative Commons Attribution (CC BY) license (http://creativecommons.org/licenses/by/4.0/). 